\title{
A GESTÃO DE COMPETÊNCIAS EM UMA EMPRESA DE PESQUISA E DESENVOLVIMENTO
}

Dissertação apresentada à Escola de Engenharia de São Carlos da Universidade de São Paulo como parte dos requisitos para a obtenção do Título de Mestre em Engenharia de Produção.

Orientador: Prof. Dr. Fernando César Almada Santos

SÃO CARLOS

2003 
À minha mãe, Pelo exemplo de força e sabedoria. 


\section{AGRADECIMENTOS}

Aos meus pais, Carlos e Elza, pelo carinho e pelo apoio para realizar este trabalho;

À minha irmã Marisa, pelo conforto "psicológico" e afetivo.

À minha família, avós, tias, tios e primas, pelo incentivo e pelas orações.

Ao meu orientador, Fernando César Almada Santos, por toda sua dedicação, conhecimento, paciência e amizade;

À minha segunda família, meus grandes companheiros de trabalho, que me possibilitaram aproveitar essa oportunidade. Agradeço de coração cada um: Romilda, Milton, Josival, Márcia, Tadeu, Menegasso, Wilson, Gilberto, Marco Polo, Luciana, Helen, Lê, Jorge, Ricardo, Ângelo, Zé, Maria Lúcia, Chiva, Carmen, Élita, Adamaris, Rosana e Neto;

À empresa pesquisada e a todos os empregados da Embrapa Pecuária Sudeste que colaboraram com a execução do estudo de caso;

Ao pessoal do Setor de Recursos Humanos da Embrapa Pecuária Sudeste, Cássia Mazzari, Sonise, Silvia e Leandro, por toda a enorme colaboração, atenção, presteza e amizade, e principalmente, por ter acreditado e incentivado a pesquisa.

Aos funcionários da Biblioteca Central da EESC/USP, pela atenção e amizade;

Aos professores, funcionários e colegas da pós-graduação da Engenharia de Produção da EESC/USP pela colaboração;

A todos os meus amigos. 


\section{SUMÁRIO}

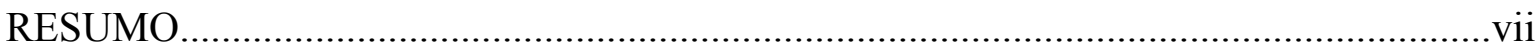

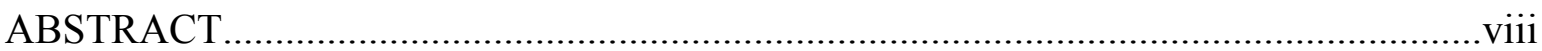

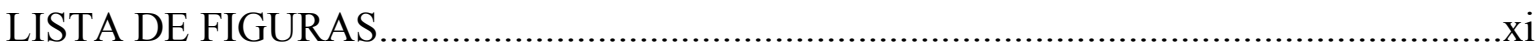

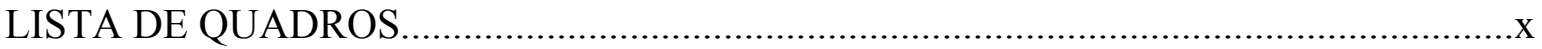

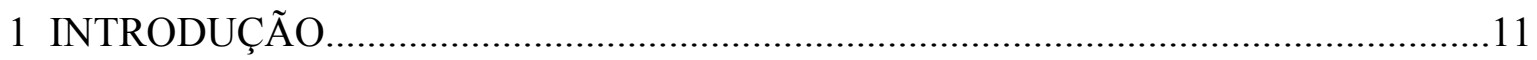

1.1 Formulação do problema....................................................................................... 12

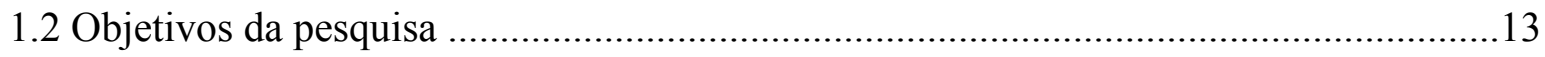

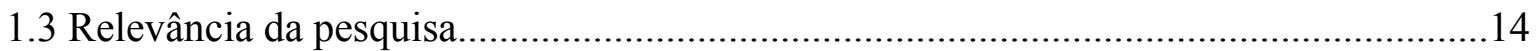

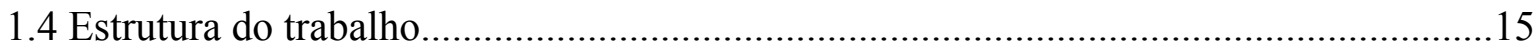

2 MUDANÇAS ORGANIZACIONAIS E GESTÃO DE RECURSOS

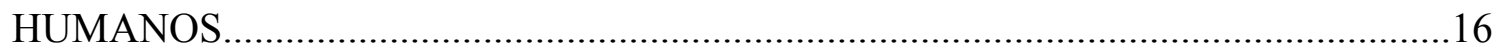

2.1 Considerações sobre mudanças organizacionais.............................................................16

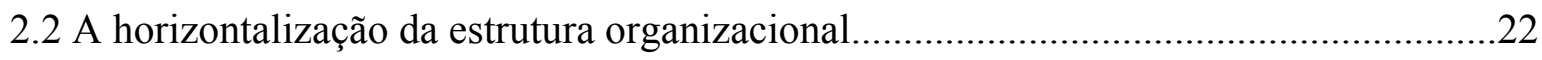

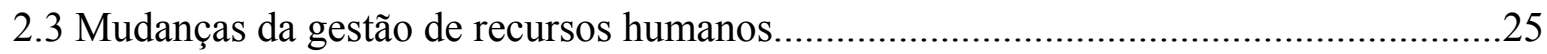

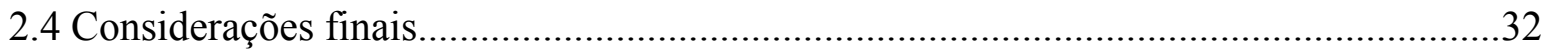

3 A EVOLUÇÃO DA GESTÃO DE COMPETÊNCIAS....................................................

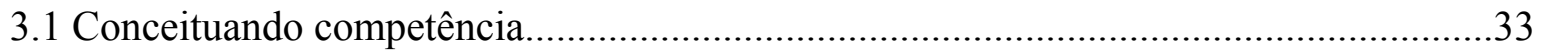

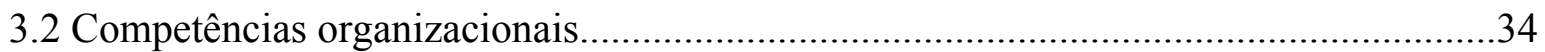




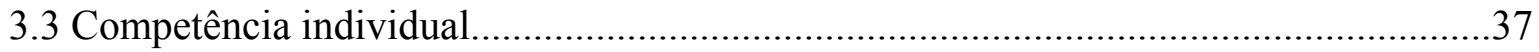

3.4 Competência e desempenho humano..........................................................................42

3.5 A gestão de competências..................................................... 48

3.6 Gestão de competências e subsistemas de recursos humanos..........................53

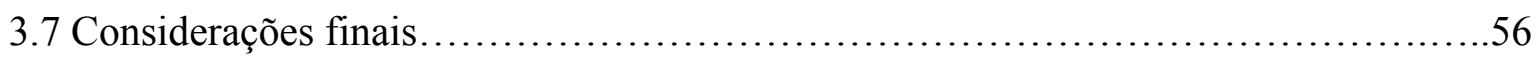

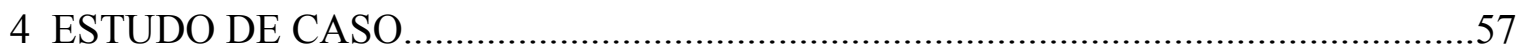

4.1 Metodologia de pesquisa.....................................................................................57

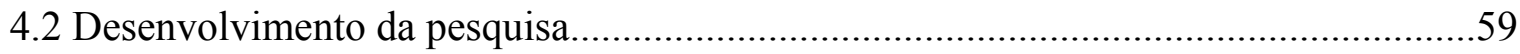

4.2.1 Empresa Brasileira de Pesquisa Agropecuária.............................................................59

4.2.2 O centro de pesquisa: Embrapa Pecuária Sudeste .......................................................64

4.2.3 Mudanças organizacionais ocorridas na Embrapa......................................................67

4.2.4 A estrutura organizacional da Embrapa......................................71

4.2.5 A gestão de recursos humanos na Embrapa............................................................73

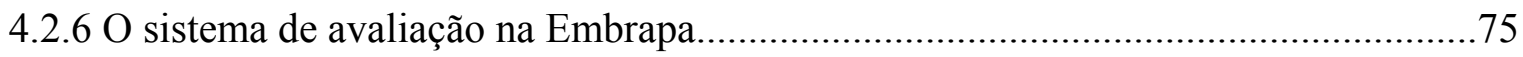

4.2.7 O sistema de planejamento, acompanhamento e avaliação de resultados e do

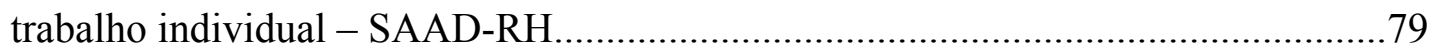

4.2.8 O SAAD e a gestão de competências..........................................................................84

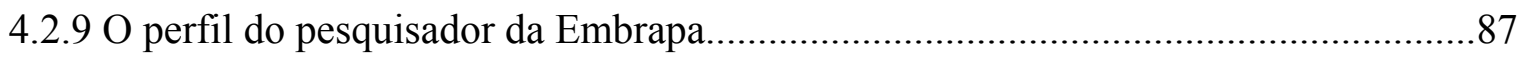

4.3 Considerações Finais............................................................................................90

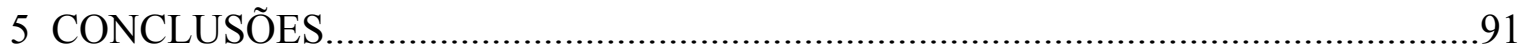

5.1 Particularidades da gestão de competências da Embrapa..............................................91

5.2 Fatores que contribuíram para gestão de competências da Embrapa............................92 
5.3 Limitações da gestão de competências da Embrapa................................................93

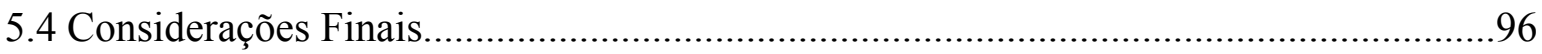

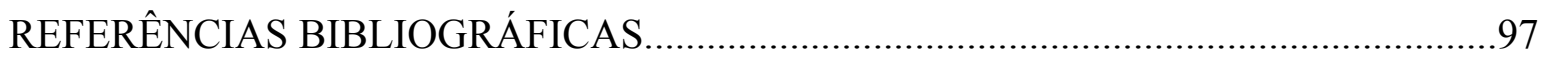

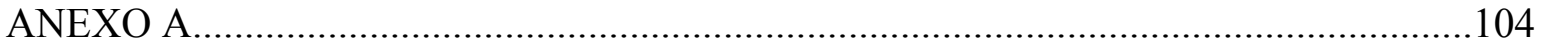

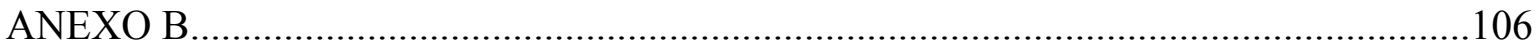

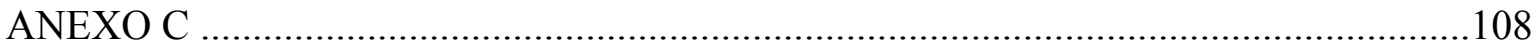

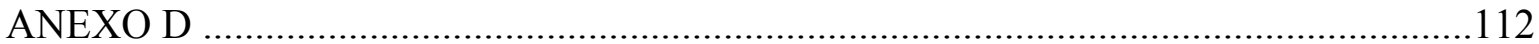




\section{RESUMO}

UBEDA, C. L. (2003). A gestão de competências em uma empresa de pesquisa e desenvolvimento: um estudo de caso. São Carlos, 2003, 117 p. Dissertação (Mestrado) Escola de Engenharia de São Carlos, Universidade de São Paulo.

A gestão de competências possibilita o aumento do desempenho global da organização através da identificação e desenvolvimento das competências individuais. O objetivo principal deste trabalho é analisar a gestão de competências em uma empresa de pesquisa e desenvolvimento. Faz-se uma revisão bibliográfica sobre a evolução das mudanças organizacionais, sobre a gestão estratégica de recursos humanos e sobre os conceitos de competência e desempenho humano. Apresenta-se o estudo de caso na Embrapa Pecuária Sudeste, centro de pesquisa agropecuária, localizado na cidade São Carlos, a fim de ampliar a compreensão dos aspectos relacionados ao desenvolvimento de competências, à formulação de estratégias e à avaliação de desempenho. Nas conclusões, discutem-se as particularidades, os fatores favoráveis e as limitações da gestão de competências na Embrapa.

Palavras-chave: competências organizacionais, competências individuais, avaliação de desempenho, gestão de competências e estratégias empresariais. 


\section{ABSTRACT}

UBEDA, C. L. (2003). The competence management on one research and development organization: a study of case. São Carlos, 2003, 117 p. Dissertação (Mestrado) - Escola de Engenharia de São Carlos, Universidade de São Paulo.

The management of competence enables the increasing performance of the whole organization through identification and development of individual competencies. The aim of this work is to analyze the management of competence in a research and development organization. The bibliography review includes the evolution of the organizational changes, the human resource strategic management and the concepts of competence and performance. A case study is carried out at Embrapa Pecuária Sudeste, agricultural research center, located in São Carlos town, in order to enlarge the comprehension of the aspects related to the development of competences, the formulation of strategies and the performance evaluation. In the section of conclusions, the peculiarities, the favorable aspects and the limitations of the management competence are discussed.

Key-words: organization competences, individual competencies, performance evaluation and company strategies. 


\section{LISTA DE FIGURAS}

FIGURA 1 - Principais etapas do trabalho e capítulos associados

FIGURA 2 - A dinâmica do desempenho pela perspectiva da evolução do pensamento administrativo

FIGURA 3 - Construção das competências e da estratégia por meio da aprendizagem.......31

FIGURA 4 - A definição de core compentence.

FIGURA 5 - O conceito de competência individual segundo HIPÓLITO (2001)

FIGURA 6 - O conceito de competência individual segundo SVEIBY (1998).

FIGURA 7 - As três dimensões da avaliação de desempenho

FIGURA 8 - Abordagem estratégica da gestão de desempenho. .46

FIGURA 9 - O ciclo da formação de competências. .50

FIGURA 10 - Estrutura necessária para a tradução da estratégia em termos operacionais.52

FIGURA 11 - Organograma do Centro de Pesquisa Embrapa Pecuária Sudeste. .66

FIGURA 12 - Modelo de Gestão Estratégica Corporativo da Embrapa

FIGURA 13 - Processo de gestão estratégica do desempenho na Embrapa....... .82 


\section{LISTA DE QUADROS}

QUADRO 1 - Mudanças na gestão de recursos humanos.......................................................27

QUADRO 2 - Estágios da gestão de recursos humanos..........................................................30

QUADRO 3 - A evolução da gestão de desempenho..............................................................46

QUADRO 4 - Cenários organizacionais da Embrapa..........................................................69

QUADRO 5 - Descrição de carreiras e cargos na Embrapa...................................................72

QUADRO 6 - Mudanças na gestão de recursos humanos.....................................................75

QUADRO 7 - Histórico da avaliação de desempenho da Embrapa.......................................78

QUADRO 8 - Elementos da gestão de competências na Embrapa.......................................95 


\section{INTRODUÇÃO}

O cenário competitivo contemporâneo tem sido regido pela globalização dos mercados, pela inovação tecnológica e pela concorrência acirrada por baixos preços e alta qualidade, a fim de atender rápida e eficientemente o consumidor final.

A volatilidade e a virtualidade erodiram as relações pessoais. A volatilidade gera oportunidade, para cada empresa destruída por uma nova tecnologia, uma nova nasce. A virtualidade dá flexibilidade aos empregados, dando as empresas uma vantagem competitiva frente à concorrência (PRUSAK e COHEN, 2001, p.88).

É preciso construir uma força de trabalho que tenha habilidade para conseguir êxito competitivo e que não possa ser prontamente copiada por outros. Isso é obtido através de práticas de recrutamento e treinamento e, de cultura focada nos resultados traçados (PFEFFER, 1994, p.22).

A autonomia de funcionários, em equipes autogerenciadas, depende da existência de pessoas que não sejam apenas dotadas de poder para fazer mudanças e aperfeiçoamentos em produtos e processos mas, também, tenham competências necessárias para fazer tal coisa inserida no contexto da organização. Recrutar, desenvolver e promover oportunidades de carreira para pessoas capazes de gerenciar inovações parece ser a principal lacuna nas estratégias das empresas (PFEFFER, 1994, p.48).

As empresas têm aumentado sua preocupação com essa lacuna de gerenciamento de seus recursos humanos. Dessa forma, para compreender adequadamente as técnicas do gerenciamento de recursos humanos torna-se necessário compreender as bases sobre as quais ela trabalha: as organizações e as pessoas.

Há várias abordagens de gerenciamento de recursos humanos que divergem quanto ao grau de controle no trabalho e ao grau de comprometimento do pessoal que desempenha 
o trabalho. No entanto, cada abordagem acrescentou nova perspectiva no gerenciamento de recursos humanos (SLACK et.al. , 1997, p.311).

Todas essas abordagens contribuíram para a evolução da gestão de recursos humanos, que atualmente é pautada pela administração participativa, acrescentando responsabilidades às tarefas e, permitindo ao empregado, realização profissional e pessoal.

No que se refere à administração estratégica de negócios, a gestão de competências é um instrumento importante que objetiva identificar as competências individuais disponíveis para melhor "aproveitá-las", através da avaliação de desempenho conjunta em todos os níveis da organização.

Com a identificação das competências individuais necessárias de cada operação a empresa pode identificar potenciais inovadores, formar e gerenciar seus recursos humanos através da mudança de postura quanto ao recrutamento, remuneração, treinamento e desenvolvimento de carreiras.

\subsection{FORMULAÇÃO DO PROBLEMA}

Trabalhar competitivamente implica valorizar pessoas, considerando suas idéias, sugestões e preferências. O conceito de participação implica trabalhadores e gerentes discutindo, conjuntamente, os rumos da empresa, organizando, para tanto, suas áreas e atividades.

Estabelecer a participação dos trabalhadores é criar oportunidade de oferecer às pessoas uma perspectiva coletiva a respeito do significado de sua prática profissional e uma maneira de se situarem no futuro. 
Em décadas anteriores, os trabalhadores e suas qualificações estavam associados somente ao cargo exercido. Eram esquecidos seus conhecimentos técnicos, suas experiências e suas habilidades, que hoje, podem-se conceituar como competências individuais.

Atualmente, com vistas à competitividade e à produtividade, cabe à organização criar condições adequadas de trabalho, oportunidade de treinamento e desenvolvimento, além da remuneração aliada a resultados.

É justamente neste ponto que a gestão de competências é muito importante para as estratégias de inovação, porque a identificação de competências em todos os níveis da organização através da avaliação dos resultados obtidos permite a melhoria das atividades e das técnicas empregadas na produção.

Não só as práticas de produção melhoram, como há também o aprimoramento da gestão de recursos humanos, com a inclusão de planos de carreiras, processos de treinamento e desenvolvimento, e remuneração variável, graças ao feedback das avaliações de desempenho feitas na organização.

\subsection{OBJETIVO DA PESQUISA}

O objetivo principal dessa pesquisa é analisar a gestão de competências em uma empresa de pesquisa e desenvolvimento.

Os objetivos secundários:

Descrever historicamente problemas relacionados à gestão de estratégias de recursos humanos; 
Discutir especificamente os conceitos de competência organizacional, de competência individual e de desempenho;

Descrever a avaliação de desempenho desenvolvida na Embrapa Pecuária Sudeste como instrumento da gestão de competências.

\subsection{RELEVÂNCIA DA PESQUISA}

Segundo Aquino (1980), o gerenciamento de recursos humanos tem um papel preponderante, na formulação e na execução do plano estratégico da empresa ao definir políticas e estratégias específicas, como o desenvolvimento de produtos e inovação, em sintonia com estratégias gerais.

As competências individuais podem transformar a capacidade potencial da empresa em capacidade real, melhorando a maneira de executar suas tarefas e, conseqüentemente, contribuindo com as outras tarefas da organização.

Designar às pessoas autoridade para fazer sugestões e mudanças no trabalho é uma atribuição dos gestores, que adotam um estilo gerencial participativo, incluindo no processo de tomada de decisão a contribuição dos recursos humanos diretamente ligados às tarefas.

Neste contexto, a gestão de competências possibilita a identificação das carências, referentes aos recursos humanos que implicam a geração de idéias e a eficiência dos projetos de pesquisa e desenvolvimento, enfim, o alcance das metas e os objetivos estratégicos da empresa. 


\subsection{ESTRUTURA DO TRABALHO}

O presente trabalho apresenta a estrutura relatada na Figura 1, e conta com revisão bibliográfica sobre a evolução das mudanças organizacionais e sobre a gestão estratégica de recursos humanos para embasar futura discussão dos seguintes conceitos: competência organizacional, competência individual, desempenho e estratégia de inovação.

PRINCIPAIS ETAPAS DO TRABALHO

\section{CAPÍTULOS ASSOCIADOS}

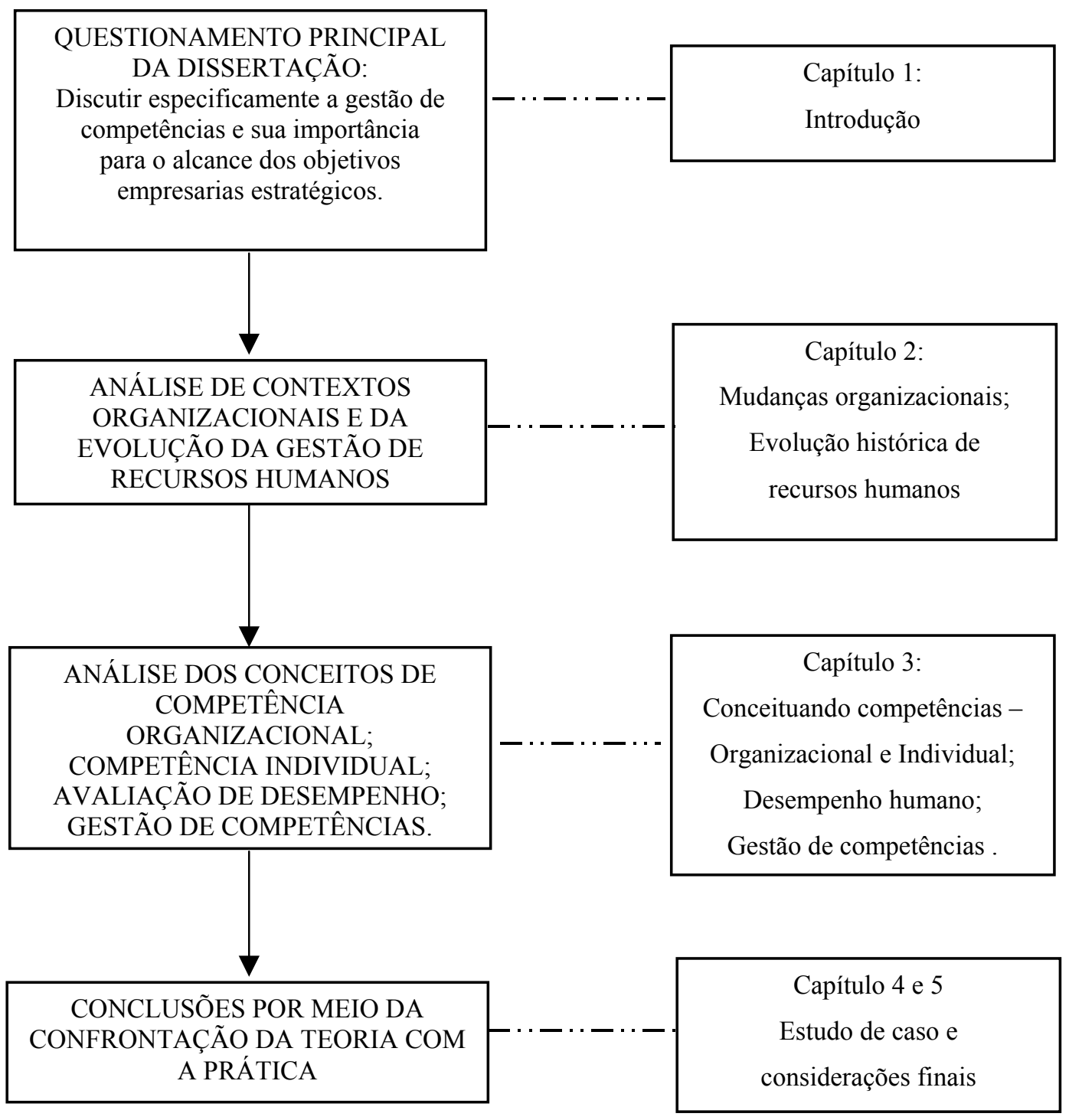

Figura 1 - Principais etapas do trabalho e capítulos associados 


\section{MUDANÇAS ORGANIZACIONAIS E GESTÃO DE RECURSOS HUMANOS}

Este capítulo apresenta uma revisão bibliográfica sobre as mudanças organizacionais mais recentes, uma vez que, as principais abordagens administrativas ajudam a entender o contexto em que se está trabalhando e, a sistematizar as idéias e os conceitos sobre recursos humanos, competências e desempenho.

\subsection{CONSIDERAÇÕES SOBRE MUDANÇAS ORGANIZACIONAIS}

"Mudança organizacional é qualquer transformação de natureza estrutural, estratégica, cultural, tecnológica, humana ou de qualquer outro componente capaz de gerar impacto em partes ou no conjunto da organização" (WOOD JUNIOR, 1995, p.190). Portanto, uma mudança pode ser classificada quanto à natureza, ao ambiente e à forma de implementação.

As mudanças organizacionais quanto à natureza estão relacionadas a qualquer característica da organização, tais como:

organograma, funções, tarefas;

> mudanças estratégicas, mercados-alvo, foco;

$>$ mudanças culturais, valores, estilo de liderança;

$>$ mudanças tecnológicas, processos e métodos de produção;

$>$ mudanças de pessoal, políticas de seleção e formação.

As mudanças organizacionais relacionadas com o ambiente podem ser:

> reativa, uma resposta a mudanças nele ocorridas;

> voluntária, uma antecipação baseada em expectativas. 
As mudanças organizacionais quanto à forma de implementação podem ser:

re-educativa, transmitindo novos conhecimentos;

coercitiva, impondo respeito por normas;

$>$ ou racional, busca da eficiência.

As organizações sempre se preocuparam com as técnicas administrativas e as mudanças organizacionais, inclusive antes da Revolução Industrial. Bons exemplos disso são: a administração pública do Egito, Grécia ou China, as estratégias dos militares romanos e as idéias de Maquiavel (CANÊDO, 1987).

A teoria administrativa, através das organizações, busca trabalhar com e através de pessoas, em busca de resultados. Tornou-se mais evidente e estruturada depois da Revolução Industrial, refletindo o contexto e os valores sociais da época. Nos dias atuais, a sociedade moderna se caracteriza pela existência das organizações regidas pelo princípio da eficiência e pela busca de resultados (CANÊDO, 1987).

Tal fato, mostra que a teoria administrativa sempre se preocupou em monitorar os impactos das mudanças organizacionais e que o administrador, um especialista em agregar pessoas, conduz para a obtenção do objetivo da organização e delas próprias, usando os recursos disponíveis da melhor forma possível, isto é, buscando a eficácia e a eficiência.

O que a teoria clássica da administração propôs foi uma ruptura com a tradição e os sistemas familiares não organizados, principalmente introduziu o conceito da eficiência e do uso da razão. Dentre os seus principais representantes, Taylor (1916) preocupou-se com os métodos e processos de trabalho operário, the best way e the best man, rendimento máximo, divisão de tarefas entre supervisores e trabalhadores. Além disso, elegeu quatro princípios: "tornar a administração uma ciência, seleção científica, treinamento cientifico e cooperação harmoniosa entre trabalhador e gerência" (PARKER et.al., 1997). 
Para Wood Junior (1995), o início do ciclo de produção capitalista caracterizou-se, fundamentalmente, pela separação do trabalhador dos meios de produção, indicando o surgimento das grandes fábricas e das linhas de montagem contínua que aceleraram as mudanças, alterando radicalmente os sistemas organizacionais.

Ainda hoje, muitas indústrias, ou mesmo unidades ou departamentos, encontram na administração científica uma resposta para seus problemas, pressupondo condições estáveis, produtos com poucas mudanças e previsibilidade do fator humano (WOOD JUNIOR, 1995, p.97).

A administração científica procura aperfeiçoar em seus empregados, durante a seleção e treinamento, as habilidades necessárias para o exercício de atividades específicas, restringindo-se apenas às questões técnicas relacionadas ao trabalho e às especificações do cargo.

No entanto, em decorrência de pressões sociais e do aumento da complexidade das relações de trabalho, as organizações passaram a considerar, também aspectos sociais e comportamentais relacionados ao trabalho no processo de desenvolvimento profissional, tais como a interação entre equipes e o contexto organizacional interno e externo.

Para Fleury e Fleury (2000, p.64), a década de 90 destacou-se pelo alinhamento das políticas de gestão de recursos humanos às estratégias empresariais, incorporando à prática organizacional o conceito de competência, como base do modelo para se gerenciar pessoas.

Com base na evolução histórica da teoria administrativa, Morgan (1996, p.16) desenvolve algumas metáforas para a compreensão das mudanças organizacionais ao longo do tempo. Usar uma metáfora implica, segundo o autor, um modo de pensar e uma forma de ver que permeia a maneira pela qual entendem-se as organizações e o mundo em geral.

Uma das metáforas refere-se à organização como máquina. Os administradores pensam as organizações como máquinas e tendem a administrá-las e planejá-las como 
"partes" que se interligam, cada uma desempenhando um papel claramente definido por normas e regulamentos que definem o funcionamento do todo (MORGAN, 1996, p.17).

Wood Junior (1995, p.23) ressalta que como as máquinas rotinizam a produção, a burocracia rotiniza a administração. A organização mecanicista ou burocrática enfatiza a precisão, a velocidade, a clareza, a confiabilidade e a eficiência atingidas através da divisão rígida de tarefas, da supervisão hierárquica e de regras e regulamentos detalhados

A metáfora da organização como organismos está ligada à Escola de Relações Humanas, à Teoria dos Sistemas, à Teoria da Contingência e à Visão da Ecologia Organizacional. Enfoca as relações entre organização e seu meio, a importância da inovação e a questão da sobrevivência como objetivo central e a busca da harmonia entre a estratégia, a estrutura, a tecnologia e as dimensões humanas (WOOD JUNIOR, 1995, p.101).

A metáfora da organização como cérebro enfoca a importância do processamento de informações, aprendizagem e inteligência. Morgan (1996) menciona duas imagens: um sistema de processamento de informações e um holograma, para elucidar o impacto da informatização e entender o todo em cada parte, criar conectividade e redundância, gerar simultaneamente especialização e generalização e, criar capacidade de auto-organização.

De acordo com Wood Junior (1995, p.109), um projeto organizacional com características holográficas deve adotar quatro princípios: fazer o todo em cada parte, criar conectividade e redundância, criar simultaneamente especialização e generalização e criar capacidade de auto-organização.

Com base em Herzog ${ }^{1}$, Wood Junior (1995, p.191) classifica em três categorias as situações capazes de provocar mudanças nas organizações, apresentando cada uma delas com três possibilidades:

\footnotetext{
${ }^{1}$ HERZOG, J.P. People the critical factor in managing change. Journal of systems management, Cleveland, v.43, n.3, p.6-11, mar., 1991 apud WOOD JUNIOR, T. (Coord.) (1995). Mudança organizacional: aprofundando temas atuais em administração de empresas. São Paulo: Atlas.
} 
nas crises e problemas, destacam-se dificuldades com a estrutura organizacional, incapacidade de atender às necessidades dos clientes e restrição de recursos;

nas novas oportunidades, as possibilidades são introdução de novas tecnologias, introdução de novos produtos e serviços, e disponibilidade de novos recursos;

> nas novas diretrizes internas ou externas, presenciam-se adequação a novas leis, adaptação a novas estratégias corporativas e implementação de novos sistemas de controle.

Em questão de mudança organizacional, os modismos se sucedem (Total Quality Management - TQM, Reengenharia, Mudança de cultura, etc.). No entanto, a forte tendência é a superação dos modelos hierárquicos de organização - com sua rigidez e tarefas centradas no indivíduo pelos sistemas mais flexíveis em que imperam a participação e os processos decisórios consensuais grupais. Dessa forma, o controle coercitivo dá lugar ao controle através da cultura organizacional (WOOD JUNIOR, 1995, p.171).

A evolução do pensamento administrativo evidencia que a atividade administrativa e a formulação de teorias são altamente dinâmicas, e não se tem receita certa. Há diferentes formas de se olhar à organização e de se preocupar com o desempenho humano, que podem ser mais ou menos abrangentes, como visualizado na Figura 2.
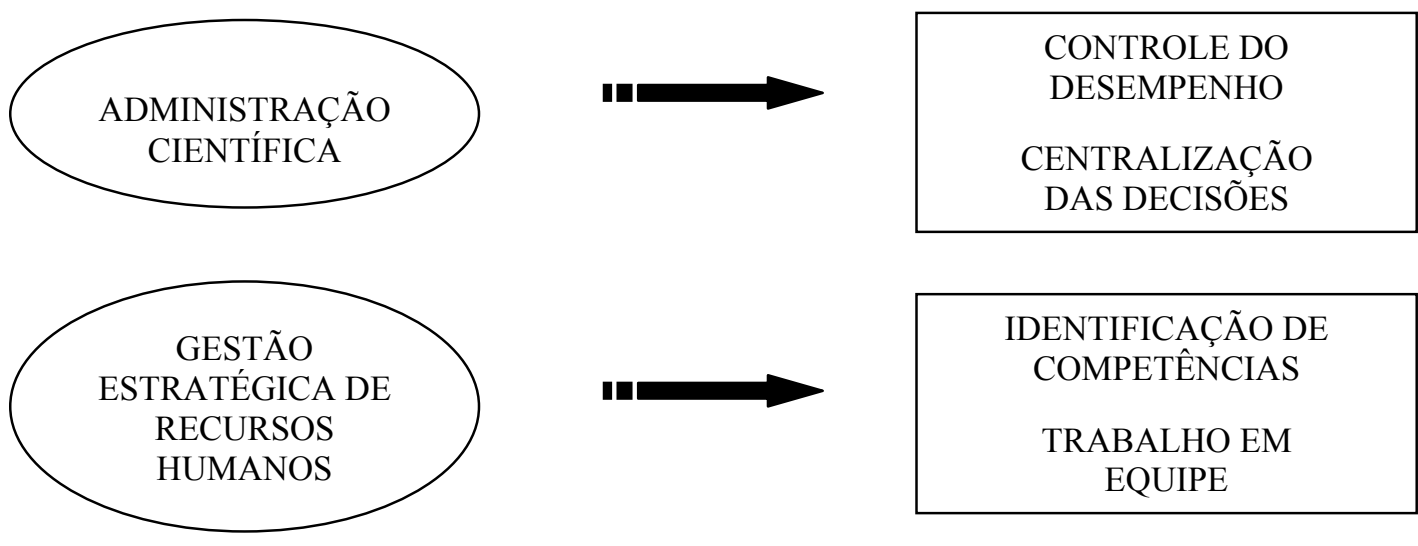

\section{IDENTIFICAÇÃO DE \\ COMPETÊNCIAS \\ TRABALHO EM EQUIPE}

Figura -2 A dinâmica do desempenho pela perspectiva da evolução do pensamento administrativo. 
A atividade administrativa é uma atividade grupal, em que o comportamento requer não só a tomada de decisões, mas também, a aceitação da mesma decisão por todos os membros do grupo, através do exercício de autoridade ou de influenciação.

O desempenho da organização é influenciado pelas competências dos seus funcionários. A competência humana aliada a outros recursos empresariais, dá origem e sustentação à competência organizacional. A participação dos funcionários no processo de gestão de competências, expondo suas expectativas, motivações e também percepções a respeito de seu superior e da estratégia de negócios da empresa é fundamental para o sucesso empresarial.

Segundo Nadler e Tushman (1994, p.44), a função primordial da alta gerência é projetar, construir e operar organizações que funcionem eficientemente, porque a organização tem como principal objetivo ser um mecanismo econômico criado para alcançar resultados que não poderiam ser alcançados por indivíduos que trabalhassem isoladamente.

Num contexto de sistema aberto, organizações interagindo com seu ambiente, os três desafios dos administradores são:

$>$ adequação estratégica ou a tomada de decisões estratégicas eficientes e adequadas que permitam a organização reagir às exigências, limitações e oportunidades apresentadas pelo ambiente;

adequação estratégia-organização referente à arquitetura organizacional correspondente à estratégia do negócio;

adequação da organização interna através da congruência entre os componentes da organização - trabalho, pessoal, organização formal e organização informal. 
Entende-se que com a globalização e a concorrência acirrada, as organizações têm buscado uma maior flexibilidade para adaptarem-se a dinâmica das mudanças. Pode-se afirmar, ainda, que há uma preocupação com a estratégia e a identificação das competências organizacionais e individuais para obtenção de vantagem competitiva pela empresa.

\subsection{A HORIZONTALIZAÇÃO DA ESTRUTURA ORGANIZACIONAL}

Discute-se a estrutura organizacional, como uma rede de tarefas, para se implementar estratégias e obter vantagens competitivas num futuro previsível, proporcionando trabalho cooperativo em alianças.

A estrutura organizacional definida como o conjunto de redes de tarefas, estabelece hierarquia de comando do trabalho e de comunicação entre indivíduos e grupos.

Para Hampton (1996), a estrutura é a ferramenta que um administrador pode usar para que a organização prossiga na execução de sua estratégia, adaptando-se às novas tecnologias e a seu ambiente. Uma vez que formaliza o poder, diferencia as atividades e determina responsabilidades e autoridade, facilitando a comunicação e o controle, bem como, a tomada de decisão.

Ao acompanhar a gestão empresarial, a estrutura organizacional se transforma; realinhando seus processos, suas competências e seus sistemas de informação com os objetivos estratégicos da empresa. Evidencia-se o achatamento da hierarquia e a eliminação dos cargos, diminuindo o gerenciamento hierárquico, graças à tecnologia de informação que proporciona o desenvolvimento de equipes auto-geridas e o envolvimento dos funcionários nos processos. 
O contexto atual requer tanto um maior uso da criatividade e da inovação para a tomada de decisão, como a capacitação constante do gerente para liderar a mudança planejada selecionando os alvos adequados para a mudança (estrutura, tarefas, pessoas e/ou cultura).

A estrutura está diretamente ligada ao desempenho organizacional uma vez que, proporciona ao gerente a autoridade e o poder necessários para o alcance das metas traçadas. $\mathrm{O}$ gerente eficaz influencia as outras pessoas a trabalharem entusiasticamente em prol dos objetivos organizacionais, sendo o poder um ingrediente essencial para a liderança eficaz, ou seja, é a habilidade para conseguir que os outros façam aquilo que você quer que eles façam.

Assim, a estrutura de uma organização reflete a maneira como o trabalho é dividido em tarefas distintas e como é feita a coordenação entre essas tarefas. À proporção que o trabalho organizacional muda e vai se tornando mais complexo, a estrutura também é forçada a "aprimorar-se", como que uma "evolução". Um artesão, por exemplo, trabalhando sozinho, não tem coordenação externa, segue apenas suas idéias. Já quando precisa trabalhar com um ajudante, ambos passam a se relacionar informalmente a fim de coordenarem o trabalho que agora é feito conjuntamente (MINTZBERG, 1995).

Quando o trabalho passa a ser realizado por mais pessoas há a tendência para a divisão de tarefas e conseqüentemente sua padronização e rotinização, para a especificação dos resultados e para o treinamento dos empregados.

A estrutura organizacional vem sendo discutida desde a administração científica, que se preocupava principalmente com a divisão de tarefas, supervisão direta do trabalho e com a padronização dos produtos e serviços oferecidos. Várias correntes da teoria administrativa discorrem sobre a estrutura para explicar a organização e a coordenação do trabalho. 
As últimas tendências administrativas vêem a estrutura de forma mais ampla, estudam o relacionamento entre as estruturas formal e informal, com a supervisão e padronização de tarefas e resultados e, também, com o ajustamento mútuo do trabalho.

As estruturas organizacionais atuais apresentam-se bem entrelaçadas, sendo quase impossível dissociar a coordenação formal da informal, uma vez que a hierarquia e a gerência formal acabam refletindo exatamente os comportamentos que naturalmente acontecem dentro do relacionamento informal.

A adhocracia, uma estrutura orgânica de assessoria, com pouca formalização de comportamento, apoiada no treinamento, que se desdobra em pequenas equipes de projeto baseadas no mercado para levar a efeito seu trabalho, preocupa-se em ser inovativa sempre. Os gerentes tornam-se membros funcionais das equipes de projeto, com a responsabilidade especial de efetivar a coordenação entre eles, e assim, a divisão entre linha e assessoria fica praticamente nula (MINTZBERG, 1995).

As organizações eliminam níveis desnecessários de gerência, ficam mais achatadas e enxutas em busca de uma maior vantagem competitiva, e passam a trabalhar com equipes multifuncionais focadas na inovação e nas necessidades e exigências do cliente.

Graças à maior amplitude de controle do funcionário sobre as tarefas e ao empowerment, os gerentes assumem responsabilidades por um número maior de subordinados, mas com uma supervisão menos direta, porque há transferência de poder de decisão às pessoas.

Senge (1990) ressalta a importância de se repensar a hierarquia gerencial e a potencialização de redes informais, como modo de enfatizar a circulação de conhecimentos entre as pessoas da empresa. O desafio é criar organogramas que, ao mesmo tempo, mantenham a primazia funcional e integrem especialidades dos times e estruturas que operem lateralmente num sistema baseado em competências. 
Segundo Lawler III (1995), trabalhar com um sistema baseado em competências significa proporcionar uma organização mais flexível e mais focada no cliente. Evidenciase a necessidade de desenvolvimento de uma série de habilidades que sejam apropriadas e únicas para a organização e que determinarão suas competências essenciais e a vantagem competitiva da empresa.

Com base nestas considerações, observa-se que a estrutura organizacional é, então, resultado da estratégia da empresa, e segue fortes tendências em direção a poucas unidades de comando, cadeias de comando mais curtas, mais delegação e empowerment e redução de staff(RODRIGUES e SANTOS, 2001).

\subsection{MUDANÇAS DA GESTÃO DE RECURSOS HUMANOS}

A gestão de recursos humanos caminha para a gestão estratégica, enfatizando as pessoas como recurso determinante para o sucesso organizacional, uma vez que a busca pela competitividade impõe às empresas a necessidade de contar com profissionais altamente capacitados, aptos a fazerem frente às ameaças e oportunidades do mercado (BRANDÃO e GUIMARÃES, 2001; MARRAS, 2000; FLEURY e FLEURY, 2000; SANTOS, 1999; CHIAVENATTO, 1996).

A função de gestão de recursos humanos, ao longo do tempo, desloca-se da gestão centralizada na alta gerência para a gestão estratégica de negócios. Assim, passa a gerenciar a complexidade e as mudanças e, a reestruturar a organização para melhorar seu desempenho, ao mesmo tempo em que proporciona aos funcionários condições para se adequarem a esta nova gestão estratégica.

Fischer (1998, p.17) ressalta que a área de recursos humanos perdeu seu poder de monopólio sobre o comportamento humano nas empresas. Para ele, o novo "modelo de gestão de pessoas" vai muito além da estrutura, dos instrumentos e das práticas 
normatizadas de recursos humanos, abrangendo tudo aquilo que interfere de maneira significativa nas relações entre os indivíduos e a organização.

O modelo de gestão de pessoas deve ser compreendido como o conjunto de políticas, práticas, padrões atitudinais, ações e instrumentos empregados por uma empresa para interferir no comportamento humano e direcioná-lo no ambiente de trabalho. Do ponto de vista empresarial, tais iniciativas são provenientes de diferentes instâncias organizacionais e se mesclam com as estratégias e práticas dos próprios empregados (FISCHER, 1998, p.20).

No início da era industrial, como a disseminação das teorias taylorista e fordista, a utilização dos cargos era o elemento central da gestão de recursos humanos. A partir da década de 80 , os conceitos foram mudando, dadas as ferramentas do modelo japonês de produção, caracterizado pelo trabalho cooperativo e de equipe e pela falta de demarcação precisa de tarefas em cada posto de trabalho.

Baseado nesse enfoque japonês, as empresas começaram a dar mais importância aos seus funcionários e, passaram a considerá-los como recurso estratégico, contrapondo os sistemas tradicionais marcados pelo estilo burocrático de gestão, pelas decisões centralizadas na alta gerência e pelo desalinhamento com a estratégia da empresa.

Ramos (2001, p.61) aponta que sob o paradigma do taylorismo-fordismo, o conceito de qualificação esteve restrito aos diplomas e aos códigos de profissões, destacando apenas o determinismo tecnológico e conceitual. Dessa forma, sofre fortes questionamentos: o sistema de classificação de cargos e salários baseado em diplomas e carreiras bem definidas não seriam mais adequados ao cenário de instabilidade das ofertas de emprego e de gestão flexível.

A crise do emprego deteriorou o conceito de qualificação conceitual (Ramos, 2001, p.62). Novos paradigmas da gestão de recursos humanos surgiram e deslocaram o foco, antes centrado no cargo, para a competência. A gestão de desempenho passa a se concentrar 
no indivíduo e não mais na tarefa. A seleção é feita por conhecimento e não por habilidades. A remuneração deixa de ser fixa para se tornar variável, através dos programas de participação por lucro e resultados - PLR (Quadro 1).

\begin{tabular}{|c|c|c|}
\hline \multirow{2}{*}{ CONCEITOS } & DE & PARA \\
\hline Gestão de recursos humanos & Operacional & Estratégica \\
\hline Foco & Cargo & Competência \\
\hline Gestão de desempenho & Concentrada & Concentrada \\
& nas tarefas & Fo indivíduo \\
\hline Carreira & Caminho único & Multifuncionalidade \\
\hline Desenvolvimento & Especialização & Conhecimento \\
\hline Seleção & Habilidades & Participação por lucros \\
Remuneração & Fixa & \\
& & \\
\hline
\end{tabular}

Quadro 1 - Mudanças da gestão de recursos humanos

A nova concepção das políticas de gestão de recursos humanos valoriza o talento humano, o que confere maior importância à atração e à manutenção de funcionários “com potencial" e, cria condições favoráveis para a motivação e para o crescimento profissional através de incentivos vinculados aos resultados.

Neste contexto, Prusak e Cohen (2001, p.88) definem o novo perfil da gestão de recursos humanos pelo investimento no capital social de três maneiras. A primeira, fazer conexões ao demonstrar comprometimento em valorizar e reter o capital social dentro da empresa, ao mesmo tempo em que considera as pessoas como seres humanos e não apenas como fonte de recursos. A segunda, construir confiança na organização e nas suas equipes de trabalho, através de posturas gerenciais transparentes e de regras bem definidas e eqüitativas. Isto não implica complacência para gerar confiança, pois, promovendo o mérito 
individual, a organização prova que a confiança é bem sucedida. A terceira, fomentar cooperação através da diversidade de oportunidades e do trabalho em equipe, estabelecendo sempre as mesmas regras para as mesmas atividades. Nenhuma empresa produz o capital social meramente com a construção de equipes, a confiança é construída ao longo do tempo através do entendimento, do aperfeiçoamento, do conhecimento técnico e da lealdade dos empregados.

Segundo Meshoulam e Baird (1987), essa nova perspectiva em gestão de recursos humanos explica como as organizações estão mudando e como a gestão de recursos humanos pode proativamente antecipar e responder às suas necessidades. Esses autores, também, mostram a evolução da gestão de recursos humanos em quatro principais movimentos.

Durante as décadas de 60 e 70, a primeira tendência de gestão de recursos humanos sofre uma grande pressão sobre a área de pessoal, vinda de fora da organização, pela busca de iguais oportunidades, segurança e programas de responsabilidade social. A função de recursos humanos fornece serviços vitais ao negócio, mas quanto mais externamente envolvida menos ligada está com a essência da própria empresa.

Uma segunda tendência leva a função de recursos humanos para mais longe do negócio, uma profissão especializada e orientada pelo estudo de suas disciplinas. Os profissionais de recursos humanos preocupam-se apenas em fornecer programas, ferramentas e técnicas relativas às suas áreas de especialização, sem se focar nas necessidades globais do negócio.

A terceira tendência emerge quando as organizações tentam preencher a lacuna entre os gerentes de linha e os profissionais especializados da função de recursos humanos. Os gerentes de linha podem contribuir, significativamente, se interagirem com a área de recursos humanos, mas usualmente vêem suas tarefas relativas ao pessoal, prioritariamente, como pequenas e isoladas ao longo do caminho de suas carreiras, não tendo assim, um comprometimento para melhorar a gestão de recursos humanos. 
Atualmente, a última tendência indica profissionais e gerentes reconhecendo a necessidade de práticas de gestão de recursos humanos baseados no negócio (SCHULER e JACKSON, 1995). A crescente complexidade, as mudanças nas tecnologias, os altos níveis de competição e a necessidade por flexibilidade fazem das pessoas um recurso ainda mais importante.

A iniciativa por boas práticas de recursos humanos vem de dentro da organização. Para construir uma gestão estratégica de recursos humanos é necessária a compreensão tanto da missão quanto da visão da organização.

À medida que as organizações crescem e se desenvolvem, suas necessidades de gestão de recursos humanos modificam-se. Para que a gestão de recursos humanos seja efetiva é necessário que ela cresça junto com a organização. Uma adequação externa da gestão de recursos humanos deve ser mantida, ao mesmo tempo em que, os componentes internos dos programas de gestão de recursos humanos, os subsistemas e as práticas, também, consigam ser eficientemente organizados para que forneçam apoio uns aos outros (Quadro 2). 


\begin{tabular}{|c|c|}
\hline MOVIMENTO & GERENCIAMENTO DA FUNÇÃO DE RECURSOS HUMANOS \\
\hline Iniciação & Isolado, informal e freqüentemente nenhum. \\
\hline $\begin{array}{c}\text { Crescimento } \\
\text { Funcional }\end{array}$ & $\begin{array}{l}\text { Realizado pelo gerente de recursos humanos. } \\
\text { Programas direcionados ao gerenciamento do conflito entre sub-funções } \\
\text { de recursos humanos. }\end{array}$ \\
\hline $\begin{array}{l}\text { Crescimento } \\
\text { Controlado }\end{array}$ & $\begin{array}{c}\text { Realizado pelo executivo de recursos humanos. } \\
\text { Orientação pelos negócios, pelos controles, pelas medidas de } \\
\text { desempenho e metas. }\end{array}$ \\
\hline $\begin{array}{l}\text { Integração } \\
\text { Funcional }\end{array}$ & $\begin{array}{l}\text { Orientação funcional e pelas metas das unidades de negócios. } \\
\text { Planejamento de longo prazo. } \\
\text { Relações de colaboração entre linha e área de recursos humanos. }\end{array}$ \\
\hline
\end{tabular}

Quadro 2 - Estágios da gestão de recursos humanos.

Fonte: adaptado de Meshoulam e Baird (1987, p.488).

Para Meshoulam e Baird (1987), a gestão de recursos humanos está vivendo no passado. Historicamente, práticas e procedimentos que se desenvolveram a partir de experiências que respondem a pressões e necessidades das organizações, têm um caráter reativo. A função de recursos humanos, para possibilitar o sucesso das organizações, deve ser capaz de se antecipar e se preparar para as necessidades futuras do gerenciamento estratégico.

A proatividade da gestão de recursos humanos será possível quando a empresa buscar conhecer sua essência, isto é, sua verdadeira competência organizacional, 
apresentada pelas competências humanas individuais e pelos recursos disponíveis para a consecução de seus objetivos estratégicos.

Um dos importantes aspectos desta conscientização de recursos humanos no planejamento estratégico é a formação de competências. Segundo Fleury e Fleury (2000), o aumento da competitividade e da instabilidade econômica e política dos mercados têm levado as empresas a se especializarem em seu core business, criando mais competência interna (Figura 3). Desta forma, é por meio do processo de aprendizagem e de gestão do conhecimento que as organizações podem desenvolver as competências necessárias para a realização de sua estratégia competitiva.
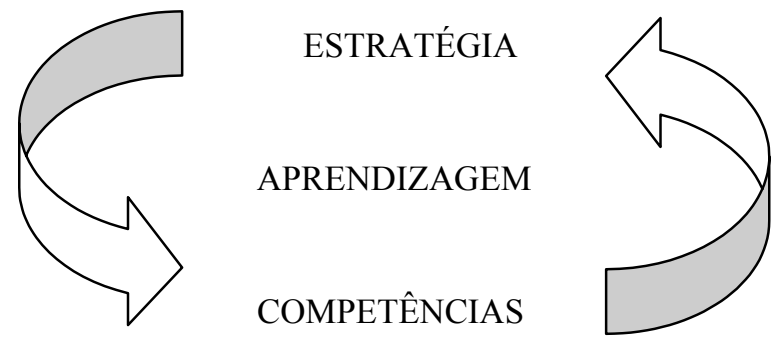

Figura 3 - Construção das competências e da estratégia por meio da aprendizagem. Fonte: Fleury e Fleury (2000, p. 17).

A gestão de recursos humanos tem papel decisivo na identificação e formação de competências, para garantir o bom desempenho dos indicadores a serem monitorados frente à formulação estratégica da organização.

Segundo Santos (1998), o redesenho dos cargos leva a organização ao gerenciamento estratégico de seus recursos humanos e a elaborar um sistema de plano de carreira baseado no indivíduo. $\mathrm{O}$ valor e o reconhecimento são dados ao funcionário e não ao cargo que ele ocupa. Há uma maior flexibilidade na alocação dos funcionários em projetos ou áreas, pois, a pessoa que possui determinados talentos é capaz de desenvolver eficientemente diferentes tarefas. 
É importante que a organização, ao gerenciar seus recursos humanos, promova a geração de novas idéias e encoraje a adoção das mesmas. A gestão de competências auxilia a organização na identificação das contribuições efetivas de cada funcionário e, possibilita sua recompensa como um incentivo à criatividade e à motivação.

Um modelo integrado de recursos humanos com a estratégia de negócios utiliza competências individuais como referência para outras funções e instrumentos de gestão de recursos humanos, apontando estratégias e mecanismos de recrutamento e seleção, treinamento e desenvolvimento, recompensa e gestão de carreiras.

Neste contexto, Dutra (2001, p.27) ressalta:

organização e pessoas, lado a lado, propiciam um processo contínuo de troca de competências. A empresa transfere seu patrimônio para as pessoas, enriquecendoas e preparando-as para enfrentar novas situações profissionais e pessoais, dentro ou fora da organização. As pessoas, por seu turno, ao desenvolver sua capacidade individual, transferem para a organização seu aprendizado, dando-lhe condições para enfrentar novos desafios.

\subsection{CONSIDERAÇÕES FINAIS}

A identificação da competência organizacional fornece ótimos subsídios para a definição das estratégias e das potencialidades da empresa, ao mesmo tempo em que viabiliza uma gestão de pessoas mais eficiente e coerente baseada na obtenção dos resultados propostos.

Desta forma, diagnósticos de competências do funcionário tornam-se inputs para a gestão de pessoas e para a implementação de avaliações de desempenho por resultados, de ações de desenvolvimento profissional e de reciclagem de processos ou políticas internas da empresa. 


\section{GESTÃO DE COMPETÊNCIAS}

Este capítulo visa esclarecer o conceito de competência e desempenho humano, define-se competência organizacional e competência individual para apresentar a gestão de competências.

\subsection{CONCEITUANDO COMPETÊNCIAS}

Competência, segundo o dicionário, vem do latim competentia, e significa a qualidade de quem é capaz de apreciar e resolver certo assunto, fazer determinada coisa, capacidade, habilidade, aptidão e idoneidade (FERREIRA, 1995, p. 353).

Ramos (2001, p.66), baseando-se em Schwartz ${ }^{2}$, destaca que a noção de competência propõe o saber-fazer proveniente da experiência ao invés de somente os saberes teóricos tradicionais valorizados na lógica da qualificação. Basicamente, desloca a atenção para a atitude, o comportamento e os saberes tácitos dos trabalhadores devido às novas concepções do trabalho baseado na flexibilidade, na autonomia, responsabilidade, capacidade de comunicação e polivalência.

Alguns autores conceituam gestão por competências e habilidades como a mesma prática da gestão estratégica de recursos humanos. Mas, De La Poza (1998, p. 24) enfatiza que competências e habilidades são conceitos diferentes, embora similares. Competências são as "tarefas diretivas ou profissionais", enquanto habilidades são utilizadas as "tarefas técnicas ou operacionais".

2 SCHWARTZ, Y. A propus du glissement sémantique "qualification-competénce": la qualification à la recherche de sés conditions aux limites. $4^{\circ}$ Journées de Sociologie du Travail. PIRTTEM-CNRS, Université de Toulouse-Le Mirail, vol.1, p. 177-199. 
A gestão de competências é uma prática de gestão que visa aumentar o desempenho global da corporação, através do incremento do desempenho individual de seus empregados. Para tanto, busca-se a identificação de fatores que levam os indivíduos a se diferenciarem quanto ao produto de seu trabalho, resultados, outputs ou de fatores relativos à formação pessoal, qualificação, inputs (CONDE, 2001, p. 63).

Conde (2001, p. 33) apresenta a questão da competência e suas diversas abordagens. Atualmente, fala-se em competências, basicamente, em duas instâncias:

uma visão macro, ligada à estratégia de negócios;

uma visão micro, ligadas aos indivíduos que trabalham nas empresas.

\subsection{COMPETENNCIAS ORGANIZACIONAIS}

Em nível amplo, Hamel e Prahalad (1990) definem o conceito de "core competence", ou competência essencial, como um conjunto de habilidades, competências e tecnologias que permite uma empresa atender necessidades específicas de seus clientes, isto é, alcançarem vantagem competitiva sobre seus concorrentes (Figura 4).

Assim, a competência essencial da empresa é a soma do aprendizado de todo o conjunto de suas habilidades e competências individuais nos processos decisórios da organização. Constitui uma fonte de vantagem competitiva, porque deve ser única e contribuir para o valor percebido pelo cliente e não ser, facilmente, copiada pela concorrência. 


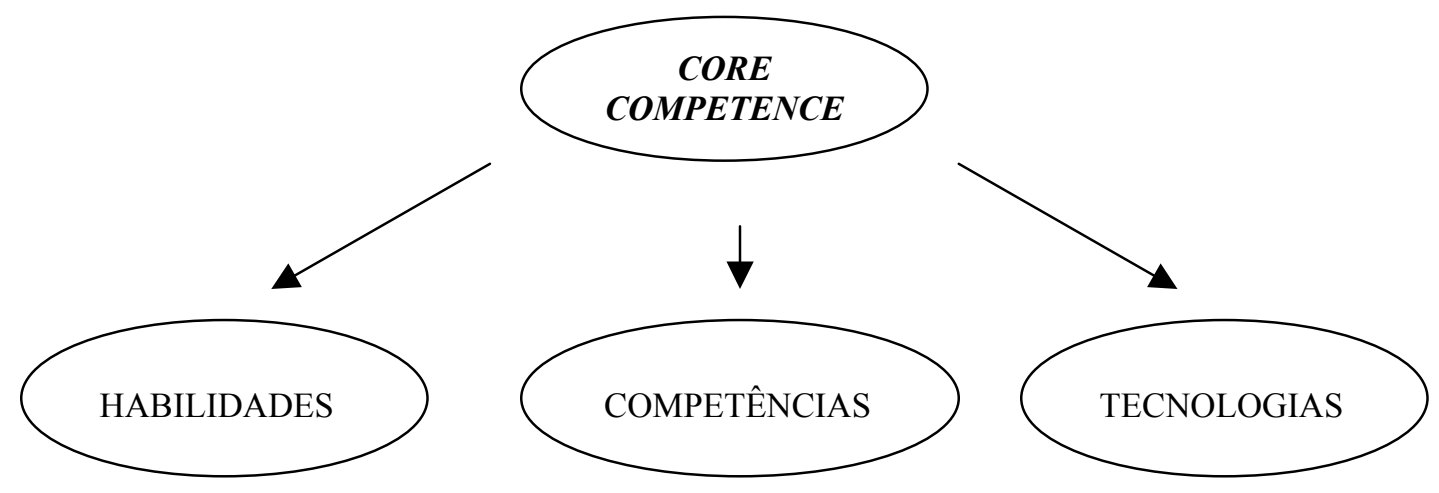

Figura 4 - A definição de core competence.

Fonte: Hamel e Prahalad (1990).

Dado ao contexto organizacional, instável e competitivo marcado pelos conhecimentos "perecíveis" os autores citados, destacam como as empresas de sucesso que, nos anos 90, identificaram suas core competencies adotaram uma estratégia corporativa disseminada através de suas unidades de negócios.

A esse respeito, Conde (2001, p.35) ressalta que "a clareza na definição da estratégia adotada e o desenho organizacional têm peso decisivo no desempenho da empresa, pois permitem um reconhecimento das competências essenciais aos negócios da empresa".

Definir o posicionamento estratégico e formular uma visão torna-se difícil quando é preciso diferenciar as competências essências das não-essenciais. Segundo Hamel e Prahalad (1990), as “core competencies" passam por três testes:

valor percebido pelo cliente: as competências essenciais da empresa permitem à empresa oferecer aos seus clientes um beneficio real;

$>$ diferenciação dos seus concorrentes: tornar a empresa única, que suas competências essenciais estejam sempre acima da média do mercado; 
capacidade de expansão: as competências essenciais propiciam à empresa a vazão de novos produtos e serviços.

Considerando que a estratégia de negócio orienta todas as ações da empresa em busca dos objetivos traçados, Fleury e Fleury (2000, p.42) ressaltam que "a competência no processo de formulação de estratégias é fundamental".

Ao definir sua estratégia competitiva, a empresa identifica também suas competências essenciais e, conseqüentemente as competências individuais de cada função. A identificação dessas competências possibilita as escolhas estratégicas feitas pela empresa, levando a um circulo vicioso de construção de competências (CONDE, 2001, p. 42).

A gestão de competências implica uma cultura de aprendizagem contínua para que a empresa possa enfrentar mudanças no ambiente e mudanças de estratégia. Segundo Fleury e Fleury (1997, p.19), aprendizagem é "um processo de mudança, resultante da prática ou experiência anterior, que pode vir, ou não, a manifestar-se em uma mudança perceptível de comportamento".

Para tanto, a construção do futuro da empresa baseia-se na competência essencial a fim de que sua estratégia organizacional possa reinventar seu mercado, criando e dominando as oportunidades emergentes.

Compreender e distinguir melhor as competências de uma empresa pode trazer inúmeros benefícios. Quando os gerentes têm opiniões similares sobre as competências mais importantes de sua empresa, tendem a ser mais coerente nas decisões voltadas a desenvolver e fortalecer essas competências, e indicando áreas em é preciso investir para aumentar a condição competitiva da empresa (KING; FOWLER e ZEITHAMI, p. 37, 2002). 


\subsection{COMPETÊNCIA INDIVIDUAL}

Trazendo o conceito de competência para o nível individual, constata-se que as habilidades, potencialidades e atitudes do funcionário são influenciadas pelas competências da organização. Atualmente, segundo Hipólito (2001, p.81), o conceito de competência ampliou-se. Além de considerar o estoque de conhecimentos, habilidades e atitudes de um indivíduo, considera também resultados, produção e entrega decorrentes de sua mobilização, isto é, incorpora o valor adicionado pelo empregado ao negócio (Figura 5).

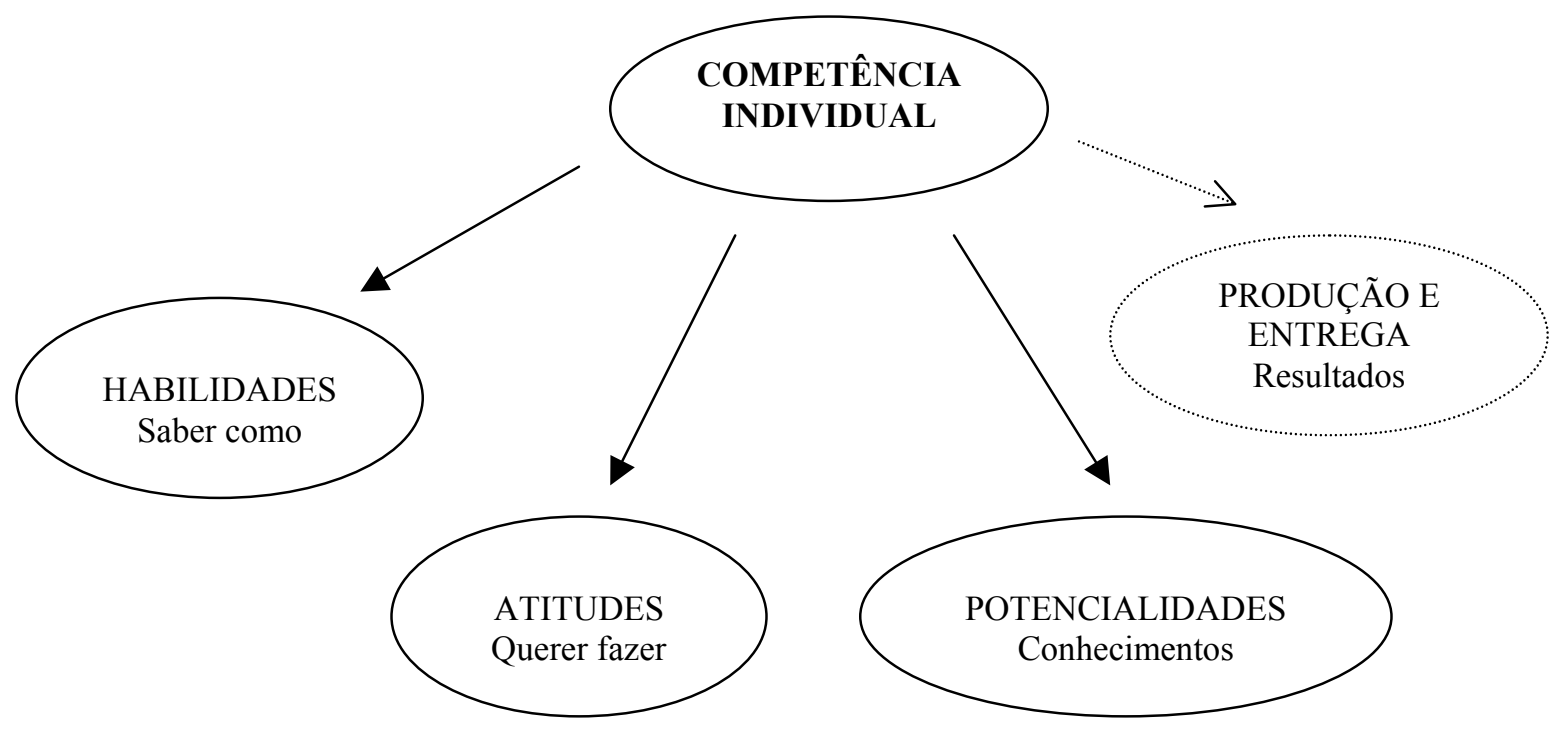

Figura 5 - O conceito de competência individual.

Fonte: Hipólito (2001).

Há basicamente duas linhas de pensamentos sobre o termo "competência": a linha americana sob a denominação "competency" e a linha européia sob a denominação "competence". A principal diferença entre os estudos sobre competência refere-se à forma com que esta é vista: como inputs (conhecimentos) ou outputs (resultados) do comportamento humano. (CONDE, 2001, p.64-66), 
No Reino Unido, as competências são vistas como outputs porque os empregados dispõem competências em graus, conforme o resultado e as metas de seus trabalhos ou o quanto estes superam os padrões de trabalho prescritos. Basicamente, refere-se à entrega da pessoa para a organização (CONDE, 2001, p.66).

Alguns autores discutem com propriedade o conceito de competência, a interação do indivíduo com sua equipe e com seu ambiente de trabalho.

Zarifian (2000) tem uma visão bastante crítica quanto às práticas organizacionais referentes ao assunto. Propõe um outro conceito de competência, mais amplo, incluindo a interação do individuo com o seu ambiente: o assumir responsabilidades, ser reconhecido e recompensado como uma pessoa hábil, como inteligência prática dirigida à situação de trabalho.

Dejours (1997) reforça que a competência humana depende do contexto ético e social, depende tanto do sujeito quanto do outro, ou seja, depende do coletivo. A competência é coletiva antes de ser individual, o que causa impactos significativos no conceito de fator humano. Segundo o autor, o fator humano não pode ser completamente conceituado pela ciência, no mundo cotidiano do trabalho, suas três dimensões irredutíveis são:

$>$ a biológica preocupada com o conhecimento das exigências e dos limites do funcionamento do corpo biológico, nem todos os desempenhos são possíveis;

$>$ a social refere-se ao trabalho supõe uma ação coordenada de pessoas que se compreendem, se opõem, lutam entre si ou concordam, não só sobre a base de princípios técnicos, mas também éticos;

$>$ e a subjetiva que inclui a mobilização subjetiva das personalidades e das inteligências da pessoa nos atos de trabalho.

Para Le Boterf (1995), a competência situa-se na integração de três diferentes planos: o sujeito em si através de sua biografia e sua socialização, a situação profissional 
representada pela organização do trabalho e a situação de formação profissional. O resultado dessa integração é a competência que se revela a partir do trabalho da pessoa e da prática de seus conhecimentos acadêmicos e profissionais.

Portanto, segundo o autor, a competência "é um saber agir responsável e reconhecido, que se traduz em diferentes aspectos como saber mobilizar, saber integrar e saber transferir recursos, conhecimentos e capacidades em um contexto profissional" (Le Boterf, 1995, p.17).

A este respeito, Fleury e Fleury (2000, p.43) explicitam:

"saber agir", significa saber tratar a complexidade e a diversidade, antecipar-se e agir em tempo certo, com visão sistêmica;

> "saber mobilizar", é entender e saber utilizar diferentes formas de recursos (financeiros, humanos e informacionais), buscar parcerias e integrá-las ao negócio;

$>$ "saber comunicar", expressa conhecer a linguagem dos negócios e dos mercados, saber ouvir e comunicar-se eficientemente com stakeholders;

> "saber aprender", é criar uma cultura organizacional, os sistemas e mecanismos requeridos para a aprendizagem;

$>$ "saber assumir responsabilidades", representa saber avaliar as conseqüências das decisões, tanto no plano interno da empresa quanto no nível externo da sociedade;

"ter visão estratégica", significa conhecer e entender profundamente o negócio da organização e seu ambiente, identificando vantagens competitivas e oportunidades.

Sveiby (1998, p.42) conceitua competência de um indivíduo a partir de cinco elementos, conforme apontado na Figura 6:

o conhecimento explícito, envolve conhecimento dos fatos e é adquirido principalmente pela informação, quase sempre pela educação formal;

$>$ a habilidade, a arte de "saber fazer" que envolve uma proficiência prática física e mental, é adquirida pelo treinamento, pela prática e pela comunicação; 
a experiência, adquirida principalmente pela reflexão sobre sucessos e erros passados;

os julgamentos de valor, que são as percepções do que o indivíduo acredita estar certo, são como filtros conscientes e inconscientes para o processo de saber de cada indivíduo;

a rede social, formada pelas relações do indivíduo com outros seres humanos, dentro de um ambiente e uma cultura transmitidos pela tradição.

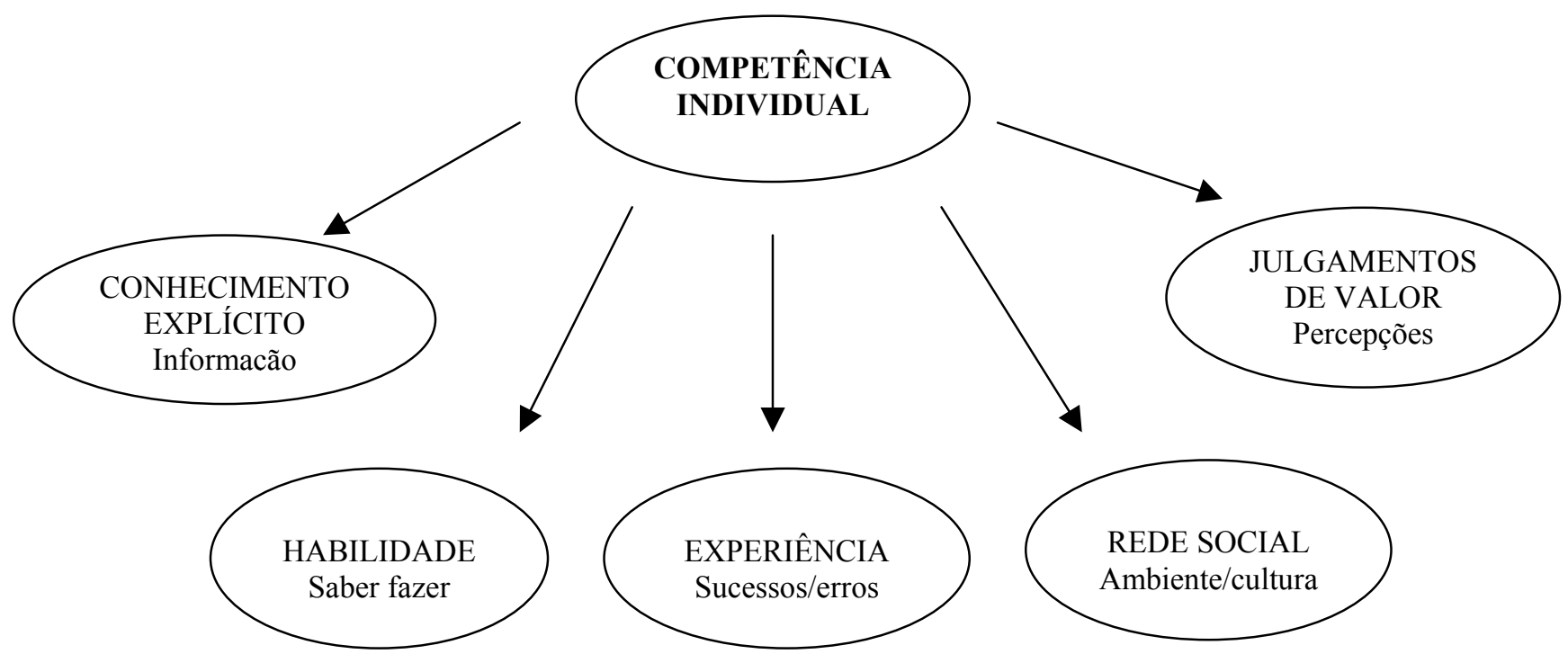

Figura 6 - O conceito de competência individual.

Fonte: Sveiby (1998).

Contrapondo, nos Estados Unidos, as competências são vistas principalmente como inputs, uma vez que consistem em grupos de conhecimentos, atitudes e habilidades que afetam as capacidades de realização dos indivíduos. Sempre, são referidas no plural por representar esse conjunto próprio de cada indivíduo, e que é expresso no seu dia-a-dia, em seu comportamento (CONDE, 2001, p. 66). 
Parry (1996, p.50) define competência como:

um conjunto de conhecimentos, habilidades e atitudes que influenciam a maioria dos trabalhos (papéis ou responsabilidades) de uma pessoa e se correlacionam com o desempenho em um trabalho. Pode ser mensurada quando comparada com padrões aprovados e bem aceitos e pode ser aperfeiçoada através de treinamento e de desenvolvimento.

Segundo Davenport e Prusak (1998, p.6), o conhecimento é:

uma mistura fluida de experiência condensada, valores, informação contextual e insight experimentado, a qual proporciona uma estrutura para avaliação e incorporação de novas experiências e informações. Ele tem origem e é aplicado na mente dos conhecedores. Nas organizações ele costuma estar embutido não só em documentos ou repositórios, mas também em rotinas, processos, práticas e normas organizacionais.

Borrás (2000) descreve "atitude" como sendo a forma de atuação de um indivíduo frente a uma determinada circunstância, e "habilidade" como a capacidade para executar uma determinada tarefa (relacionada com o saber fazer) adquirida através de cursos técnicos, leituras e estudos diversos e, mensurada ou comprovada por meio de provas, certificados, diplomas, etc.

Para o autor, a competência é resultante das experiências vividas, do relacionamento do indivíduo com a sociedade, este condicionado por sua situação profissional, onde o ambiente, em contrapartida, exerce influência em sua formação. Competência é uma constante aprendizagem.

A partir da apresentação de vários autores abordando a questão da competência. O conceito de competência, discutido neste trabalho, envolve diretamente o indivíduo inserido em sua equipe de trabalho através de sua atividade prática, uma vez que sua rotina diária implica num saber aprender e desaprender constante. $\mathrm{O}$ indivíduo deve mostrar-se apto a tomar iniciativa e a assumir responsabilidades diante das situações profissionais com as 
quais se depara. A responsabilidade é, sem dúvida, a contrapartida da autonomia e da descentralização das tomadas de decisão. Não se trata mais de executar ordens, mas de assumir em pessoa a responsabilidade pela avaliação da situação, pela iniciativa exigida e pelos efeitos que vão decorrer dessa situação.

Dessa forma, uma pessoa ou uma equipe ao aceitar assumir suas responsabilidades, aceita ser julgada e avaliada pelos resultados obtidos no campo dos desempenhos pelos quais é responsável. Compromete-se e torna-se explicitamente, devedora dos resultados de sua atividade.

Ser competente é, sem dúvida, agir localmente, tendo a preocupação e a visão dos efeitos globais. É compartilhar conhecimento e mobilizar recursos diante de situações complexas a fim de se atingir metas propostas. Uma unidade de produção deve cumprir, simultaneamente, um conjunto de desempenho relacionados, com redução de custos, qualidade, prazo, capacidade de inovação, e muito mais.

$\mathrm{Na}$ prática, a competência das pessoas manifesta-se na capacidade de julgar e tomar decisões, privilegiando a autonomia frente à observância estrita da disciplina; a responsabilidade frente à obediência cega, e o espírito de equipe e de cooperação frente aos comportamentos egoístas (ZARIFIAN, 2000, p.163).

\subsection{COMPETÊNCIA E DESEMPENHO HUMANO}

Conforme discutido anteriormente, não é possível pensar o conceito de competência sem expor a lógica do desempenho humano, uma vez que a avaliação do desempenho norteia a formação de competências individuais de acordo com as necessidades do negócio.

Lawler III (1995) enfatiza a importância da relação de competências com desempenho individual. Para ele, competências são características demonstráveis de um 
indivíduo, que incluem conhecimentos, habilidades e comportamentos, ligados diretamente com o desempenho.

Com base na gestão estratégica de recursos humanos, o monitoramento do desempenho destaca-se como uma tecnologia importante para a identificação das competências das empresas, tanto organizacionais como individuais.

A utilização de competências nas políticas de uma empresa implica a revisão dos procedimentos de avaliação dos funcionários. Através do monitoramento do desempenho, "cada indivíduo fica ciente de que resultado deve alcançar e como ele pode ser alcançado. As competências embasam a linguagem para definir os comportamentos desejados que permitem a realização do desempenho e melhoramento" (CONDE, 2001, p.80).

Segundo Dutra (2001, p.33), uma das questões mais difíceis na gestão de pessoas é definir e avaliar o desempenho, definido como o conjunto de entregas e de resultados de uma determinada pessoa para a empresa ou negócio.

A avaliação de desempenho possibilita identificar três dimensões do indivíduo que interagem entre si: o desenvolvimento, o esforço e o comportamento (Figura 7). Para o autor:

cada dimensão deve ser tratada de forma diferente, tanto no que se refere à maneira de avaliar quanto no que diz respeito às ações decorrentes da avaliação. Em geral, as empresas misturam essas três dimensões e dão mais ênfase ao esforço e ao comportamento. No momento atual, o desenvolvimento é a dimensão mais importante do desempenho e merece uma atenção diferenciada (DUTRA, 2001, p.35). 


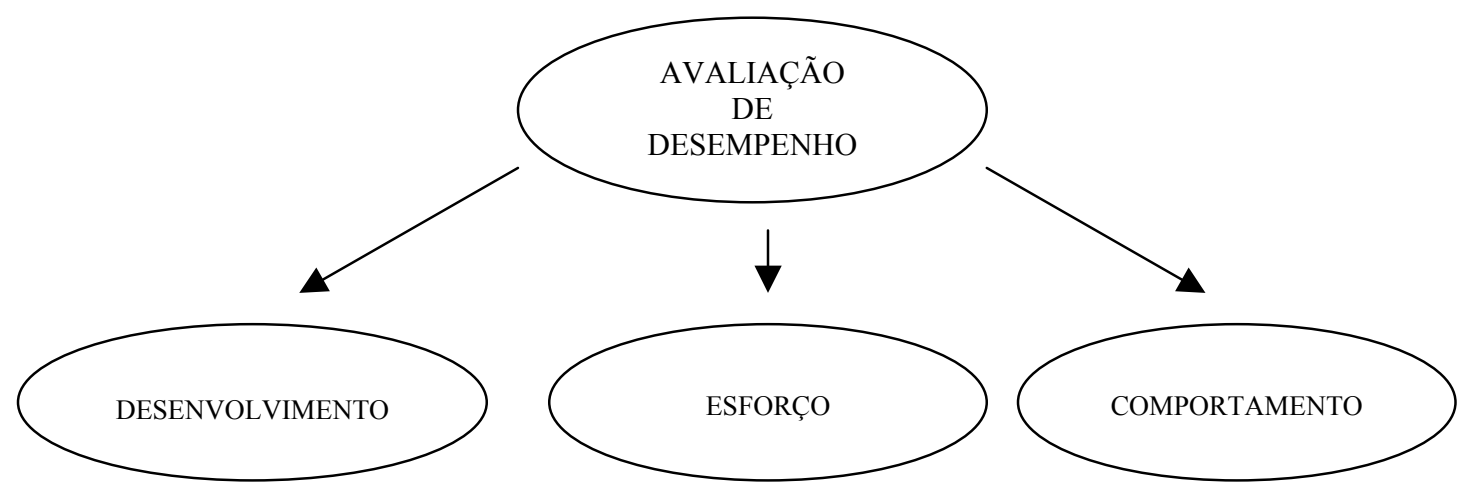

Figura 7 - As três dimensões da avaliação de desempenho.

Fonte: Dutra (2001).

Dejours (1997, p.54) aponta a avaliação de desempenho como um julgamento do trabalho, que pode ocorrer de duas formas: o julgamento de utilidade e o julgamento de beleza. O julgamento de utilidade técnica, social ou econômica da atividade singular do ego (refere-se ao indivíduo) está inserido na esfera do trabalho, e quem o faz, geralmente, ocupa uma posição hierárquica (chefe, supervisor ou organizador) para avaliar a utilidade. $\mathrm{O}$ julgamento de beleza refere-se à conformidade do trabalho e da produção com os padrões estabelecidos, é proferido pelo outro na linha horizontal de paridade e confere ao indivíduo o pertencimento ao coletivo.

Esses julgamentos estão relacionados com o trabalho e suas atividades. O que se avalia e julga é o trabalho e não a pessoa. Na perspectiva de uma teoria do fator humano proposta por Dejours (1997, p.55), esse ponto é essencial porque possibilita o reconhecimento, a compensação pela contribuição do indivíduo por sua contribuição na eficácia do trabalho. 
Devanna, Fombrun e Tichy. (1984), baseando-se nos autores Lorsch e Allen ${ }^{3}$ que conduziram um estudo indicativo de empresas que desenvolvem um sistema de avaliação de desempenho apoiado em sua estratégia de negócio, aponta um link entre o sistema de gestão de recursos humanos e o desenvolvimento global da firma.

O monitoramento do desempenho tem seu primeiro destaque com as avaliações de desempenho propostas pela administração científica, primeiramente sendo feita uma observação direta do trabalhador e do seu processo de trabalho, e depois avaliação dos dados colhidos para então se interferir na realização do trabalho.

A avaliação de desempenho que evolui deste modelo de mão única, no qual somente o chefe analisa seus subordinados a fim de identificar as competências necessárias a cada cargo, para a avaliação de mão dupla, em que chefe e subordinados avaliam-se reciprocamente, discutindo o desempenho do trabalho em termos de metas e resultados. Atualmente, atingindo o estágio, conhecido como avaliação 360 graus, que propõe a utilização de múltiplas fontes inserindo a dimensão de equipe e de contexto organizacional na gestão de desempenho (UBEDA e SANTOS, 2002).

\begin{tabular}{|ll|}
\hline MÃO ÚNICA $\longrightarrow$ & $\begin{array}{l}\text { SUPERIOR AVALIA SEUS } \\
\text { SUBORDINADOS }\end{array}$ \\
MÃO DUPLA $\longrightarrow \begin{array}{l}\text { SUPERIOR E SUBORDINADO SE } \\
\text { AVALIAM RECIPROCAMENTE }\end{array}$ & \\
& AVALIAÇÃO DE MÚLTIPLAS FONTES, \\
AVALIAÇÃO & INSERINDO A DIMENSÃO DE EQUIPE E \\
DE GONAUS CONTEXTO ORGANIZACIONAL NA & GESTÃO DE DESEMPENHO \\
\hline
\end{tabular}

Quadro 3 - A evolução da gestão de desempenho.

Fonte: Ubeda e Santos (2002).

\footnotetext{
${ }^{3}$ LORSCH, J.W. \& ALLEN, A. Managing diversity and interdependence. Boston: Harvard University, 1973 apud in DEVANNA, M.A., FOMBRUN, C.J. \& TICHY, N.M. A framework for strategic human resource management apud FOMBRUN, C.J., TICHY, N.M. \& DEVANNA, M.A., coords. Strategic human resource management. New York: Jonh Wiley, 1984.
} 
Segundo Reis (2000, p.11), a avaliação 360 graus constitui uma técnica na qual os participantes do programa recebem simultaneamente feedbacks estruturados de seus superiores, pares, subordinados e outros stakeholders, sempre com o objetivo de contribuir para o desenvolvimento de comportamentos e habilidades de liderança, demandados pela organização que os utilizam.

A gestão de desempenho, baseada nesta avaliação sistêmica, leva a uma percepção consistente do conjunto de conhecimentos, habilidades e atitudes que precisam ser desenvolvidas na empresa como um todo.

Assim, a gestão de desempenho baseia-se nas competências organizacionais que influenciam diretamente as competências individuais, necessárias à realização das tarefas e dos processos internos e que são percebidos pelas avaliações de desempenho. Conseqüentemente, o feedback dos dados levantados por esta avaliação permite a reciclagem das estratégias e das competências de toda a organização (Figura 8).

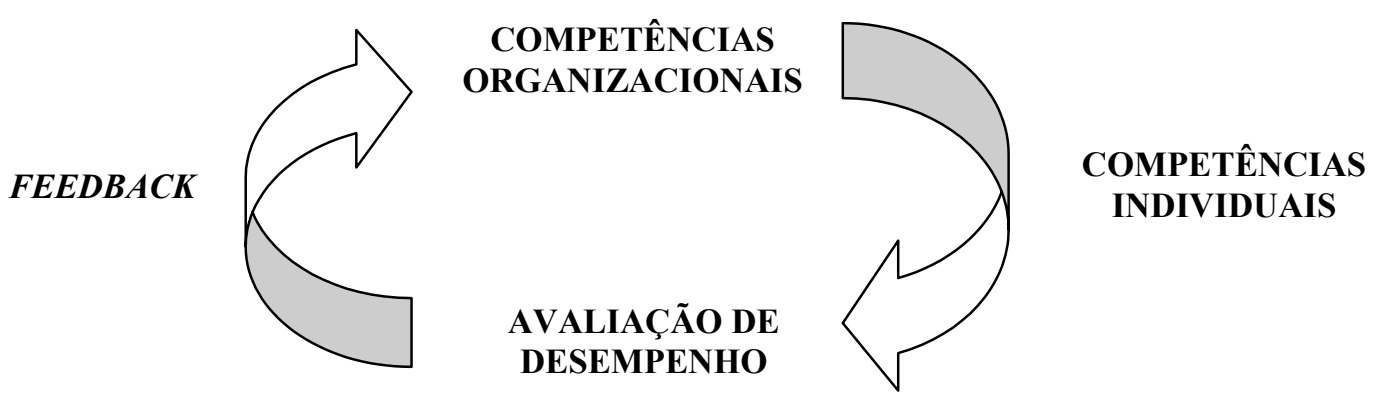

Figura 8 - Abordagem estratégica da gestão de desempenho Fonte: Ubeda e Santos (2002). 
A avaliação de desempenho tradicional apenas compara os resultados alcançados com os esperados, a fim de corrigir os possíveis desvios existentes nos processos que influem na consecução dos resultados.

Como a nova abordagem, a gestão de desempenho integra-se a um processo estratégico maior de gestão de pessoas, porque permite rever estratégias, objetivos, processos de trabalho e políticas de recursos humanos corrigindo os desvios para dar sustentabilidade às competências da organização.

\footnotetext{
Muito mais que uma metodologia de administração e desenvolvimento de recursos humanos, a avaliação de desempenho é um produto de relações sociais específicas, derivadas de estruturas sociais também específicas e, portanto, incorpora não apenas aspectos administrativos (o que, quem, quando, para que e como avaliar) e econômicos, mas também valores culturais, psicológicos e éticos que permeiam as relações de trabalho (GUIMARÃES; LEITÃO e LOURENÇO, 1999, p. 85).
}

Martins (1999, p.64) afirma que o processo de gestão de desempenho é o meio pelo qual a empresa administra seu desempenho de acordo com as estratégias corporativa e funcional. No centro do processo de gestão do desempenho está o sistema de medição de desempenho que integra todas as informações dos sistemas relevantes - revisão e desenvolvimento de estratégia, contabilidade gerencial, administração por objetivos, medidas de desempenho não-financeiras formais e informais, esquemas de incentivos/bônus e avaliações de desempenho individual.

Já a esse respeito, Chiavenato (1996) aponta quatro indicadores de desempenho sistêmicos, visualizando toda a empresa, para a equipe e para a própria pessoa: financeiros, ligados ao cliente, internos, e de inovação. Considera a evolução dos índices de desempenho em confronto com outros indicadores, tanto de origem econômica por mercado, região ou país, quanto de benchmarking, empresas do mesmo ramo.

A medição do desempenho tem se pautado mais pelo entendimento e acordo entre avaliador e avaliado, deixando de lado o julgamento superior e definitivo do 
comportamento do funcionário. Isto é, passa a ser uma negociação sobre os objetivos a serem atingidos, gerente e funcionário trocam idéias e informações, resultando daí um compromisso conjunto por condições necessárias de crescimento profissional e a atingimento de resultados.

\subsection{A GESTÃO DE COMPETÊNCIAS}

A gestão de competências enfoca essencialmente, o desenvolvimento dos recursos humanos, o que as pessoas serão capazes de fazer no futuro, considerando a integração entre estratégia empresarial, sistema de trabalho e cultura organizacional (SANTOS, 1999, p.25).

A gestão de competências, na sua concepção holística, interfere diretamente no bom desempenho futuro de seus recursos humanos (empregados, gerentes e diretores). Ela considera atitudes, valores, características pessoais e relações em equipes e não apenas os conhecimentos e as habilidades para a realização do trabalho.

Dessa forma, a gestão de competências é uma prática estratégica que visa a aumentar o desempenho global da corporação, através do incremento do desempenho individual de seus empregados. Para tanto, os estudos buscam a identificação de fatores que levam os indivíduos a se diferenciarem quanto ao produto de seu trabalho (outputs) ou quanto ao que trazem consigo através de sua formação pessoal (inputs).

O modelo holístico é onde o processo de gerenciamento de desempenho baseado nas competências é fortemente integrado com outros processos chave dentro da organização, p.ex., o processo pode ser estreitamente integrado com o planejamento do negócio - business planning para conseguir um alinhamento entre corporação, time e objetivos pessoais (CONDE, 2001, p.80). 
Por isto, toda a empresa que busca a competitividade e a permanência no mercado tem se importado com a gestão de competências e com o monitoramento do desempenho, como funções estratégicas, uma vez que permitem a inovação através da reciclagem de seus processos, atividades e procedimentos pessoais.

A gestão de competências proporciona um efetivo sistema estratégico de recursos humanos porque sem uma avaliação de desempenho, individual e em grupo, a empresa não consegue acompanhar seu desenvolvimento nem a evolução de desempenho dos seus funcionários, conseqüentemente não consegue criar e gerir suas competências individuais.

A gestão de competências tem se preocupado em cumprir o seguinte ciclo: identificação do que é esperado do empregado, determinação de como o produto/serviço deve ser apresentado, e o feedback do processo. Assim, a gerência pode sistematizar seus processos e atividades, bem como suas políticas e normas internas.

Neste trabalho é proposto um ciclo de formação de competências como um meio de fornecimento de informações para outros sistemas e processos de trabalho da empresa. Antes de qualquer coisa, a empresa deve estabelecer qual a sua missão e quais as suas competências organizacionais e, principalmente, as perspectivas de competências individuais necessárias a cada atividade especifica, para, então, planejar e executar a avaliação de desempenho (Figura 9). 


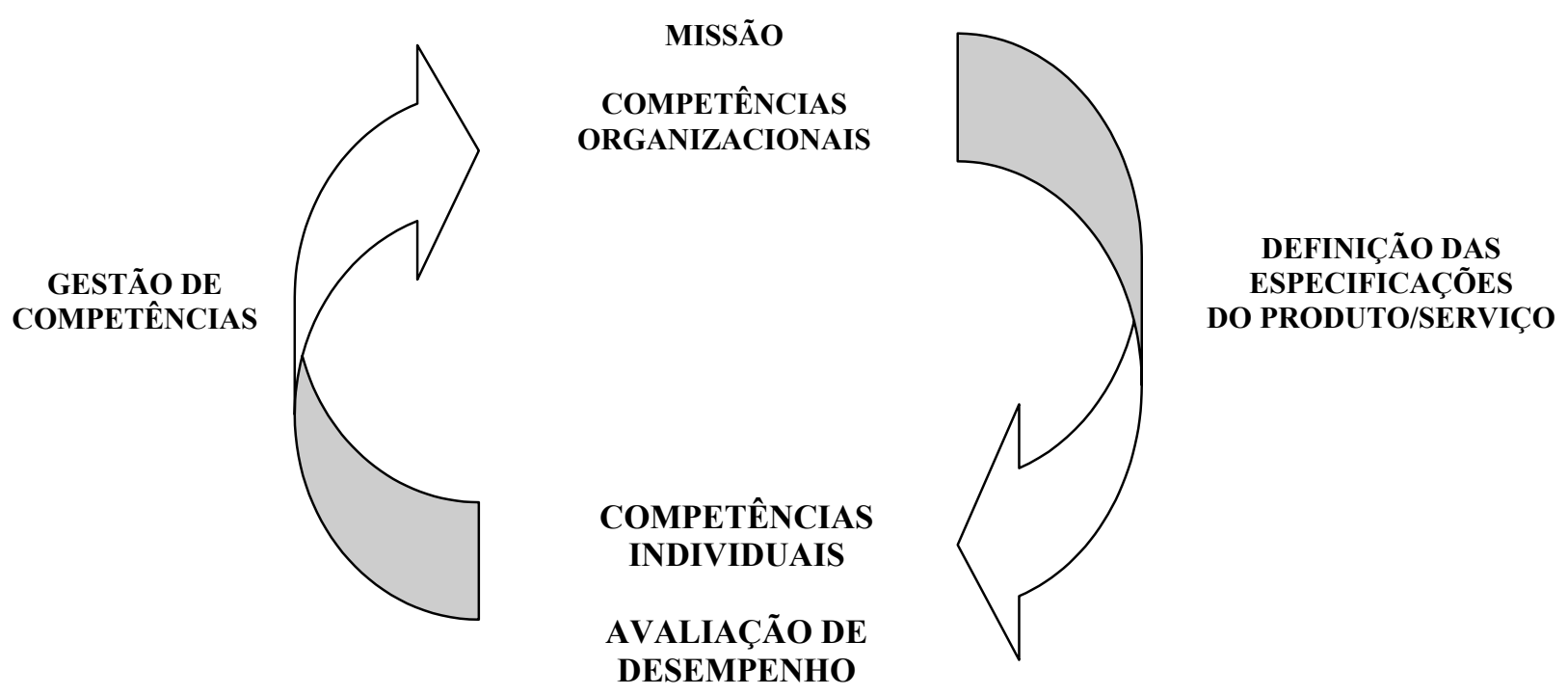

Figura 9 - O ciclo da formação de competências.

Portanto, a gestão de competências tem como principais objetivos:

orientar decisões gerenciais sobre a necessidade de se disponibilizar de recursos e meios para a consecução do trabalho, bem como sobre as necessidades de treinamentos dos empregados;

$>$ planejar as atividades dos empregados e identificar as condições de trabalho que influem no seu desempenho;

nortear as políticas e diretrizes de recursos humanos da empresa;

premiar ou promover e até punir, advertir ou demitir empregados.

Segundo Ramos (2001, p.80-81), um sistema de competência é integrado por três subsistemas: a normalização das competências, a formação das competências e a avaliação e certificação de competências. A investigação das competências tem por objetivo garantir a evidência das competências requisitadas pelos empregos e traçar o perfil profissional. Logo, é possível elaborar as normas de competências mediante a confrontação do perfil com as ocupações ou situações típicas de trabalho, deduzindo-se os desempenhos satisfatórios. A formação de competências pode acontecer por processos de aquisição de 
competências promovidos pelo próprio Estado ou pelas empresas interessadas. As competências validadas tornam-se instrumentos de negociação do trabalhador a fim de gerar mobilidade profissional, ganhos de remuneração, acesso à educação continuada e desenvolvimento profissional.

Assim, a gestão de competência pode ser uma ferramenta útil às estratégias de produção, no sentido de possibilitar à organização tornar-se competitiva e posicionar-se frente à concorrência. A organização deve buscar aliar suas competências com a sua estratégia, seja ela voltada para a qualidade, a inovação, a flexibilidade, ou a pontualidade. $\mathrm{O}$ fator determinante é a necessidade do cliente final envolvido no processo.

As empresas integram a gestão de competências com o planejamento estratégico, podendo fazer uso do balanced scorecard para medir o desempenho organizacional sob quatro perspectivas equilibradas: financeira, do cliente, dos processos internos da empresa, e do aprendizado e crescimento (Figura 10).

Segundo Kaplan e Norton (1997, p.264):

deve-se então criar um sistema de feedback estratégico para testar, validar e modificar as hipóteses incorporadas à estratégia da unidade de negócios. As relações de causa e efeito incorporadas ao balanced scorecard permitem que os executivos estabeleçam metas de curto prazo refletindo suas melhores estimativas sobre deficiências e impactos entre mudanças nos vetores de desempenho e mudanças correlatas em uma ou mais medidas de resultado. 


\section{FINANCEIRA}

Para ser bem-sucedidos financeiramente, qual deve ser a avaliação dos acionistas?

\section{CLIENTES}

Para alcançar a visão estabelecida, qual deve ser a avaliação dos clientes?

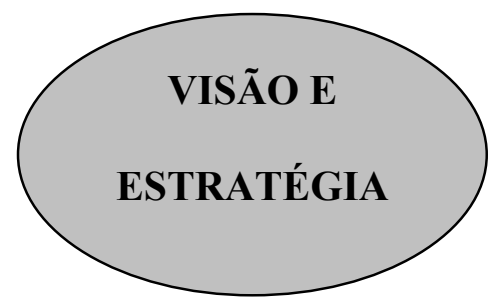

\section{PROCESSOS INTERNOS}

Para satisfazer os acionistas e clientes, em que processos de negócios deve-se alcançar a excelência?

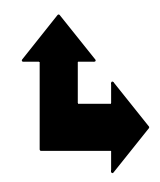

APRENDIZAGEM

E CRESCIMENTO

Para alcançar visão estabelecida, como sustentar a capacidade de mudar e melhorar?

Figura 10 - Estrutura necessária para a tradução da estratégia em termos operacionais.

Fonte: Kaplan e Norton (1997).

Nesse sentido, a qualidade da decisão limita-se às informações disponíveis em termos de qualidade e quantidade. $\mathrm{O}$ benefício mais importante de medidas de desempenho adequadas é o entendimento de como o sistema de produção funciona e quais são as forças que o dirigem. Isso enriquece o processo de tomada de decisão (MARTINS, 1999, p.64). 


\subsection{GESTÃO DE COMPETÊNCIAS E SUBSISTEMAS DE RECURSOS HUMANOS}

Quando a gestão de competências está integrada com a estratégia da empresa, é possível verificar a relação entre a identificação de competências pessoais e os principais subsistemas de recursos humanos: recrutamento e seleção, treinamento e desenvolvimento, recompensas e remuneração, e gestão de carreira.

Através do feedback dos resultados e dos dados da avaliação de desempenho, os supervisores e os empregados podem identificar quais as habilidades e conhecimentos necessários às atividades desenvolvidas, e quais os requisitos de treinamento para a melhoria dos processos do gerenciamento de projetos.

Fischer (1998, p.356) destaca alguns princípios orientadores das políticas e processos de gestão de recursos humanos presentes em seus estudos de casos e na literatura contemporânea:

empregabilidade pautada pelo mercado de trabalho;

$>$ autodesenvolvimento pela agregação de competências;

$>$ foco nos resultados obtidos pelas pessoas como incremento para o negócio da empresa;

empowerment como autonomia ou maior poder de decisão das chefias na gestão de suas equipes de trabalho.

De acordo com esses princípios, a organização pode orientar suas práticas e objetivos de recrutamento. Sveiby (2000, p.78) observa que o recrutamento é a prática mais importante da gerência e talvez, a sua ferramenta mais importante, porque através do recrutamento estratégico, a empresa pode modificar suas estratégias e pode aumentar ou reduzir sua competência e outros ativos intangíveis. 
O recrutamento direcionado para a estratégia da empresa e as políticas de desenvolvimento pessoal, demonstra a postura da empresa de privilegiar, reter e desenvolver conhecimento.

O desenvolvimento pessoal num contexto organizacional requer esforços combinados do indivíduo (aspirações e motivações) e da organização gerando oportunidades e estímulos ao desenvolvimento das competências necessárias para o sucesso da organização (DUTRA, 1996, p.64).

Cabe à empresa estimular seus funcionários a investirem em seu autodesenvolvimento, gerando condições propícias para a produção do conhecimento no ambiente de trabalho (DUTRA, 1996, p.64).

Segundo Zarifian (2001, p. 121), não se obriga um indivíduo a ser competente. A empresa pode somente criar condições favoráveis a seu desenvolvimento e validá-las. Nesse sentido, a motivação torna-se elemento chave para o desenvolvimento de competências. É preciso que o funcionário sinta-se útil e aceite assumir responsabilidades. O indivíduo ficará mais motivado à medida que pensar que a mobilização de suas competências concorre também para o desenvolvimento de seus projetos e perspectivas.

Para tanto, é necessário ao indivíduo maturidade para conscientização e compreensão do real sentido da aprendizagem e do desenvolvimento contínuo, para que se instalem as competências humanas mais importantes para o sucesso da empresa onde trabalha (EBOLI, 2001, p.113).

Já da área de recursos humanos é requerida uma atuação estratégica, por intermédio de uma gestão por competências que permita o alinhamento de atuação entre competências humanas e empresariais (EBOLI, 2001, p.113). 
Ao se avaliar um desempenho compatível com o esperado, é de se esperar uma recompensa por tal fato. Estas recompensas podem ser pautadas pelos resultados e metas atingidas, pelo conhecimento adquirido ou pelo comportamento relacionado com a cultura organizacional.

Ao tratar do desempenho, Hipólito (2001, p.75) destaca:

a prática remuneratória deve ser estruturada, portanto, de tal forma, que reforce valores, crenças e comportamentos alinhados com as atuais demandas da organização e com seu direcionamento estratégico; que estimule a busca de aquisição e estruturação de conhecimento, bem como seu compartilhamento no contexto empresarial; que sirva de elemento interveniente na capacidade da organização de atrair e reter talentos; e, ao demonstrar coerência, que sustente o comprometimento e estimule ações que estejam de acordo com os objetivos da organização.

Além dessa prática remuneratória clara e estruturada, a organização deve também se preocupar com as recompensas intangíveis, como reconhecimento dos colegas, oportunidades de aprendizado, maior autonomia e independência.

O elo entre a empresa e as pessoas-chave talvez nunca venha a ser eliminado por completo nas empresas do conhecimento, porque o próprio trabalho é um processo criativo no qual os indivíduos estão profundamente envolvidos. Assim, uma estratégia da área de pessoal que englobe recrutamento, gerenciamento e desenvolvimento de pessoal pode ajudar na realização desse objetivo (SVEIBY, 1998, p.78). 


\subsection{CONSIDERAÇÕES FINAIS}

A busca das organizações por novas capacidades estratégicas em Engenharia de Produção, para assegurar seu sucesso competitivo, ressalta ainda mais a importância da gestão de competências das suas subáreas, por meio da identificação de competências individuais e do monitoramento do desempenho para a construção da estratégia empresarial.

Diante desse contexto, o presente estudo foca a análise da gestão de competências e da avaliação de desempenho em uma empresa de pesquisa e desenvolvimento. 


\section{ESTUDO DE CASO}

O objetivo deste capítulo é apresentar o estudo de caso realizado na Embrapa Pecuária Sudeste, bem como descrever suas práticas de avaliação de desempenho, gestão de competências e seus subsistemas de recursos humanos.

\subsection{METODOLOGIA DE PESQUISA}

Tendo em vista o propósito deste estudo, optou-se por realizar pesquisa descritiva, a partir de uma abordagem qualitativa e exploratória, utilizando o estudo de caso para confrontar a teoria com a prática.

Becker (1994), pontua que o estudo de caso possibilita observar, descrever e explorar aspectos de uma realidade, o que vem ao encontro da expectativa desta investigação, que é o de ampliar a compreensão acerca dos aspectos concernentes a uma organização.

Pretende-se descrever como a gestão de competências, identificando-se as competências individuais, contribui para a melhoria dos processos e das estratégias de recursos humanos e de inovação, e ainda, identificar o impacto desse gerenciamento nas práticas de pesquisa e de desenvolvimento.

O estudo de caso foi realizado na Embrapa Sudeste, localizada na cidade de São Carlos, interior do estado de São Paulo, com a finalidade de identificar as estratégias de inovação e a gestão de competências da Instituição Embrapa.

A Embrapa foi escolhida para o estudo de caso porque atende as expectativas da pesquisa: ser estrategicamente voltada para a pesquisa e desenvolvimento, ter um 
instrumento de avaliação de desempenho estruturado e implantado e, integrar seus processos com a gestão de recursos humanos.

Dentro desta perspectiva, procedeu-se um estudo empírico utilizando como métodos para coleta de dados, a entrevista (Anexo A), a observação participante e a análise documental.

A entrevista possibilitou o entendimento de como os sujeitos da pesquisa percebem “questões relacionadas à identificação e gestão de competências". Foram entrevistados os profissionais que participam da gestão de competências e do gerenciamento de recursos humanos da empresa estudada. Entre eles: 4 funcionários do Setor de Recursos Humanos, o Chefe Adjunto da Pesquisa do Centro e 2 pesquisadores.

A observação participante e a análise de documentos proporcionaram um contato pessoal e estreito do pesquisador com a organização, identificando materiais institucionais, normas, rotinas e programas desenvolvidos aos profissionais.

As questões norteadoras deste estudo de caso na Embrapa versaram sobre:

importantes modelos de competências instituídos;

$>$ principais problemas que enfrenta e que precisa resolver; principais projetos de inovação que planeja e executa;

> maneira de desenvolvimento das competências necessárias relativas aos principais problemas e projetos de inovação;

$>$ modo de mensuração dos resultados do desenvolvimento de competências;

$>$ aspectos da estrutura da Embrapa que favorecem ou dificultam a gestão de competências.

A análise documental baseou-se no estudo dos materiais institucionais, nos editais e portarias da Instituição. 
A fundamentação teórica, os dados obtidos e o questionamento pessoal do pesquisador foram os pontos de apoio para se relacionarem os objetivos da pesquisa e a realidade vivenciada na empresa.

\subsection{DESENVOLVIMENTO DA PESQUISA}

Esta pesquisa é resultado do estágio de 20 horas semanais, realizado no Setor de Recursos Humanos (SRH) na Embrapa Pecuária Sudeste, centro de pesquisa localizado na cidade de São Carlos, no período de setembro a outubro do ano de 2003.

O estudo de caso tem pretensão de descrever a gestão de competências numa empresa de pesquisa e desenvolvimento, apresentando a avaliação de desempenho como uma ferramenta importante na identificação de competências humanas focadas na estratégia traçada pela a Empresa.

Conseqüentemente, faz-se também a análise da correlação do ciclo estratégico de desempenho com os subsistemas de recursos humanos: recrutamento e seleção, treinamento e desenvolvimento e remuneração.

\subsubsection{A EMPRESA BRASILEIRA DE PESQUISA AGROPECUÁRIA}

A Empresa Brasileira de Pesquisa Agropecuária, Embrapa, é uma empresa pública vinculada ao Ministério da Agricultura, Pecuária e Abastecimento, criada em 26 de abril de 1973. Sua missão é viabilizar soluções para o desenvolvimento sustentável do agronegócio brasileiro por meio de geração, adaptação e transferência de conhecimentos e tecnologias, 
em benefício da sociedade (EMPRESA BRASILEIRA DE PESQUISA AGROPECUÁRIA, 2003).

A Embrapa atua por intermédio de 37 centros de pesquisa, 3 centros de serviços nacionais e 11 unidades centrais, estando presente em quase todos os Estados da Federação, nas mais diferentes condições ecológicas. Segundo informações disponíveis no site institucional da Embrapa, a Empresa vem investindo em treinamento de recursos humanos desde sua criação, possuindo, em 2003, 8.619 empregados, dos quais 2.221 são pesquisadores, $45 \%$ com mestrado e $53 \%$ com doutorado.

A Embrapa é uma instituição que se preocupa basicamente com pesquisa e desenvolvimento de novas tecnologias, que possam facilitar a vida dos produtores e dos trabalhadores agrícolas no País.

Está sob a sua coordenação o Sistema Nacional de Pesquisa Agropecuária (SNPA), constituído por instituições públicas federais e estaduais, universidades, empresas privadas e fundações, que, de forma cooperativa, executam pesquisas nas diferentes áreas geográficas e campos do conhecimento científico (EMBRAPA, 2003).

Tecnologias geradas pelo SNPA aprimoraram a agricultura brasileira. Um conjunto de tecnologias para programas específicos de desenvolvimento de produtos agrícolas, reflete o expressivo aumento na produção de hortaliças, de grãos, de frangos e de carne bovina no Brasil. Além disso, esses programas conseguiram organizar sistemas de produção para aumentar a eficiência da agricultura familiar e incorporar pequenos produtores no agronegócio, garantindo melhoria na sua renda e no seu bem-estar. 
Na área de cooperação internacional, a Empresa mantém 275 acordos de cooperação técnica com 56 países e 155 instituições de pesquisa internacionais, envolvendo principalmente a pesquisa em parceria. Para ajudar neste esforço, a Embrapa instalou nos Estados Unidos e na França, com apoio do Banco Mundial, laboratórios virtuais de prospecção tecnológica e de articulação institucional instalados nos Estados Unidos e na França. São os chamados Labex - USA e Labex - França. Esses laboratórios contam com a mais alta tecnologia em recursos naturais, biotecnologia, informática e agricultura de precisão.

Em 1991, a Embrapa iniciou um processo de mudança organizacional, com o uso de técnicas de planejamento estratégico,direcionando seu foco para o mercado, orientando suas pesquisas para a solução de problemas sócio-técnicos e não ao avanço strictu sensu da ciência e buscando o aumento da eficiência e da eficácia, para se manter competitiva e garantir sua sustentabilidade (NADER, GUIMARÃES e RAMAGEM, 1998).

Para atender a esse plano estratégico, a Embrapa conta com as unidades centrais que são, ao lado da Diretoria Executiva, órgãos integrantes da administração superior da Empresa. Compete a essas unidades planejar, supervisionar, coordenar e controlar as atividades relacionadas à execução de pesquisa agropecuária e à formulação de políticas agrícolas.

Entre os objetivos globais da Embrapa estão a viabilização de soluções tecnológicas voltadas para:

$>$ o desenvolvimento de um agronegócio competitivo em uma economia global;

o agronegócio que promova a sustentabilidade das atividades econômicas com equilíbrio ambiental;

a diminuição dos desequilíbrios ambientais; 
o fornecimento de matérias-primas e alimentos que promovam a saúde e a melhoria do nível nutricional e da qualidade de vida da população.

Além das unidades centrais, a Embrapa possui uma rede de 40 unidades descentralizadas e distribuídas nas diversas regiões do Brasil, classificadas de serviços, pesquisa e de produtos, pesquisa de temas básicos e pesquisa agroflorestal.

As Unidades de serviço são:

Embrapa Café, em Brasília - DF;

Embrapa Informação Tecnológica, em Brasília - DF;

Embrapa Transferência de Tecnologia, em Brasília - DF.

As Unidades de pesquisa de produtos são:

Embrapa Mandioca e Fruticultura, em Cruz da Almas - BA;

Embrapa Milho e Sorgo - Sete Lagoas - MG;

Embrapa Algodão, em Campina Grande - PB;

Embrapa Arroz e Feijão, em Santo Antonio de Goiás - GO;

Embrapa Caprinos, em Sobral - CE;

Embrapa Florestas, em Colombo - PR;

Embrapa Gado de Corte, em Campo Grande - MS

$>$ Embrapa Gado de Leite, em Juiz de Fora - MG;

$>$ Embrapa Hortaliças, em Brasília - DF;

> Embrapa Pecuária Sudeste, em São Carlos - SP;

$>$ Embrapa Pecuária Sul, em Bagé - RS; 
Embrapa Soja, em Londrina - PR;

Embrapa Suínos e Aves, em Concórdia - SC;

$>$ Embrapa Trigo, em Passo Fundo - RS;

> Embrapa Uva e Vinho, em Bento Gonçalves - RS.

As Unidades de pesquisa de temas básicos são:

Embrapa Agrobiologia, em Seropédica - RJ;

Embrapa Agroindústria de Alimentos, no Rio de Janeiro - RJ;

Embrapa Agroindústria Tropical, em Fortaleza - CE;

Embrapa Informática Agropecuária, em Campinas - SP;

> Embrapa Instrumentação Agropecuária, em São Carlos - SP;

$>$ Embrapa Meio Ambiente - Jaguariúna - SP;

Embrapa Monitoramento por satélite, em Campinas - SP;

Embrapa Recursos Genéticos e Biotecnologia, em Brasília - DF;

Embrapa Solos, no Rio de Janeiro - RJ;

As Unidades de pesquisa agroflorestal ou agropecuária nas ecorregiões brasileiras:

$>$ Embrapa Acre, em Rio Branco - AC;

> Embrapa Agropecuária Oeste, em Dourados - MS;

Embrapa Meio Norte, em Teresina - PI;

Embrapa Amapá, em Macapá - AP;

Embrapa Amazônia Ocidental, em Manaus - AM;

Embrapa Amazônia Oriental, em Belém - PA; 
Embrapa Cerrados, em Planaltina - DF;

Embrapa Clima Temperado, em Pelotas - RS;

D Embrapa Pantanal, em Corumbá - MS;

> Embrapa Rondônia, em Porto Velho - RO;

Embrapa Roraima, em Boa Vista - RR;

Embrapa Semi-Árido, em Petrolina - PE;

Embrapa Tabuleiros Costeiros, em Aracaju - SE;

\subsubsection{A EMBRAPA PECUÁRIA SUDESTE}

Esta unidade da Embrapa foi criada em 26 de agosto de 1975, pela incorporação da Estação Experimental de São Carlos, fazenda Canchim. Em $1^{\circ}$ de maio de 1995, transformada em centro de pesquisa, passou a denominar-se Centro de Pesquisa de Pecuária do Sudeste, e atualmente, Embrapa Pecuária Sudeste.

A Fazenda Canchim passou para a União como pagamento de dívida fiscal, e em 1935 foi encampada pelo Ministério da Agricultura, substituindo a antiga Estação Experimental de criação de gado. A principal realização da Estação Experimental, trabalho do Veterinário e Zootecnista Antonio Teixeira Vianna, foi a formação da raça de corte denominada Canchim, o mesmo nome da fazenda, além da criação do gado Charolês, do cavalo Árabe e de suínos, projetando o nome Canchim no cenário nacional e internacional.

Com a incorporação da propriedade pela Embrapa, os programas de pesquisa foram reestruturados e direcionados para os segmentos de gado de corte, gado de leite, eqǘdeos e 
forragicultura. Para cada segmento, foram estabelecidos projetos de pesquisa, visando atender as necessidades da pecuária regional e nacional.

Atualmente, a Embrapa Pecuária Sudeste possui um plantel constituído de, aproximadamente, 2500 animais, utilizados em pesquisas e nos modelos de sistemas de produção. Contando com vários laboratórios e atividade de apoio.

De acordo com o II Plano Diretor da Unidade (2000-2003), a Embrapa Pecuária Sudeste tem como missão viabilizar soluções tecnológicas competitivas para o desenvolvimento sustentável do agronegócio da bovinocultura de corte e de leite da região Sudeste do País, em benefício da sociedade.

A visão da Unidade é ser um Centro de Pesquisa e Desenvolvimento de referência no agronegócio da bovinocultura da região Sudeste no Brasil, reconhecido pelas seguintes características:

$>$ excelência de sua contribuição técnico-científica;

$>$ capacidade de viabilizar parcerias com outras instituições de ensino, de pesquisa e de desenvolvimento, empresas do agronegócio da bovinocultura e organizações representativas da sua clientela;

capacidade de viabilizar novos modelos de produção com base tecnológica;

$>$ capacidade de oferecer soluções adequadas para a sua clientela;

$>$ respeito, conservação e melhoria do ambiente;

estrutura leve, ágil e concentrada na atividade-fim. 
A estrutura da Embrapa Pecuária Sudeste está sob a coordenação de uma Chefia Geral e organizada em três Chefias Adjuntas: Pesquisa e Desenvolvimento, Comunicação e Apoio e, Administração. Tal estrutura pode ser visualizada pelo organograma seguinte (Figura 11).

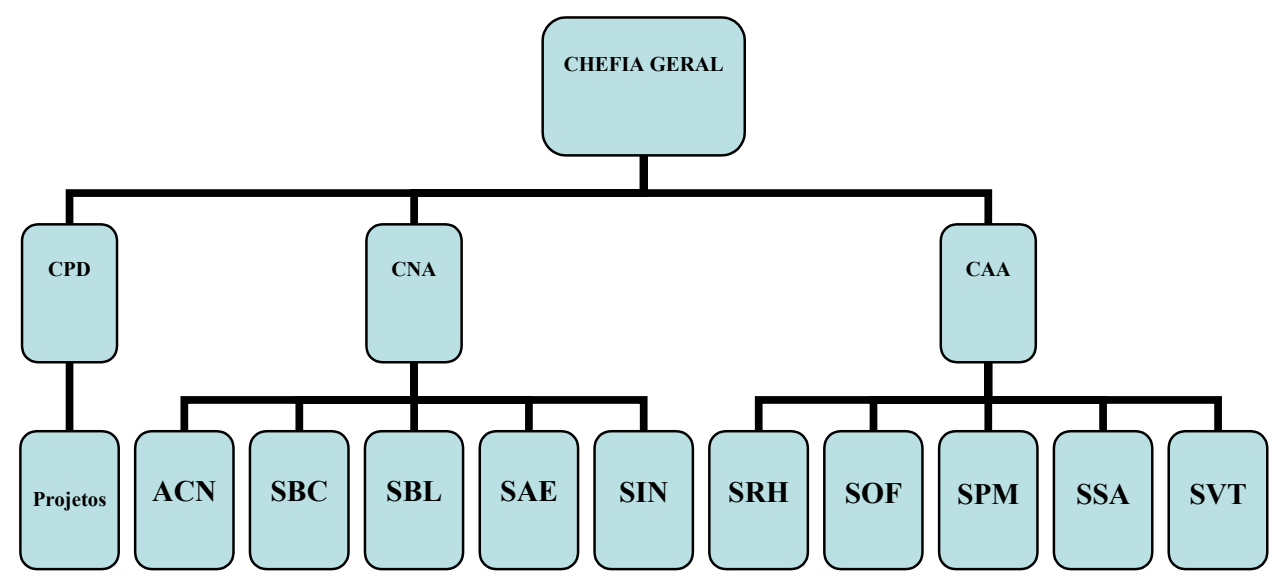

Figura 11 - Organograma do Centro de Pesquisa Embrapa Pecuária Sudeste

Legenda:

CPD - Chefia Adjunta de Pesquisa e Desenvolvimento

CNA - Chefia Adjunta de Comunicação, Negócios e Apoio

ACN - Área de Comunicação e Negócios

SBC - Setor de Bovinocultura de Corte

SBL - Setor de Bovinocultura de Leite

SAE - Setor de Apoio EStratégico

SIN - Setor de Informação

CAA - Chefia Adjunta de Administração

SRH - Setor de Recursos Humanos

SOF - Setor de Orçamento, Contabilidade e Finanças

SPM - Setor de Patrimônio e Material

SSA - Setor de Serviços Auxiliares

SVT - Setor de Veículos e Transporte 
Há seis grandes linhas temáticas de pesquisa na Embrapa Pecuária Sudeste: forragicultura, biotecnologia e sanidade, produção animal - gado de corte, produção animal - gado de leite, química analítica e agricultura familiar. Os pesquisadores da Unidade podem atuar em mais de uma linha de um campo temático ao mesmo tempo.

A coordenação dessas linhas temáticas de pesquisa e dos projetos desenvolvidos na Unidade cabe ao Comitê Técnico Interno, o CTI. Além de outras atividades, cabem a esse Comitê analisar técnica, operacional e orçamentariamente as pré-propostas e propostas de projetos e processos de sua Unidade (EMBRAPA, Resolução Normativa ${ }^{\circ}{ }^{\circ} 17 / 2000$ c).

Dessa forma, cada novo projeto é submetido a avaliação e a aprovação do CTI. Uma vez aprovado, o projeto passa a ser desenvolvido, e quando concluído é avaliado novamente pelo CTI para apreciação de seus resultados, assegurando o compromisso de seu pessoal e a qualidade técnica e dos projetos e processos internos.

\subsubsection{MUDANÇAS ORGANIZACIONAIS OCORRIDAS NA EMBRAPA}

Conforme relatado, anteriormente, a instituição Embrapa foi criada na década de 70, período marcado pelo milagre econômico e pela formação da elite do conhecimento no aparelho público. Simultaneamente nesse período, houve a maior preocupação com a formação de seus recursos humanos e de uma massa crítica voltada para a pesquisa e desenvolvimento, no caso, agropecuário.

Nessa época, a Embrapa não sofria de problemas de recursos financeiros nem humanos, porque o foco do Governo Federal era formar uma instituição de vanguarda no 
assunto. As linhas de pesquisas eram definidas pela Embrapa Sede para serem desenvolvidas nas Unidades de Execução de Pesquisa de Âmbito Estadual, as UEPAEs.

As UEPAEs eram localizadas regionalmente por produto e foram criadas para resolver problemas locais. Estas recebiam e executavam as diretrizes traçadas pela Embrapa Sede para executar políticas de âmbito nacional, e não havia nenhuma preocupação com a avaliação de resultados.

A partir de 1988, com a aprovação da atual Constituição Federal, as instituições públicas passaram a se preocupar mais com a gestão estratégica de processos e com a avaliação de resultados, tanto organizacionais quanto individuais.

Buscando, então, acompanhar essas mudanças de paradigmas organizacionais e tecnológicos, a Embrapa passou a internalizar em sua cultura institucional os princípios de planejamento estratégico e elaborou seu primeiro Plano Diretor, para o período de 19881992.

O segundo Plano Diretor - 1994-1998 contou com uma análise do cenário nacional e internacional, possibilitando identificar ameaças e oportunidades, redefinir a missão e os objetivos da empresa e estabelecer diretrizes estratégicas e um sistema de planejamento.

O terceiro e atual Plano Diretor da Embrapa surge para atender à necessidade de orientar as estratégias da Empresa no período de 1999-2003. Propõe o realinhamento estratégico, focando suas ações para vencer novos desafios do cenário global.

O III Plano Diretor postula entre outras diretrizes estratégicas: o foco no cliente e a estrutura por processo. Processos esses que utilizam os recursos da organização para oferecerem resultados objetivos aos seus clientes (SENTANIN, 2003). 
O Quadro 4 faz um resumo histórico dos cenários organizacionais da Embrapa.

\begin{tabular}{|c|c|}
\hline PERÍODO & CENÁRIOS ORGANIZACIONAIS DA EMBRAPA \\
\hline Década de 70 & $\begin{array}{l}\text { - formação e consolidação da Empresa; } \\
\text { - criação e desenvolvimento de seus recursos humanos; } \\
\text { - disponibilidade de recursos financeiros para o desenvolvimento de } \\
\text { projetos. }\end{array}$ \\
\hline 1988 a 1992 & $\begin{array}{l}\text { - } \quad \text { modernização da gestão empresarial; } \\
\text { - } \quad \text { aplicação do planejamento estratégico; } \\
\text { - foco no resultado. }\end{array}$ \\
\hline 1994 a 1998 & $\begin{array}{l}\text { - } \quad \text { análise de cenários globais; } \\
\text { - } \quad \text { redefinição da missão e visão da Empresa; } \\
\text { - definição de uma política global da Empresa composta por: pesquisa e } \\
\text { desenvolvimento, negócios e comunicação empresarial. }\end{array}$ \\
\hline 1999 a 2003 & $\begin{array}{l}\text { - foco no cliente; } \\
\text { - estrutura por processos/projetos. }\end{array}$ \\
\hline
\end{tabular}

Quadro 4 - Cenários Organizacionais da Embrapa

Para implementar as propostas do III Plano Diretor a Empresa iniciou um processo de reestruturação. As Unidades foram incentivadas a adotar a estrutura por processos em substituição a estrutura funcional predominante na Empresa. Nesse novo modelo foram definidas, na estrutura da Unidade, apenas a chefia geral e chefias adjuntas e as áreas de comunicação e negócios. No nível das supervisões foram definidos os processos de trabalho, em substituição aos setores e às áreas tradicionais (SENTANIN, 2003). 
Para se manter competitiva e garantir sua sustentabilidade, a Embrapa adotou um processo de mudança organizacional baseado no modelo de gestão de resultados e nas exigências de seus clientes, apoiado na metodologia do Balanced Scorecard (BSC).

Assim, no período de 1997 - 1999, a Empresa propôs um projeto piloto de um novo Modelo de Gestão Estratégica -MGE para suprir a necessidade da existência de indicadores que traduzissem o que determinava o Plano Diretor: todos os empregados da Empresa trabalhando em prol das metas traçadas (SENTANIN, 2003).

O MGE permite aos gerentes verificar se as atividades e os projetos realizados levam a Empresa na direção desejada, por meio de mecanismo de monitoramento das ações e das decisões. Seu objetivo é buscar a excelência da gestão, formulando mecanismos de execução das estratégias da empresa que permitam melhor alocação dos recursos disponíveis (Figura 12).

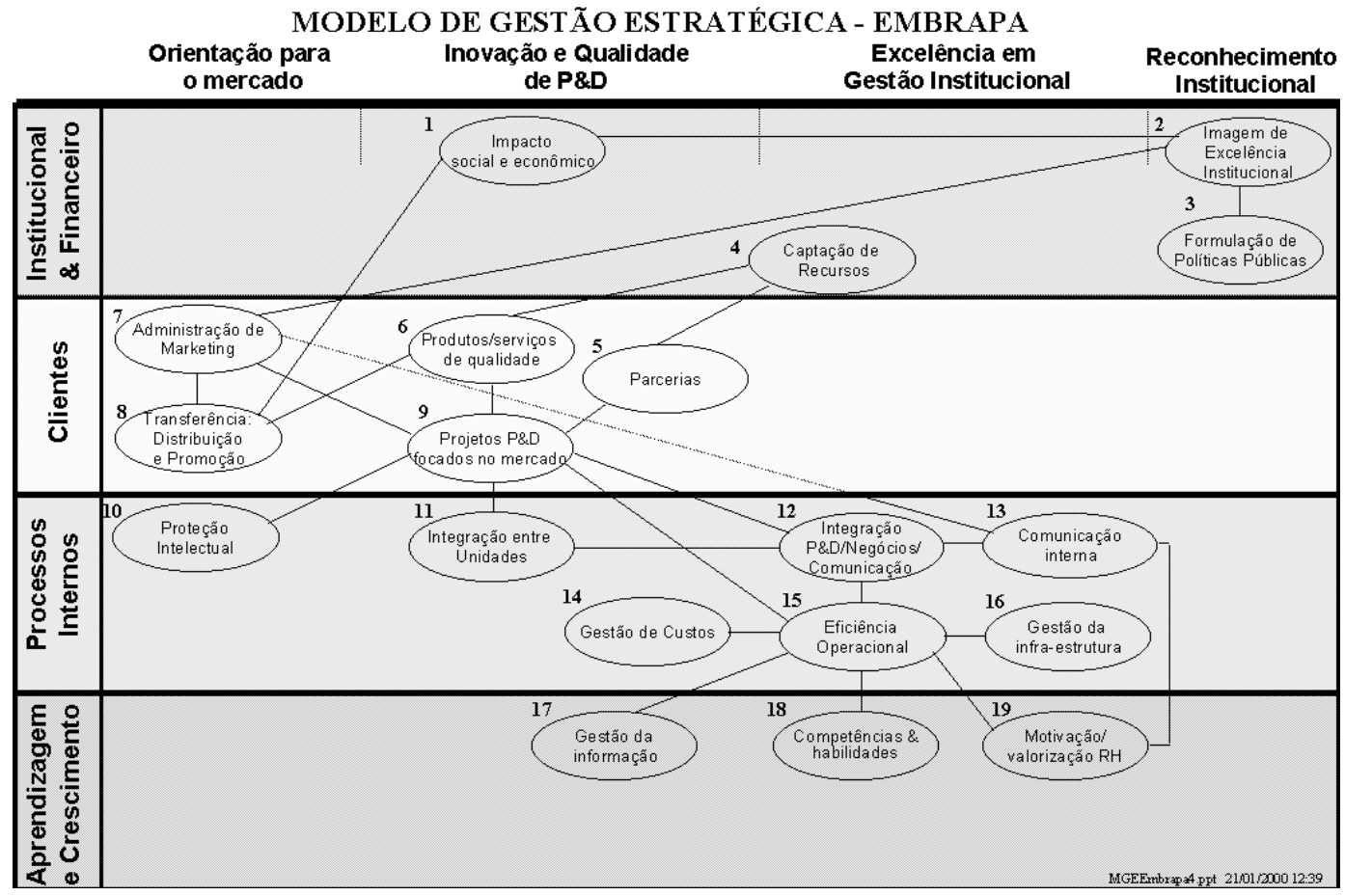

Figura 12 - Modelo de Gestão Estratégica Corporativo da Embrapa.

Fonte: EMBRAPA (2000b) 
Esse processo de mudança organizacional propõe o alinhamento de objetivos e metas com a estratégia de inovação da Empresa, e está fundamentado nos conceitos pilar do III Plano Diretor: missão, visão e objetivos globais. Dessa forma, o MGE busca o bom desempenho dos projetos, através da execução dos mesmos em equipe com rapidez, qualidade, produtividade, redução de despesas objetivando a plena satisfação dos clientes com os resultados alcançados.

\subsubsection{A ESTRUTURA ORGANIZACIONAL DA EMBRAPA}

Em conformidade à revisão bibliográfica e ao organograma da Embrapa Pecuária Sudeste, a estrutura organizacional reflete a maneira de como o trabalho é dividido em tarefas distintas, e está diretamente relacionada com o desempenho organizacional, uma vez que especifica a divisão do trabalho para que se possam alcançar os resultados e as metas propostas.

$\mathrm{Na}$ Embrapa, o tipo de estrutura das Unidades é o adhocrático, desdobrada em equipes de acordo com os projetos desenvolvidos e preocupada com a inovação, sempre focada no desenvolvimento de novos produtos e serviços. O chefe da Pesquisa e Desenvolvimento da Unidade coordena e avalia o desempenho dos projetos realizados.

A estrutura da Embrapa é o reflexo de suas estratégias, pois tenta criar uma integração de especialidades através de suas equipes de projetos para buscar competitividade e satisfação de seus clientes finais. 
Quanto à estrutura de cargos efetivos, é constituída por duas carreiras funcionais com quatro cargos, escalonados em níveis funcionais segundo os requisitos exigidos para sua ocupação.

Segundo o Quadro 5, as carreiras e cargos podem ser divididas em:

pesquisa e desenvolvimento, composta pelo cargo de pesquisador, em três níveis funcionais;

suporte à pesquisa e desenvolvimento, composta por cargos de nível técnico superior, com três níveis; cargos de assistente de operações, com dois níveis e auxiliar de operações, com três níveis.

$\begin{array}{cccc}\text { CARREIRA } & \text { CARGO } & \text { NÍVEL FUNCIONAL } & \text { ESCOLARIDADE } \\ \text { P\&D } & \text { Pesquisador } & \text { I } & \text { superior completo } \\ & & \text { II } & \text { mestrado } \\ & \text { Técnico Nível Superior } & \text { III II, III } & \text { superior completo } \\ \text { SUPORTE À P\&D } & \text { Assistente de Operações } & \text { I e II } & 2^{\circ} \text { grau } \\ & & \text { I } & 1^{\circ} \text { série } \\ & \text { Auxiliar de Operações } & \text { II } & 4^{\circ} \text { série }\end{array}$

Quadro 5- Descrição de carreiras e cargos da Embrapa 
O Departamento de Gestão de Pessoas (DGP), órgão central da administração da Embrapa, sediado em Brasília, tem como missão promover a gestão de pessoas, com excelência, respeito e ética, aplicando políticas e soluções inovadoras de seleção, desenvolvimento e manutenção do capital humano, com a finalidade de potencializar o comprometimento dos empregados, propiciar o desempenho diferencial e alcançar a missão institucional (EMBRAPA, 2003).

Dessa forma, a Embrapa Pecuária Sudeste administra seu pessoal com base na missão do DGP, e conta, em 2003, com 128 empregados. Seus resultados são avaliados por um sistema de avaliação de desempenho anual.

A avaliação de desempenho foca a orientação do comportamento dos empregados para alcançar as metas propostas no Plano Anual de Trabalho (PAT), com vistas a contribuir para a elaboração e/ou aprimoramento da política de $\mathrm{RH}$, a melhorar a desempenho dos empregados e a diagnosticar fatores que dificultam o alcance dos objetivos e das metas organizacionais.

A tendência atual da avaliação de desempenho na Embrapa é o sistema vinculado à gestão com foco em resultado, que visa recompensar mais do que punir e integrar os desempenhos individuais e de equipe.

O próprio Plano Diretor da Unidade propõe metas e indicadores de desempenho norteadores à inovação e à atividade dos pesquisadores e representam os conhecimentos, as metodologias, os processos e as tecnologias a serem obtidos no período e os meios de verificação.

No Plano Diretor constam, também, diretrizes estratégicas estabelecidas com base na missão, nos objetivos globais, na análise do ambiente externo e interno e nas 
características do enfoque de pesquisa de desenvolvimento em bovinocultura, enfatizando a intensificação dos sistemas de produção de carne e de leite com a utilização estratégica de plantas forrageiras tropicais.

Além dos projetos de pesquisa, podem-se destacar outros relacionados no Plano Diretor da Unidade:

gestão estratégica de processos, propondo a adoção de um modelo de gestão por processo e a busca de uma estrutura leve, ágil e concentrada na atividade-fim, a satisfação de clientes e a avaliação de resultados;

$>$ aprimoramento da política de recursos humanos, graças a uma política de fortalecimento das habilidades existentes e do desenvolvimento de novos valores, em busca da adequação do perfil dos recursos humanos aos desafios do realinhamento estratégico e das prioridades de P\&D.

Assim, pode-se perceber que a Embrapa valoriza seu talento humano e adota os novos paradigmas da gestão de recursos humanos, focando o desenvolvimento de competências individuais baseado nas estratégias traçadas para os períodos subseqüentes (Quadro 6). 


\begin{tabular}{|c|c|}
\hline SISTEMA & EMBRAPA \\
\hline Gestão de recursos humanos & estratégica \\
\hline Foco & tarefas/projetos \\
\hline Gestão de desempenho & $\begin{array}{c}\text { concentrada no resultado } \\
\text { do trabalho individual }\end{array}$ \\
\hline Carreira & rígida \\
\hline Desenvolvimento & multifuncionalidade \\
\hline Seleção & conhecimento \\
\hline Remuneração & Premiação por resultados \\
\hline
\end{tabular}

Quadro 6 - Mudanças da gestão de recursos humanos

\subsubsection{O SISTEMA DE AVALIAÇÃO DE DESEMPENHO DA EMBRAPA}

Em 1996, a alta direção da Embrapa frente ao desafio de aumentar a produtividade e de reduzir custos, priorizou dentre outras metas, o desenvolvimento de metodologias de avaliação de desempenho em diferentes níveis da organização - unidades, projetos e pessoas, definindo com maior clareza os objetivos básicos dos sistemas componentes da avaliação de desempenho empresarial (NADER, GUIMARÃES, e RAMAGEM, 1998).

Esses objetivos visam identificar as metas de produção, como essas metas estão sendo executadas (medidas de eficiência, como controle de custos, p. ex.) e quem está fazendo o que em diferentes processos, que resultam nos serviços e nos produtos da Embrapa. Assim, as perguntas quem faz o quê e como faz vêm orientando o desenvolvimento de metodologias para a avaliação de desempenho de unidades, projetos de pesquisa e pessoas (NADER, GUIMARÃES e RAMAGEM, 1998). 
No entanto, a Embrapa tem um histórico de experiências de avaliação de desempenho de empregados com grandes dificuldades e problemas metodológicos. Passou por uma série de fases de avaliação até chegar na metodologia atual que é o SAAD-RH, o Sistema de Planejamento, Acompanhamento e Avaliação de Resultados do Trabalho Individual.

Nesta trajetória, o primeiro sistema de avaliação de desempenho da Embrapa foi instituído em 1975 e utilizado até 1979. Todo o pessoal técnico-científico e administrativo era submetido a periódica avaliação de desempenho, visando à melhoria dos processos e dos impactos por eles gerados. O sistema possuía múltiplos objetivos, tais como definir políticas e decisões relativas ao gerenciamento dos recursos humanos da empresa, explicitar papéis que o empregado deveria assumir na execução de seu trabalho, melhorar sua integração e desenvolvimento, detectar potencialidades e conscientizar avaliador e avaliado de suas responsabilidades (NADER, GUIMARÃES e RAMAGEM, 1998).

A metodologia desse sistema consistia no estabelecimento de grupos de avaliação determinados pelos cargos (pesquisadores, gerência, apoio à pesquisa, administração geral) aos quais se aplicava o mesmo conjunto de indicadores de desempenho ou os mesmos formulários. Usavam-se dois formulários: um de avaliação e outro de auto-avaliação (NADER, GUIMARÃES e RAMAGEM, 1998).

O primeiro era usado pelo supervisor do empregado, que exercia o papel de avaliador. Continha uma escala de 6 pontos - de insuficiente a excelente, 16 indicadores de desempenho e um indicador de desempenho global, e mais um campo em que poderiam ser indicados necessidades de treinamento, potencial do empregado ou desvios de função. O outro formulário, quase idêntico ao primeiro, (sem o campo de informações complementares) era usado para a auto-avaliação do empregado. O processo de avaliação era realizado anualmente e aplicado em todos os empregados, com um mínimo de três meses de trabalho (NADER, GUIMARÃES e RAMAGEM, 1998). 
O segundo sistema de avaliação de desempenho da Embrapa foi instituído em 1983 e utilizado até 1985, e introduziu o conceito de acompanhamento, visando estimular o empregado a utilizar suas melhores habilidades e capacidades, bem como ajustá-lo à função, ao grupo e à Empresa. Os objetivos desse sistema eram definir o grau de contribuição de cada empregado, promover o seu autodesenvolvimento, identificar o potencial de trabalho de cada empregado, propor planos de ação para desempenhos insatisfatórios, oferecer subsídios para a remuneração, indicar ao empregado suas potencialidades e promover a coesão social (NADER, GUIMARÃES e RAMAGEM, 1998).

Os instrumentos usados eram um caderno com a descrição de todos os cargos existentes na empresa e um formulário dividido em três partes. A primeira parte destinavase à auto-avaliação do empregado com base na descrição de seu cargo e o apoio que ele necessitava para executar melhor sua atividade. A segunda parte, com os mesmos itens da anterior, era para a avaliação do supervisor. A terceira parte era preenchida pelo supervisor em conjunto com o empregado (NADER, GUIMARÃES e RAMAGEM, 1998).

No período de 1986 a 1994, a Embrapa não utilizou sistemas formais de avaliação de desempenho do pessoal, em razão da dificuldade de encontrar um sistema que apresentasse mais benefícios do que efeitos colaterais indesejáveis e da ausência de decisão política da Diretoria da Embrapa (NADER, GUIMARÃES e RAMAGEM, 1998).

O terceiro sistema de avaliação de desempenho da Embrapa foi estabelecido no final de 1994, um Sistema de Planejamento, Acompanhamento e Avaliação de Resultados do Trabalho Individual da Embrapa, denominado de SAAD-RH. Esse sistema está diretamente ligado às metas traçadas no Sistema Embrapa de Gestão (SEG) e ao Plano Diretor (PDU) da unidade de pesquisa. As atividades e os resultados nele previstos decorrem de programas de trabalho das unidades, dos setores e das áreas e de projetos e planos de ação (subprojetos) (NADER, GUIMARÃES e RAMAGEM, 1998). 
O SAAD-RH é um instrumento para ser usado no dia-a-dia, tanto pelo empregado quanto pelo supervisor. A programação de trabalho, o cronograma de entrega de resultados, o mapa de produção e a direção para a realização dos trabalhos que são necessários para a Embrapa, num determinado período (EMBRAPA, SAAD-RH Passo a Passo, 1997).

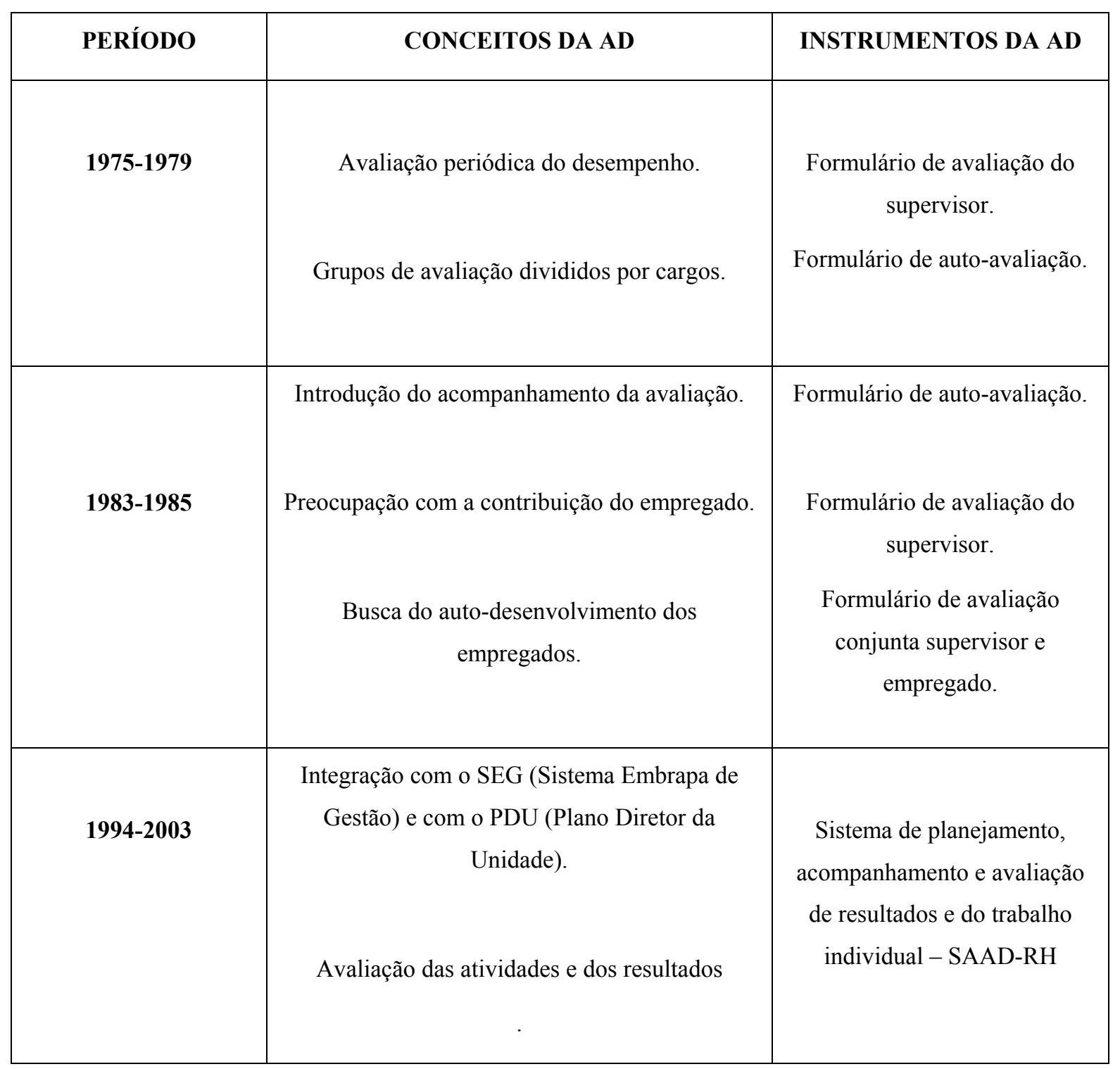

Quadro 7 - Histórico da Avaliação de Desempenho (AD) da Embrapa 


\subsubsection{O SISTEMA DE PLANEJAMENTO, ACOMPANHAMENTO E AVALIAÇÃO DE RESULTADOS E DO TRABALHO INDIVIDUAL}

O Sistema de Planejamento, Acompanhamento e Avaliação de Resultados do Trabalho Individual da Embrapa - SAAD-RH tem como premissas básicas (NADER, GUIMARÃES e RAMAGEM, 1998):

ser implantado e operacionalizado de maneira participativa;

conciliar os objetivos e as prioridades da Empresa com os interesses e as necessidades dos empregados;

$>$ integrar-se à filosofia de desenvolvimento humano organizacional da Embrapa;

$>$ respeitar as peculiaridades e as especificidades de cada unidade da organização.

O objetivo geral desse sistema é acompanhar e avaliar o empregado, no cumprimento de ações estabelecidas para o alcance da missão da sua unidade de lotação. Quanto aos objetivos específicos busca orientar decisões gerenciais sobre as necessidades de treinamento; planejar as atividades do empregado; premiar e promover na carreira; punir mediante advertência, suspensão e demissão os empregados; indicar necessidades de movimentação e readaptação funcional de empregados; servir de mecanismo reorientador das políticas e diretrizes de recursos humanos da empresa; identificar as condições de trabalho do empregado, capazes de influenciar no seu desempenho; promover a interação entre empregado e supervisor e incentivar o planejamento e o desenvolvimento de carreira (NADER, GUIMARÃES e RAMAGEM, 1998). 
O SAAD-RH mudou o foco da avaliação do empregado para o resultado do trabalho, buscando identificar as competências importantes para a pesquisa em conjunto com o alcance das metas propostas. Assim, os critérios de desempenho são indicadores de tarefa e estão relacionados às metas de produção das unidades, que derivam das metas perseguidas pela organização (NADER, GUIMARÃES e RAMAGEM, 1998).

No SAAD-RH há o planejamento mais explícito das atividades:

O que se espera do produto do trabalho;

Como o produto deve ser apresentado, qual o padrão de desempenho esperado;

Em que prazo o produto deve ser apresentado;

Feedback dos resultados do trabalho.

No entanto, desde que foi implementado em 1994, o SAAD-RH vem sofrendo alterações para melhorar sua metodologia, tentando conscientizar seus participantes da necessidade do diálogo período - acompanhamento das atividades e, da avaliação imparcial e especifica das atividades planejadas em relação à disponibilidade dos meios para a execução dessas atividades.

O SAAD-RH busca estar em conformidade com o Plano Anual da Unidade (PAT) e Plano Diretor da Unidade (PDU), por meio da descrição das atividades que serão avaliadas no SAAD-RH é possível direcionar os esforços em busca da realização das metas propostas no início de cada ano.

O SAAD-RH envolve 3 grandes áreas (EMBRAPA, 1997):

o planejamento que deve resultar no plano de trabalho a ser executado pelo empregado, isto é, suas atividades programadas e os resultados esperados. 
o acompanhamento que é a troca de informações entre supervisor e empregado, visando identificar problemas de execução ou ausência de meios que estejam interferindo na obtenção dos resultados. Cabe a ambos identificar as ações corretivas a serem adotadas.

a avaliação que é o ato de comparar o executado com o planejado, dando e recebendo informações sobre a execução da atividade e o resultado obtido.

Vê-se que o SAAD-RH compreende o chamado "ciclo administrativo", composto das funções de planejamento, organização, coordenação e controle. Nos casos de discordância entre as avaliações do supervisor e do empregado, a chefia da Unidade atua como juiz do processo (EMBRAPA, 1997).

No caso de persistir a discordância entre as avaliações e se o supervisor for o próprio chefe da Unidade, o assunto é submetido a um Comitê do SAAD-RH que procede a análise da situação e ouvirá as partes interessadas. O Comitê dará conhecimento ao interessado sobre o resultado da análise procedida, por escrito, e no prazo de 5 dias, a contar do recebimento da solicitação (EMBRAPA, 1997).

O Comitê do SAAD-RH é composto por sete pessoas escolhidas pela Chefia - uma pessoa do RH, dois pesquisadores, um laboratorista, duas pessoas do campo e uma de serviços auxiliares.

No entanto, na prática diária, essa postura de acompanhar o alcance dos resultados não se faz tão presente quanto deveria. A avaliação de desempenho é feita anualmente e a fase de acompanhamento é feita quase que conjuntamente com a própria avaliação.

O sistema de avaliação de desempenho divide os 128 empregados da Unidade em agrupamentos, de acordo com a finalidade das atividades exercidas e com as competências necessárias para o exercício de cada cargo (ANEXO B). 
O formulário do SAAD - RH chama-se PARTI - Planejamento, Acompanhamento e Avaliação de Resultados do Trabalho Individual, o qual deve ser preenchido por todos os empregados da Embrapa, em conjunto com seus supervisores imediatos. É no PARTI que se estabelece o plano individual de trabalho de cada empregado (ANEXO C).

O planejamento das atividades do empregado deve ser feito em função das metas da unidade, área ou setor onde o empregado trabalha, projeto (definido internamente como plano de ação) de responsabilidade da sua unidade de lotação.

O SAAD-RH reflete os desmembramentos do Plano Anual de Trabalho (PAT) planejado pela unidade com base no MGE, e é através dele que serão monitorados e corrigidos os desvios com relação às metas pré-estabelecidas (SENTANIN, 2003), conforme apresentado na Figura 13.
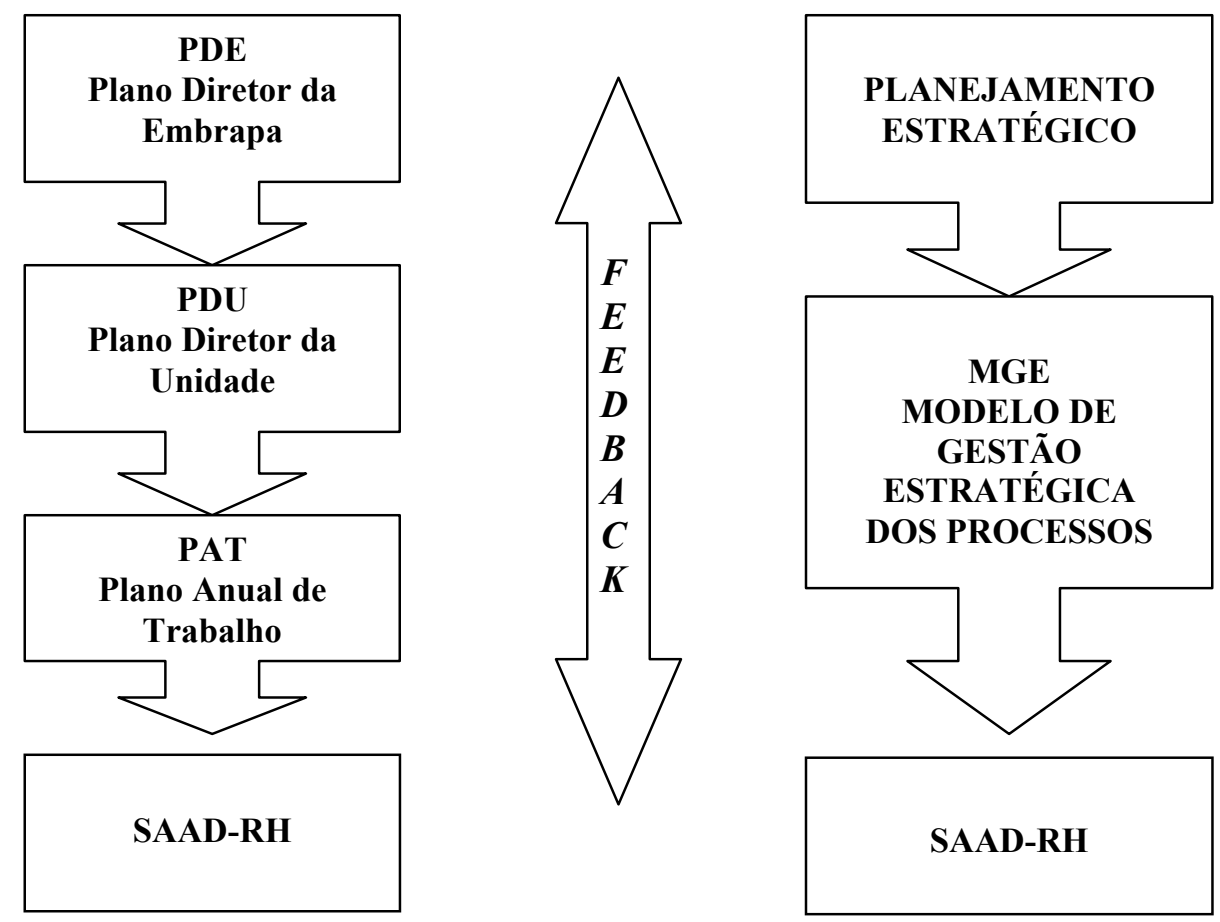

Figura 13 - Processo de Gestão Estratégica do Desempenho na Embrapa 
A avaliação de desempenho deve considerar os resultados do trabalho e as competências e os comportamentos pessoais, à medida que estejam influindo nesses resultados. O SAAD-RH considera para efeito de formação de Escore Final da Avaliação EAF, 90\% relativo a avaliação de resultados feita pelo supervisor e $10 \%$ relativo à avaliação de aspectos comportamentais, feita pela chefia geral da Unidade, ouvidos os respectivos supervisores. Esses $10 \%$ foram determinados para corrigir possíveis distorções da avaliação do supervisor, mas, no entanto, pode agravá-las ainda mais.

Em 1997, a Embrapa divulgou com mais intensidade o SAAD-RH. Foram distribuídos nas Unidades guias para conscientização e uniformização da avaliação de desempenho, fitas de vídeo, palestras, etc. Assim, propôs algumas competências para o uso do SAAD-RH:

comunicação, procurar entender e se fazer entendido;

relacionamento, participar de forma cooperativa e interagir com a equipe;

negociação, entendimento, estabelecer planos de trabalho e metas;

retroalimentação (feedback), dar e receber informações, criando um ambiente favorável ao trabalho.

Na Embrapa Pecuária Sudeste estão sendo organizadas, pelo Comitê do SAAD e pelo Setor de Recursos Humanos, algumas atividades de conscientização e divulgação dos critérios do SAAD-RH, com a finalidade de diminuir a resistência das pessoas quanto ao impacto da avaliação de desempenho. O projeto das atividades foi iniciado com reuniões de trabalhadores dos agrupamentos de campo para familiarizá-los de todas as fases do SAAD$\mathrm{RH}$, principalmente a do acompanhamento.

Nessas reuniões identificam-se as principais reclamações e sugestões dos trabalhadores relacionadas ao SAAD-RH e propõe-se a mudança cultural da necessidade do diálogo entre supervisor e empregado quanto ao desenvolvimento de importantes 
competências às tarefas em questão e, da disposição do Comitê do-RH para resolver possíveis conflitos.

O Comitê do SAAD-RH pretende organizar novas reuniões com outros agrupamentos de avaliação, visando ao mesmo objetivo das anteriores. Assim, os empregados poderão entender a finalidade desse sistema de avaliação de resultados, uma vez que este influi no pagamento de bônus por resultados, premiação por excelência, progressão salarial e promoção por mérito, desenvolvimento dos empregados e penalidades.

\subsubsection{O SAAD-RH E A GESTÃO DE COMPETÊNCIAS}

A gestão de competências na Embrapa, cumprindo o ciclo de formação de competências, orienta as decisões gerenciais, os processos de desenvolvimento profissional, o planejamento das atividades e os subsistemas de recursos humanos. Está integrada com o sistema de avaliação de desempenho e com o planejamento estratégico.

Dentro da estrutura de cargos apresentada, a Embrapa gerencia seus recursos humanos aliando o alcance das metas propostas no Plano Anual de Trabalho (PAT) com a negociação das atividades propostas no SAAD-RH de cada empregado.

Com a nova Constituição Federal de 1988, a seleção de pessoal na Embrapa passou a ser feita somente por aprovação em concurso público, condicionada à existência de vaga no cargo da Unidade solicitante. O empregado admitido tem ciência de que pode ser transferido para qualquer outra Unidade, se for necessário à Empresa e de que sua produção intelectual será propriedade da Embrapa enquanto seu contrato estiver vigente.

A Embrapa mantém programas de treinamentos formais e não formais de aperfeiçoamento do empregado, visando atender às demandas atuais e potenciais da 
Empresa. Nesse sentido, os resultados do SAAD-RH são usados para capacitação e reciclagem dos empregados.

A cada ano a Embrapa destina recursos financeiros equivalentes a $1 \%$ da folha de pagamento de cada Unidade para promoção e progressão salarial.

A promoção consiste na mudança do enquadramento funcional do empregado, de um nível para o outro imediatamente superior, dentro do mesmo cargo. A concessão de promoção resulta do mérito do empregado e considera as metas e os resultados alcançados e, seu crescimento profissional.

A progressão salarial por antigüidade refere-se a mudança de enquadramento salarial para uma referência salarial superior, dentro do mesmo nível funcional do cargo, por, no mínimo, 24 meses de serviço, sem receber promoção ou progressão salarial. Já a progressão salarial por mérito somente ocorre entre níveis funcionais de um mesmo cargo.

O reenquadramento funcional ou mudança de cargo só é possível mediante aprovação em concurso público.

A cada dois anos, nas Unidades são realizados os processos de progressão salarial e de promoção. Durante o período de 10 anos, os pontos recebidos pelo empregado, em decorrência de análise de méritos, são somados, acumulados e atualizados, anualmente.

A premiação pecuniária por resultados decorre de contribuição individual do empregado e das equipes do trabalho, em relação ao cumprimento das metas de desempenho de cada Unidade, podendo ser de dois tipos: 
bônus individual por resultados, o valor anual, não integrante da remuneração, pago em dinheiro, em uma única parcela, é calculado em função da contribuição do empregado no cumprimento das metas de sua unidade.

bônus por resultado de equipe, o valor anual, não integrante da remuneração, pago em dinheiro, em uma única parcela, limitado a um salário-base do empregado, acrescido do adicional de tempo de serviço e do adicional de titularidade (quando apropriado) para cada projeto ou ação premiados.

O pagamento de bônus por resultados é feito aos empregados que se destacam pelos resultados alcançados. Estes recebem premiação na forma de bônus, calculado com base na classificação obtida pela sua unidade no Sistema de Avaliação de Unidades.

Esse sistema de recompensa na Embrapa baseia-se na análise de dois fatores:

escore do SAAD-RH, com peso variável entre $60 \%$ a $90 \%$,

avaliação dos aspectos comportamentais (AC), com peso variável entre $40 \%$ a $10 \%$, a ser feita a cada semestre pelo supervisor imediato de cada empregado.

A premiação por excelência é oferecida aos destaques como forma de reconhecimento do seu trabalho, acontece, desde 1999, sempre nos anos em que não há recompensas por progressão salarial ou promoção.

Em termos institucionais, a melhoria dos processos é recompensada no Sistema de Avaliação das Unidades (SAU), no qual todas as Unidades estabelecem, anualmente, como meta qualitativa a melhoria de três processos; e também na Premiação Nacional das Equipes, que, dentro de cada categoria específica, premia as cinco melhores equipes que se destacaram na análise e melhoria de processos (SENTANIN, 2003). 
Dessa forma, a Embrapa busca o compartilhamento de experiências entre as Unidades, a fim de otimizar a utilização de recursos e de desenvolver competências individuais, concentrando seu foco nos processos e projetos de pesquisa de maior relevância.

As penalidades aos funcionários que apresentam, continuamente, baixos resultados de trabalho variam desde penalidades sob a forma de advertência, suspensão até a demissão.

\subsubsection{O PERFIL DO PESQUISADOR DA EMBRAPA}

Pode-se dizer, genericamente, que o perfil do pesquisador da Embrapa está consolidado no desenvolvimento de projetos de pesquisa em conformidade com o Plano Diretor da Unidade e com a missão da Embrapa. Dessa forma, o pesquisador transfere os resultados de sua pesquisa para os sistemas de produção agropecuária.

O pesquisador segue os valores enfatizados na cultura da Embrapa Pecuária Sudeste. Entre eles estão:

$>$ cultivar e premiar a criatividade;

$>$ buscar eficiência e eficácia, desenvolver ações com foco na obtenção de resultados e soluções, com custos compatíveis e competitivos;

planejar o futuro, posicionando estrategicamente os recursos e as capacidades;

estar comprometido com a honestidade e a conduta ética, valorizando o ser humano e tratando todos os grupos da sociedade com atenção; 
procurar atender às especificidades das demandas da clientela, seguindo os princípios de qualidade total;

incentivar a liderança, na geração, adaptação e transferência de conhecimentos, produtos, serviços e tecnologias;

encorajar parcerias com outras organizações e indivíduos;

manter colaboração global, em assuntos da ciência e tecnologia do agronegócio da bovinocultura;

buscar o rigor científico, pautar as ações de P\&D pelo método científico, pela exatidão e pela precisão de procedimentos em todas as etapas do processo, não tolerando viés nos resultados;

apoiar equipes que abordam os problemas de modo holístico, atentas para as implicações finais de seu trabalho.

As principais competências do pesquisador da Embrapa estão diretamente ligadas com a missão e os valores desenvolvidos pela empresa (III Plano Diretor da Unidade, 2000a). Entre elas estão:

$>$ fornecer a base de conhecimentos que permita o surgimento e fortalecimento de empresas de base tecnológica em bovinocultura e plantas forrageiras;

monitorar e analisar o comportamento do mercado do agronegócio e as principais tendências;

$>$ utilizar conhecimentos para identificar padrões de qualidade dos produtos de bovinocultura a partir de métodos científicos;

$>$ desenvolver novas práticas e tecnologias que promovam o desenvolvimento e a conservação de base de recursos naturais, balanceando eficiência produtiva e qualidade ambiental.

Por meio do SAAD-RH, as atividades dos pesquisadores podem ser direcionadas para o foco estratégico proposto pela unidade no Plano Anual de Trabalho (PAT). O índice 
de Nível de Impacto de Atividades (NIA) mais altos é atribuído às atividades de maior importância para a Unidade.

No SAAD-RH de um pesquisador constam itens de avaliação relacionados com (ANEXO D):

atividades propostas no Sistema Embrapa de Gestão (SEG) e no Plano Anual de Trabalho (PAT);

> atividades referentes à produção de publicações, à transferência de tecnologia e promoção da imagem e ao desenvolvimento de tecnologias, produtos e processos;

$>$ outras atividades.

As atividades de transferência de tecnologia e de promoção de imagem da Empresa estão relacionadas com a elaboração, avaliação e publicação de artigo científico ou capítulo de livro, de sistema de produção, artigo em anais científicos, de nota técnica, boletim de pesquisa e de resumos, bem como a participação em palestras, conferências, seminários internos, comissões organizadoras e cursos de pós-graduação.

O acompanhamento de projetos, a participação, a elaboração e a execução de plano de ação (subprojeto) são atividades relacionadas com o SEG e o PAT. Participar de comitês ou comissões permanentes ou temporárias, exercer a responsabilidade por e executar ação de suporte à pesquisa, e elaborar projeto de captação de recursos para instituição financeira ou programa de fomento também são atividades pertinentes aos pesquisadores da Embrapa. 


\subsection{CONSIDERAÇÕES FINAIS}

No estudo de caso é apresentado o sistema de avaliação de desempenho utilizado na Embrapa, o SAAD-RH, um sistema de planejamento, acompanhamento e avaliação de resultados e do trabalho individual. O objetivo principal é apontar a importância de tal sistema para o gerenciamento das competências dos pesquisadores voltadas às estratégias de inovação.

O sistema de avaliação de desempenho, além de ser um instrumento para reconhecimento dos resultados alcançados, também é usado para identificar competências humanas importantes à pesquisa e nortear as práticas de seleção, treinamento e recompensa das Unidades de Pesquisa da Embrapa.

Preocupando-se em atender as demandas de seus clientes, a Embrapa traça seus objetivos estratégicos e os repassa às suas Unidades de Pesquisa, que os incorporam ao Plano Anual de Trabalho (PAT). Por sua vez, as Unidades estabelecem no SAAD-RH dos pesquisadores as atividades importantes ao cumprimento das metas propostas, e conseqüentemente, desenvolvem novas práticas e tecnologias. 


\section{CONCLUSÃO}

Apresentou-se neste trabalho a gestão de competências em uma empresa de pesquisa e desenvolvimento, com o objetivo de analisar a gestão de competências como elemento viabilizador das estratégias de pesquisa e desenvolvimento de produtos, enfocando a avaliação de desempenho como uma ferramenta importante na identificação de competências humanas.

Neste Capítulo são analisados as particularidades, os fatores favoráveis e as limitações da gestão de competências na Embrapa.

\subsection{PARTICULARIDADES DA GESTÃO DE COMPETÊNCIAS DA EMBRAPA}

A partir da década de 90, a Embrapa passou a se preocupar mais com sua formulação estratégica e com o foco na demanda de seus clientes externos, a fim de se manter competitiva e estar sempre a frente na geração de tecnologia agropecuária.

A gestão de competências na Embrapa é realizada com base na identificação de competências individuais, através da avaliação de desempenho por resultado do trabalho individual, e com base nas suas estratégias de inovação, refletidas em sua estrutura organizacional formulada por processos e projetos de pesquisa.

A avaliação de desempenho na Embrapa caracteriza-se por um histórico de experiências com grandes dificuldades e problemas metodológicos. Conforme apontado em vários depoimentos, nas entrevistas realizadas, um fator determinante para a consolidação de SAAD-RH foi o comprometimento pessoal do antigo Presidente da Empresa (período de 
1998-2002) com a avaliação de desempenho. Acredita-se que sem esse comprometimento da alta administração, talvez a avaliação e a gestão de competências não estariam relacionadas com a estratégia organizacional da Empresa.

\subsection{FATORES QUE CONTRIBUÍRAM PARA A GESTÃO DE COMPETÊNCIAS}

A Embrapa, com a pretensão de otimizar seus recursos e aumentar a velocidade de resposta aos seus clientes, instituiu algumas mudanças organizacionais, apontadas anteriormente, que facilitaram a gestão de competências. Entre os fatores que contribuíram para a gestão de competências podem-se destacar:

$>$ a possibilidade de crescimento profissional do empregado, identificando necessidades de treinamento e redirecionando atividades e processo internos;

$>$ os programas de recompensa por resultado alcançado, individual, por equipe ou por Unidade, possibilitam o aumento da produtividade dos empregados e a busca contínua de novas tecnologias;

$>$ o incentivo, pelo SAAD-RH, da comunicação entre supervisor e subordinado através do diálogo de acompanhamento das atividades realizadas.

\subsection{LIMITAÇÕES DA GESTÃO DE COMPETÊNCIAS}

Pode-se afirmar que a maioria das limitações da gestão de competências na Embrapa está relacionada com questões de ordem metodológica e de ordem cultural. 
Quanto aos aspectos metodológicos, as principais limitações referem-se à complexidade dos procedimentos e instrumentos de avaliação de desempenho e à falta de clareza sobre o que está sendo avaliado. A metodologia de avaliação da Embrapa foi estruturada como um processo focado nos resultados, baseados em objetivos e metas organizacionais refletidos nos projetos de trabalho e nas responsabilidades do empregado, segundo o cargo e as competências de cada um. Nesse sentido, a responsabilidade pela avaliação cabe aos ocupantes de funções de supervisão que são, em ultima instância, responsáveis pelo alcance das metas estabelecidas pela Empresa (GUIMARÃES; LEITÃO e LOURENÇO, 1999, p.91).

É conveniente que a Embrapa assumia sua responsabilidade institucional para garantir a formulação metodológica de sua avaliação de desempenho, e conseqüentemente, a integração da gestão e competências com suas estratégias de inovação.

Apesar de haver uma integração entre a avaliação de desempenho com os planos estratégicos traçados pela Empresa, a gestão de competências, ainda, é focada no indivíduo com base nas suas tarefas e não no indivíduo inserido no seu contexto social coletivo, conforme apontado por Dejours (1997), Zarifian (2001) e Ramos (2001).

A noção de competência da Embrapa reconhece apenas o âmbito das habilidades (saber como fazer) e do conhecimento (informações e experiências), esquecendo-se do âmbito das atitudes (querer fazer). A Empresa pauta-se apenas pela competência reconhecida pela titulação, não incluindo a iniciativa e as responsabilidades diante das situações complexas. Não foca a busca e o desenvolvimento de competências direcionadas para projetos específicos nem para a integração e o trabalho em equipe.

A avaliação de desempenho não tem a dimensão de equipe nem o conceito de feedback estruturado da avaliação 360 graus (REIS, 2000), ainda é somente o superior que avalia seus subordinados. Os resultados do SAAD-RH contribuem para a formulação do planejamento estratégico da Embrapa, mas não há nenhum mecanismo de avaliação dos funcionários em relação à empresa, aos seus superiores ou ao clima organizacional. 
Quanto aos aspectos culturais, evidencia-se grande resistência e descrença com os sistemas de avaliação de desempenho e com o desenvolvimento de competências humanas, apesar dos empregados da Embrapa já estarem familiarizados com os sistemas de avaliações de projetos de pesquisa.

Considerando-se essa descrença, os avaliadores não exercitam o papel de planejamento e de acompanhamento do trabalho individual. "Há sempre alguma tarefa mais importante e mais urgente do que 'sentar-se com alguém' para planejar ações que dizem respeito ao trabalho individual e ao desempenho deste" (NADER, GUIMARÃES e RAMAGEM, 1998, p.17).

A falta do repasse de informações, ao empregado, sobre as obrigações que a organização espera que ele cumpra e sobre os requisitos dos resultados que deve apresentar, acarreta a desmotivação dos empregados quanto à gestão de competências.

Conforme os depoimentos colhidos, a resistência maior em relação à gestão de competências é da parte dos pesquisadores. A maioria deles são doutores, conhecendo métodos e referenciais teóricos que, segundo suas opiniões, seriam suficientes para a realização de suas atividades. Não se questiona de maneira alguma a necessidade de desenvolvimento de competências individuais.

A gestão de competências orienta os gerentes quanto às necessidades de recursos e de treinamento para a realização de seus processos e de suas atividades, bem como, norteia a organização quanto às suas políticas e diretrizes estratégicas.

O Quadro 8 confronta os referenciais teóricos com a prática da Embrapa. Abordamse a presença dos elementos da competência - habilidades, atitudes, conhecimento e produção e entrega, o modelo de avaliação de desempenho e a integração estratégica dos processos com a gestão de recursos humanos. 
ELEMENTOS DA GESTÃO DE COMPETÊNCIAS NA EMBRAPA
PRESENTE

AUSENTE

ação de competências por habilidade

Formação de competências por atitude

Formação de competências por conhecimento

Formação de competências por produção e entrega

Avaliação de desempenho por resultados

Avaliação de desempenho 360 graus

Integração da avaliação de desempenho com o

planejamento estratégico

Integração da avaliação de desempenho

com os subsistemas de recursos humanos
$\mathrm{X}$

$\mathrm{X}$

$\mathrm{X}$

$\mathrm{X}$

$\mathrm{X}$

$\mathrm{X}$

$\mathrm{X}$

Quadro 8 - Elementos da gestão de competências na Embrapa

Uma abordagem coletiva e social da gestão de competências inclui o âmbito das atitudes para que haja integração entre o planejamento, acompanhamento, avaliação de desempenho, feedback dos dados levantados e reciclagem dos processos da organização. É justamente este feedback, quando bem gerido, que faz a diferença, não só pela identificação das competências individuais necessárias a cada atividade, mas pela possibilidade de compartilhar o crescimento profissional com as inovações e estratégias competitivas da empresa. O feedback aliado à estratégia da empresa possibilita uma maior integração entre todos os seus níveis organizacionais. 


\subsection{CONSIDERAÇÕES FINAIS}

Esta dissertação preocupou-se em apresentar a gestão de competências na Embrapa dentro de um contexto histórico abrangente, apontando seu sistema de avaliação de desempenho como instrumento para identificar competências humanas importantes ao alcance de suas competências estratégicas e para nortear suas práticas de seleção, treinamento e recompensas.

Este trabalho abre perspectivas o desenvolvimento de estudos que busquem uma maior compreensão do relacionamento entre a gestão de competências e a avaliação de desempenho, uma vez que na literatura não se discute o processo de formação de competências.

Propõem-se estudos de caso e revisões bibliográficas sobre o processo de formação de competências, em específico do ponto de vista cotidiano e operacional. Sugerem-se a realização de estudo sobre a tipologia, os elementos da competência e a prática da gestão de competências nas organizações além da visão unilateral da instituição. 


\section{REFERÊNCIAS}

AQUINO, C.P. (1980). Administração de recursos humanos. São Paulo, Atlas.

BRANDÃO, H.P.; GUIMARÃES, T.A. (2001). Gestão de competências e gestão de desempenho: tecnologias distintas ou instrumento de um mesmo constructo? Revista de Administração de Empresas, São Paulo, v. 41, n. 1, p. 8-15, jan/mar.

BECKER, H.S. (1994). Métodos de pesquisa em ciências sociais. São Paulo: Hucitec.

BORRÁS, M.A.A. (2000). Recursos humanos para o agrobusiness brasileiro: perfil da oferta de profissionais no mercado nacional. 271p. Dissertação (Mestrado). Departamento de Engenharia de Produção, Universidade Federal de São Carlos, São Carlos. 2000.

CANÊDO, L.B. (1987). A evolução industrial. São Paulo: Unicamp.

CHIAVENATO, I. (2002). Recursos humanos. São Paulo: Atlas. . (1996). Gerenciando pessoas: o passo decisivo para a administração participativa. 2. ed. São Paulo: Makron Books.

CONDE, L.P. (2001). Gestão de competências como prática de recursos humanos nas organizações: estudo de caso em uma empresa de tecnologia da informação. 171p. 
Dissertação (Mestrado) - Faculdade de Economia e Administração, Universidade de São Paulo, São Paulo. 2001.

DAVENPORT, T.H.; PRUSAK, L. (1998). Conhecimento empresarial: como as organizações gerenciam o seu capital intelectual. Rio de Janeiro: Campus.

DEJOURS, C. (1997). O fator humano. Rio de Janeiro: Fundação Getúlio Vargas.

DE LA POZA, J. (1998). La selección de recursos humanos basada en las competências. Propuestas de um modelo para la selección de recursos humanos. Revista de la asociación española de dirección de personal. n. 4, marzo.

DEVANNA, M.A., FOMBRUN, C.J. \& TICHY, N.M. (1984). A framework for strategic human resource management. In: FOMBRUN, C.J., TICHY, N.M. \& DEVANNA, M.A., coords. Strategic human resource management. New York: Jonh Wiley.

DUTRA, J.S. (1996). Administração de carreiras: uma proposta para repensar a gestão de pessoas. São Paulo: Atlas.

DUTRA, J.S. (2001). Gestão de pessoas com base em competências. In: DUTRA, J. S. (Coord.) Gestão por competências. São Paulo: Gente, p.25-43.

EBOLI, M. Um novo olhar sobre a educação corporativa - desenvolvimento de talentos no século XXI. In: DUTRA, J. S. (Coord.) Gestão por competências. São Paulo: Gente, 2001, p.109-128. 
EMPRESA BRASILEIRA DE PESQUISA AGROPECUÁRIA (2003).Brasília. Disponível em: <http://www.embrapa.br>. Acesso em: 22 ago. 2003.

. (2000a). Embrapa Pecuária Sudeste. III Plano Diretor. São Carlos.

Brasília.

. (2000b) Secretaria de Administração Estratégica. Modelo de Gestão Estratégica. . (2000c) Resolução Normativa n 17/2000. Brasília.

. (1997) Departamento de Recursos Humanos. SAAD-RH Passo a passo. Brasília.

FERREIRA, A.B.H. (1995). Novo Dicionário Aurélio. Rio de Janeiro: Nova Fronteira.

FISCHER, A.L. (1998). A constituição do modelo competitivo de gestão de pessoas no Brasil: um estudo sobre as empresas consideradas exemplares. 392p. Tese (Doutorado). Faculdade de Economia, Administração e Contabilidade, Universidade de São Paulo, São Paulo. 1998.

FLEURY, A.; FLEURY, M.T.L. (2000). Estratégias empresariais e formação de competências. São Paulo: Atlas.

FLEURY, A.; FLEURY, M.T.L. (1997). Aprendizagem e inovação organizacional: as experiências de Japão, Coréia e Brasil. São Paulo:Atlas, 1995.

GUIMARÃES, T.A; LEITÃO, J.S.S.; LOURENÇO, R.L.R. (1999). Avaliação de desempenho baseada em resultados em organização de pesquisa e desenvolvimento: a 
percepção de pesquisadores sobre sua finalidade, objetivos e limitações. Revista de Administração de Empresas, São Paulo, v. 34, n. 3, p. 83-94, jul./set.

HAMEL, G.; PRAHALAD, C.K. (1995). Competindo pelo futuro. Rio de Janeiro: Campus.

HAMPTON, D.R. (1996). Administração Contemporânea. São Paulo: Makron-Books.

HIPÓLITO, J.A.M. (2001). Tendências no campo da remuneração para o novo milênio. In: DUTRA, J.S. (Coord.) Gestão por competências. São Paulo: Gente. p.71-94.

KAPLAN, R.S.; NORTON, D. (1997). A estratégia em ação: balanced scorecard. Rio de Janeiro: Campus.

KING, A.; FOWLER, S.W.; ZEITHAML, C.P. (2002). Competências organizacionais e vantagem competitiva: o desafio da gerência intermediária. Revista de Administração de Empresas, São Paulo, v.42, n.1, p.36-49, jan./mar.

LAWLER III, E.E. (1995) From job-based to competency-based organizations. Journal of Organizational Behaviors, v.15, p.3-15.

LE BORTEF, G. (1995). De la competence. Editions D’Organizations.

LEIFER, R.; O'CONNOR, G.C.; RICE, M. (2002). A implementação de inovação radical em empresas maduras. Revista de Administração de Empresas, São Paulo, v.42, n.2, p.1730 , abr./jun. 
MARRAS, J.P. (2000). Administração de recursos humanos. São Paulo: Futura.

MARTINS, R.A. (1999) Sistemas de medição de desempenho: um modelo para estruturação do uso. 248p. Tese (Doutorado) - Escola Politécnica, Universidade de São Paulo, São Paulo. 1999.

MESHOULAM, I.; BAIRD, L. (1987). Proactive human resource management. Human Resource Management, v. 26, n. 4, p. 483-502, Winter.

MINTZBERG, H. (1995). Criando organizações eficazes: estruturas em cinco configurações. São Paulo: Atlas.

MORGAN, G. (1996). Imagens da organização. São Paulo: Atlas.

NADER, R.M., GUIMARÃES, T.A., RAMAGEM, S.P. (1998). Da avaliação para a gestão do desempenho individual: a implantação de uma metodologia baseada no planejamento empresarial. Brasília: Escola Nacional de Administração Pública.

NADLER, D.A., TUSHMAN, M.L. (1994). Projetos de organização com boa adequação. In: NADLER, D.A. et al. Arquitetura organizacional. Rio de Janeiro: Campus.

PARKER, K.H.; DE BONIS, D.F.; ABUD, M.R. (1997). Introdução ao estudo da administração. São Paulo: Pioneira.

PARRY, S. B. (1996). The quest for competencies. Training and Development. July. 
PFEFFER, J. (1994). Vantagem competitiva através de pessoas. São Paulo: Makron.

PRUSAK, L.; COHEN, D. (2001). How to invest in social capital. Harvard Business Review, v.79, n. 6, p. 86-93, june.

RAMOS, M. N. (2001). A pedagogia das competências: autonomia ou adaptação? São Paulo: Cortez.

REIS, G.G. (2000). Avaliação 360 graus: um instrumento de desenvolvimento gerencial. São Paulo: Atlas.

RODRIGUES, C.H.C.; SANTOS, F.C.A. (2001). Empowerment: ciclo de implementação, dimensões e tipologia. Gestão e Produção, v. 8, n. 3, p. 237-249, dez.

SANTOS, F.C.A. (1999). Estratégia de recursos humanos: dimensões competitivas. São Paulo: Atlas.

SANTOS, F.C.A. (1998). Dimensões competitivas da estratégia de recursos humanos :importância para a gestão de negócios em empresas manufatureiras. 302 p. + anexos. Tese (Doutorado). Escola de Administração de Empresas de São Paulo, Fundação Getúlio Vargas, São Paulo, 1998.

SCHULER, R.S.; JACKSON, S.E. (1995). Linking competitive strategies with human resource management. In: MINER, J.B.; CRANE, D.P. (Coords.) Advances in the practice, theory and research of strategic human resource management. New York: Harper Collins. p.20-40. 
SENGE, P. (1990) A quinta disciplina. São Paulo: Best Seller.

SENTANIN, F.S. (2003). A gestão por processos dentro do planejamento estratégico de uma empresa de P\&D. . In: ENCONTRO NACIONAL DE ENGENHARIA DE PRODUÇÃO, 23., 2003, Ouro Preto. Anais..., Universidade Federal de Ouro Preto, 2003.

SLACK, N. et al. (1997). Administração da Produção. São Paulo: Atlas.

SVEIBY, K. E. (1998). A nova riqueza das organizações: gerenciando e avaliando patrimônios de conhecimento. Rio de Janeiro: Campus.

TAYLOR, F.W. (1916). The principles of scientific management. New York and London: Harper \& Brothers.

UBEDA, C.L.; SANTOS, F.C.A. (2002). Gestão de desempenho por competências como elemento viabilizador das estratégias de recursos humanos e de produção. In: ENCONTRO NACIONAL DE ENGENHARIA DE PRODUÇÃO, 22., 2002, Curitiba. Anais..., Porto Alegre, ABEPRO.

WOOD JUNIOR, T. (Coord.) (1995). Mudança organizacional: aprofundando temas atuais em administração de empresas. São Paulo: Atlas.

ZARIFIAN, P. (2001). Objetivo competência: por uma nova lógica. São Paulo: Atlas. 
ANEXO A - Questões utilizadas no estudo de caso 
Questões utilizadas no estudo de caso:

Quais competências são importantes para a EMBRAPA?

$>$ Quais são os principais problemas que a EMBRAPA está enfrentando atualmente e que precisa resolver?

$>$ Quais são os principais projetos de inovação que a EMBRAPA está planejando e executando atualmente?

$>$ Como a EMBRAPA está desenvolvendo as competências necessárias relativas aos principais problemas e projetos de inovação?

$>$ Como a EMBRAPA pretende medir os resultados do desenvolvimento dessas competências?

$>$ A estrutura atual da EMBRAPA dificulta a gestão de competências? Em que aspectos?

> Há algum projeto específico da EMBRAPA sobre Gestão de Competências e Desempenho? E se tem o conhecimento de todos os funcionários?

$>$ Os funcionários têm conhecimento da importância da avaliação de desempenho tanto para a instituição quanto para os próprios funcionários?

> Há um processo estruturado de gestão de desempenho pessoal na empresa? Qual a periodicidade da avaliação de desempenho?

$>$ Como o processo de avaliação de desempenho está associado à gestão de competências?

Quem são os responsáveis pelo planejamento e pela avaliação dos resultados tanto da gestão de competências como da gestão do desempenho? 
ANEXO B - Os Agrupamentos do SAAD-RH da Embrapa Pecuária Sudeste 
Os Agrupamentos do SAAD-RH da Embrapa Pecuária Sudeste:

> Agrupamento A: composto por supervisores e responsáveis de setores específicos, avaliados por dois Chefes - Adjuntos;

Agrupamento B: composto por treze empregados do campo responsável pelo gado de leite e gado de corte, avaliados por dois supervisores;

$>$ Agrupamento C: composto pelo pessoal do apoio estratégico, vinte e cinco empregados, avaliados por dois supervisores;

Agrupamento D: composto pelo pessoal de serviços auxiliares, onze empregados, avaliados por dois supervisores;

Agrupamento E: composto pelo pessoal técnico de nível superior, seis empregados, avaliados por quatro supervisores;

Agrupamento G: composto pelo três chefes adjuntos, avaliados pelo Chefe Geral da Unidade;

Agrupamento Científico: composto por vinte pesquisadores, avaliados pelo Chefe Adjunto de Pesquisa e Desenvolvimento;

> Agrupamento H: composto pelo pessoal administrativo, vinte e sete empregados, avaliados por nove supervisores;

Demitidos:

Afastados: composto por 6 pessoas, avaliados por Chefes de Área;

Pós-graduação: composto por três empregados (afastados de suas atividades). 
ANEXO C - Formulário PARTI - Planejamento, Acompanhamento e Avaliação de Resultados do Trabalho Individual. 
Campos do PARTI a serem preenchidos

Campo 1 - Período da Avaliação (anual)

Campo 2 - Identificação do Empregado: nome, cargo (efetivo, gerencial ou de supervisão), função, número de matrícula na Embrapa, unidade de lotação e área/setor em que o empregado trabalha.

Campo 3 - Plano de Trabalho e Itens de Avaliação

a) Atividade: no momento do planejamento, supervisor e empregado discutem as atividades a serem incluídas no plano de trabalho. A descrição da atividade orienta o processo de execução do trabalho.

Ao descrever uma atividade, deve-se considerar o conjunto de ações necessárias para a execução de um processo que resulta num produto ou serviço. A descrição não deve ser exagerada, nem vaga. Indicar o que se espera e como seja feito. Verbo de AçãoComprometimento (EMBRAPA, SAAD-RH Passo a Passo, 1997).

b) Resultado Esperado: produto final a ser desenvolvido

Plano de ação ou subprojeto: à frente de cada atividade, deve ser indicado o número do plano de ação ou subprojeto ao qual a atividade está vinculada.

Índices do PARTI:

PPA- (Peso por Atividade) - quando estiver sendo elaborado o plano de trabalho, supervisor e empregado devem discutir o PPA. Representa a importância de cada atividade planejada em relação às demais, considerando a complexidade, o tempo dispendido, 
prioridade, etc. A soma do PPA de todas as atividades listadas no PARTI deve totalizar $100 \%$.

NIA (Nível de Impacto por Atividade) - representa o nível de relevância da atividade para o alcance das metas e dos objetivos da unidade, considerando-se a categoria funcional do empregado. Para o grupo ocupacional técnico-científico, o NIA pode ser definido com base no conjunto de indicadores usados no Modelo de Análise de Produtividade e Eficiência Relativa das Unidades Descentralizadas. Exs:

produção técnico-científica (artigos científicos, capítulos de livro, artigos de congresso, resumos, orientação de dissertações e teses);

geração de tecnologias e conhecimentos (boletim de $\mathrm{P} \& \mathrm{D}$, circular técnica, comunicado técnico, etc);

transferência de tecnologia e difusão de imagem (cursos, dias de campo, palestras, orientação de estagiários, etc);

$>$ desenvolvimento de tecnologias, produtos e processos (práticas agropecuárias, metodologias, recomendação de cultivares, etc).

A definição dos indicadores e dos valores dos níveis de impacto das atividades começa pela identificação das atividades constantes do Plano Anual de Trabalho, num determinado período, e as metas e os objetivos da unidade. Quando for possível relacionar uma atividade que o empregado faz com as metas específicas da unidade, define-se o NIA considerando-se as atribuições que caracterizam o cargo.

NFM - Nível de Fornecimento de Meios - por meio desse índice o supervisor se certifica de que estão sendo oferecidos, ao empregado, as orientações e os meios necessários à execução das atividades planejadas (RH, materiais, financeiros, conhecimento e informação). Para efeito de avaliação de cada atividade planejada, o NFM será fixado em $90 \%$. 
NOR - Nível de Obtenção de resultados - avalia cada atividade prevista no plano de trabalho na escala de 0 a 100. O supervisor, em conjunto com o empregado, deve avaliar o NOR.

Campo 4 - Plano de desenvolvimento do empregado

Verifica a necessidade de desenvolvimento, treinamento para desenvolver novas habilidades e conhecimentos ou aperfeiçoá-los.

Pode ser feito mediante a leitura de manuais, estágio em serviço na Empresa ou fora dela, participação em treinamentos, reuniões e encontros técnico-científicos.

Campo 5 - Comentários Gerais do Empregado

Feito no momento em que desejar, indicar ou opinar sobre alguma circunstância que tenha influenciado seus resultados.

Campo 6 - Comentários Gerais do Supervisor

Fato que tenha alterado o cumprimento de alguma atividade planejada. Devem ser justificadas. AI (atividade interrompida) e/ou AC (atividade cancelada).

Campo 7 - Resultado da avaliação

EAF Escore de Avaliação Final

$\mathrm{EAF}=\left(\mathrm{IRA}^{*} 0,60\right)+(\operatorname{IMPr} * 0,40)$ 
ANEXO D - Atividades do SAAD - Pesquisador e Nível de Impacto da Atividade (NIA), válidas para o ano de 2003 


\section{ATIVIDADES DO SAAD DO PESQUISADOR E NÍVEL DE IMPACTO DA ATIVIDADE (NIA)}

\section{1) ATIVIDADES RELACIONADAS COM SEP e PAT.}

Obs.: Na avaliação do responsável pelo subprojeto ou plano de ação poderá ser ouvido o líder do projeto, se este for do CPPSE, e, no caso dos membros, o responsável pelo subprojeto ou plano de ação.

1.1) ATIVIDADE: Participar da elaboração de PLANO DE AÇÃO (descrever), de acordo com as normas do SEG, no prazo estabelecido pelo CTI. $(\mathrm{NIA}(=50)$

RESULTADO ESPERADO: Plano de ação apresentado ou reapresentado ao CTI, no(s) prazo(s) estipulado(s).

1.2) ATIVIDADE: Participar da elaboração de PRÉ-PROPOSTA ou PROPOSTA de Edital da Embrapa (descrever), de acordo com as normas do SEG, no prazo estabelecido pelo CTI. (NIA $=80$ )

RESULTADO ESPERADO: Projeto apresentado ou reapresentado ao CTI no(s) prazo(s) estipulado(s).

1.3) ATIVIDADE: Exercer a responsabilidade por SUBPROJETO ou PLANO DE AÇÂO (NIA = 80)

RESULTADO ESPERADO: Descrever resultado(s) esperado(s), meta(s) prevista(s) e ou ação(ões) a ser(em) executada(s). Obs.: 1) Inclui relatório do subprojeto ou plano de ação (SEG, PAT, outros), com atendimento de prazos estabelecidos; 2) Resultados previstos e obtidos e metas previstas e alcançadas deverão ser informadas para inclusão no PAT e nos Relatórios do PAT, nos prazos estabelecidos. 3) Ver observação ${ }^{\circ}{ }^{\circ}$, na página 4.

1.4. ATIVIDADE: Participar da execução de SUBPROJETO ou PLANO DE AÇÃO como membro (inclui o responsável pelo subprojeto ou pelo plano de ação) ou colaborador. NIA = percentagem de participação no subprojeto ou plano de ação $\rightarrow$ valor máximo $=100$ ).

RESULTADO ESPERADO: Descrever resultado(s) esperado(s), meta(s) prevista(s) e ou ação(ões) a ser(em) executada(s). Obs.: Ver observação ${ }^{\circ} 8$, na página 4.

1.5. ATIVIDADE: Acompanhar a execução de PROJETO. (NIA =50)

RESULTADO ESPERADO: Descrever resultado(s) esperado(s), meta(s) prevista(s) e ou ação(ões) a ser(em) executada(s). Obs.: Inclui relatórios e gestão do projeto (Somente o Líder de Projeto terá esta atividade).

2) ATIVIDADES RELACIONADAS À PRODUÇÃO DE PUBLICAÇÕES, À TRANSFERÊNCIA DE TECNOLOGIA E PROMOÇÃO DA IMAGEM E AO DESENVOLVIMENTO DE TECNOLOGIAS, PRODUTOS E PROCESSOS.

2.1) ATIVIDADE: Elaborar e submeter ARTIGO CIENTÍFICO ou CAPÍTULO DE LIVRO (indicar data e especificar título ou assunto, nome do periódico ou título do livro, conforme o caso) (NIA: NACIONAL $=40$; ESTRANGEIRO $=50$ )

RESULTADO ESPERADO: Artigo científico ou capítulo de livro redigido e submetido ao periódico, ao editor do livro ou ao Comitê Local de Publicações (CLP), no prazo indicado.

2.2) ATIVIDADE: Publicar ARTIGO CIENTÍFICO ou CAPÍTULO DE LIVRO (especificar síntese da referência bibliográfica: título do artigo ou capítulo, nome do periódico ou título do livro, volume, páginas, ano) (NIA: NACIONAL $=40$; ESTRANGEIRO $=50$ )

RESULTADO ESPERADO: Artigo científico ou capítulo de livro publicado. Obs.: Esta atividade não se aplica se o artigo ou o capítulo já houver sido contemplado anteriormente com a pontuação integral, i.e., NIA $=80$ para artigo em periódico nacional e NIA $=100$ para artigo em periódico estrangeiro.

2.3) ATIVIDADE: Elaborar e submeter SISTEMA DE PRODUÇÃO (indicar data e especificar título ou assunto) (NIA $=60)$

RESULTADO ESPERADO: Sistema de produção redigido e submetido ao Comitê Local de Publicações (CLP), no prazo indicado. 
2.4) ATIVIDADE: Elaborar e submeter ARTIGO DE ANAIS, NOTA TÉCNICA, BOLETIM DE PESQUISA, CIRCULAR TÉCNICA, DOCUMENTO, RECOMENDAÇÃO OU INSTRUÇÃO TÉCNICA, ARTIGO DE DIVULGAÇÃO ou ROTEIRO PARA VÍDEO (indicar título ou assunto e prazo de entrega) (NIA: NACIONAL $=32 ;$ ESTRANGEIRO $=40$ )

RESULTADO ESPERADO: Artigo de anais, nota técnica, boletim de pesquisa, circular técnica, documento, recomendação ou instrução técnica, artigo de divulgação ou roteiro para vídeo apresentado ao editor ou ao Comitê Local de Publicações no prazo indicado. Obs.: 1) trabalhos com a estrutura e a dimensão daqueles da Reunião Anual da SBZ (resumo, abstract, introdução, material e métodos, conclusões e referências bibliográficas) são considerados "Artigos de Anais"; 2) Artigo de Divulgação = artigo em revista de divulgação (p. ex., Balde Branco, DBO Rural, Pecuária de Corte).

2.5) ATIVIDADE: Elaborar e submeter RESUMO para Reunião, Congresso, Simpósio ou similar, NOTA PRÉVIA, COMUNICADO TÉCNICO, OU FOLDER (indicar evento e periódico, conforme o caso, título ou assunto e data) (NIA: NACIONAL $=16$; ESTRANGEIRO $=20$ )

RESULTADO ESPERADO: Resumo, nota prévia, comunicado técnico ou folder apresentado ao editor ou ao Comitê Local de Publicações no prazo indicado.

2.6) ATIVIDADE: Editar LIVRO (indicar título ou assunto e data) (NIA: NACIONAL = 80; ESTRANGEIRO $=100)$.

RESULTADO ESPERADO: Livro editado na data prevista.

2.7) ATIVIDADE: Editar ANAIS, RELATÓRIO TÉCNICO ANUAL ou outras publicações (indicar título ou assunto e data) (NIA: NACIONAL $=32$; ESTRANGEIRO $=40$ ).

RESULTADO ESPERADO: Anais ou publicação editados na data prevista.

2.8) ATIVIDADE: Apresentar PALESTRA, CONFERÊNCIA, SEMINÁRIO INTERNO ou AULA DE CURSO INTERNO (teórica ou prática; ver item 2.10, que se refere a pós-graduação) (indicar título ou assunto e data) (NIA $=10)$.

RESULTADO ESPERADO: Palestra, Conferência, Seminário ou aula apresentada na data prevista.

2.9) ATIVIDADE: Participar de COMISSÃO ORGANIZADORA de dia-de-campo, curso (ver item 2.10), reunião, estande ou feira ou exposição, etc., designada por memorando ou ordem de serviço (especificar o EVENTO e indicar a data) (NIA $=8)$.

RESULTADO ESPERADO: Evento realizado, na data prevista.

2.10) ATIVIDADE: Participar de COMISSÃO ORGANIZADORA de curso de nível de especialização ou pós-graduação, simpósio, "workshop" ou leilão de bovinos do CPPSE, designada por memorando ou ordem de serviço (especificar o EVENTO e indicar a data) $(\mathrm{NIA}=25)$

RESULTADO ESPERADO: Evento realizado, na data prevista.

2.11) ATIVIDADE: Atender visitante(s) (NIA = 4). Obs.: 1) Inclui visitantes individuais e de grupos; 2) Registrar as visitas atendidas (data, nome, assunto); 3) Será computada a ação do atendimento, não o n ${ }^{\circ}$ de visitantes atendidos, mas o $\mathrm{n}^{\circ}$ de visitantes deve ser anotado, assim como "o que" foi tratado, com "quem" e "quando".

RESULTADO ESPERADO: Atendimento realizado.

02.12) ATIVIDADE: Atender CONSULTA TÉCNICA, por carta, correio eletrônico ou telefone (NIA = 1). RESULTADO ESPERADO: Atendimento executado. Obs.: Registrar as consultas (data, nome, assunto).

2.13) ATIVIDADE: Ministrar disciplina em CURSO de pós-graduação, previsto em convênio de cooperação técnica (quantificar e indicar local e período), aulas em curso interno de nível equivalente (NIA proporcional ao $\mathrm{n}^{\circ}$ de horas: até 20 horas, NIA $=25$; até 40 horas, NIA $=50$; mais de 40 horas, NIA $=75$ ).

RESULTADO ESPERADO: Disciplina ou aulas ministradas como previsto.

2.14) ATIVIDADE: APRESENTAR TRABALHO (oral ou pôster) em Reunião, Congresso, Simpósio ou similar (indicar evento e data) (NIA: NACIONAL $=4$; ESTRANGEIRO $=5$ ). 
RESULTADO ESPERADO: Trabalho apresentado na data prevista.

\subsection{5) ATIVIDADE: ORIENTAR OU CO-ORIENTAR}

ESTAGIÁRIO DE NÍVEL MÉDIO, sem monografia (NIA: Orientador $=4$ ),

ESTAGIÁRIO DE NÍVEL MÉDIO, com monografia (NIA: Orientador $=8$ ),

ESTAGIÁRIO DE NÍVEL SUPERIOR, sem monografia (NIA: Orientador $=8$ ),

ESTAGIÁRIO DE NÍVEL SUPERIOR, com monografia (NIA: Orientador $=16$; Co-Orientador $=8$ ),

BOLSISTA DE APOIO TÉCNICO (NIA = 8),

BOLSISTA DE INICIAÇÃO CIENTÍFICA (NIA: Orientador $=16$; Co-Orientador $=8$ ),

BOLSISTA DE APERFEIÇOAMENTO (NIA: Orientador $=24$; Co-Orientador $=12$ ),

BOLSISTA DE MESTRADO (NIA: Orientador $=56$; Co-Orientador $=28$ ),

BOLSISTA DE DOUTORADO (NIA:Orientador $=80$; Co-Orientador $=40$ ) ou

BOLSISTA RECÉM-DOUTOR OU PÓS-DOUTORADO (NIA: Orientador $=40 ;$ Co-Orientador $=20$ )

(informar nome do estagiário ou bolsista e duração do estágio).

RESULTADO ESPERADO: Estagiário ou bolsista orientado no período indicado.

Obs.: Inclui todas as atividades relacionadas à atividade, tais como elaboração de monografia, tese, dissertação, pedido de bolsa e relatórios.

2.16) ATIVIDADE: Coordenar ou colaborar em UNIDADE DEMONSTRATIVA ou UNIDADE DE OBSERVAÇÃO (indicar unidade e período) (NIA = 25)

RESULTADO ESPERADO: Unidade Demonstrativa ou de Observação coordenada ou acompanhada.

Obs.: Na avaliação do colaborador poderá ser ouvido o coordenador.

2.17) ATIVIDADE: Desenvolver, de acordo com os indicadores do SAL descritos no glossário da Norma 037.01.06.01.5.001, publicada no BCA n ${ }^{\circ}$ 42, de 26.9.2001:

- CULTIVAR GERADA E LANÇADA OU RAÇA E TIPO

- CULTIVAR TESTADA E RECOMENDADA

- PRÁTICA OU PROCESSO AGROPECUÁRIO

NIA $=200$

- METODOLOGIA CIENTÍFICA

- OUTROS INDICADORES (TECNOL., PROD. ou PROC.) DESCRITOS NO GLOSSÁRIO NIA = 50.

Obs.: O pesquisador deverá entregar texto descritivo (impresso e em arquivo eletrônico), acompanhado da respectiva publicação que suporte a comprovação para o Relatório do PAT (não pode ser resumo). O texto descritivo deve conter o nome da tecnologia, do produto ou do processo, o nome dos parceiros, sua descrição sucinta e objetiva, seu público-alvo, seus impactos esperados (positivos, negativos) e suas vantagens em relação a similares, sem informar como a tecnologia, o produto ou o processo foi desenvolvido. Os co-autores serão indicados pelo autor principal. Em caso de dúvida, a proposta será analisada pelo CTI.

RESULTADO ESPERADO: Tecnologia, produto ou processo desenvolvido e publicado.

\section{3) OUTRAS ATIVIDADES}

3.1) ATIVIDADE: Participar de COMITÊ ou COMISSÃO PERMANENTE (especificar). (NIA: CTI = 80; CLP, PAT, Qualidade, CLPI, Biossegurança, CIPA, Alienação de Animais, Comitê Assessor do CNPq, Outras comissões internas ou externas $=40$ ).

RESULTADO ESPERADO: Participação nas reuniões ou atividades realizadas e atendimento das solicitações do Presidente do Comitê ou Comissão ou da Chefia.

3.2) ATIVIDADE: Participar em Comissão Temporária de avaliação de trabalhos científicos (p.ex., Comissão Científica da Reunião Anual da SBZ, de projetos (p.ex., Premiação Nacional de Equipes da Embrapa, projetos do CNPq ou de fundação estadual de fomento) e similares. NIA = 10/dia.

RESULTADO ESPERADO: Participação na comissão.

3.3) ATIVIDADE: Exercer a responsabilidade por e executar AÇÃO DE SUPORTE À PESQUISA (ESPECIFICAR) $($ NIA $=100)$.

RESULTADO ESPERADO: Execução das atividades pertinentes.

Obs.: Responsabilidade atribuída por Portaria, Ordem de Serviço, Instrução de serviço ou Memorando Interno. 
2.4)ATIVIDADE: Elaborar proposta (projeto) de CAPTAÇÃO DE RECURSOS para instituição financiadora ou programa de fomento (p. ex., FAPESP, CNPq, RHAE, PRODETAB, SEBRAE) e apresentar ao CTI ou à Chefia do CPPSE (indicar valor, assunto, instituição ou programa e prazo de apresentação; incluir pagamento de despesas de viagem para palestra - nesse caso, considerar o total desses pagamentos).

$$
\text { até } \mathrm{R} \$ 10.000,00-\mathrm{NIA}=2, \quad \mathrm{R} \$ 10.001,00 \text { a } \mathrm{R} \$ 20.000,00-\mathrm{NIA}=5 \text {, }
$$

$\mathrm{R} \$ 20.001,00$ a $\mathrm{R} \$ 30.000 .00-\mathrm{NIA}=10, \quad \mathrm{R} \$ 30.001,00$ a $\mathrm{R} \$ 40.000,00-\mathrm{NIA}=15$,

$\mathrm{R} \$ 40.001,00$ a $\mathrm{R} \$ 50.000 .00-\mathrm{NIA}=20, \quad \mathrm{R} \$ 50.001,00$ a $\mathrm{R} \$ 60.000 .00-\mathrm{NIA}=25$,

$\mathrm{R} \$ 60.001,00$ a $\mathrm{R} \$ 70.000 .00-\mathrm{NIA}=30, \quad \mathrm{R} \$ 70.001,00$ a $\mathrm{R} \$ 80.000 .00-\mathrm{NIA}=35$,

$\mathrm{R} \$ 80.001,00$ a $\mathrm{R} \$ 90.000 .00-\mathrm{NIA}=40, \quad \mathrm{R} \$ 90.001,00$ a $\mathrm{R} \$ 100.000 .00-\mathrm{NIA}=45$,

$>\mathrm{R} \$ 100.000 .00-\mathrm{NIA}=50$

RESULTADO ESPERADO: Proposta apresentada e, se aprovada, enviada dentro do prazo.

Obs.: O responsável pela proposta indicará os nomes dos pesquisadores que efetivamente participaram da elaboração. Quando a proposta for de várias unidades ou instituições, vale o valor destinado ao CPPSE.

3.5) ATIVIDADE: Apresentar Relatório Técnico e ou de Prestação de Contas de CAPTAÇÃO DE RECURSOS, a instituição ou programa de fomento, no prazo estipulado pela instituição ou programa (indicar valor, assunto e instituição ou programa e prazo). até $\mathrm{R} \$ 10.000,00-\mathrm{NIA}=5$, $\mathrm{R} \$ 20.001,00$ a $\mathrm{R} \$ 30.000 .00-\mathrm{NIA}=20$, $\mathrm{R} \$ 40.001,00$ a $\mathrm{R} \$ 50.000 .00-\mathrm{NIA}=40$, $\mathrm{R} \$ 60.001,00$ a $\mathrm{R} \$ 70.000 .00-\mathrm{NIA}=60$, $\mathrm{R} \$ 80.001,00$ a $\mathrm{R} \$ 90.000 .00-\mathrm{NIA}=80$, $>\mathrm{R} \$ 100.000 .00-\mathrm{NIA}=100$
$\mathrm{R} \$ 10.001,00$ a $\mathrm{R} \$ 20.000,00-\mathrm{NIA}=10$, $\mathrm{R} \$ 30.001,00$ a $\mathrm{R} \$ 40.000,00-\mathrm{NIA}=30$, $\mathrm{R} \$ 50.001,00$ a R $\$ \quad 60.000 .00-\mathrm{NIA}=50$, $\mathrm{R} \$ 70.001,00$ a R $\$ 80.000 .00-\mathrm{NIA}=70$, $\mathrm{R} \$ 90.001,00$ a $\mathrm{R} \$ 100.000 .00-\mathrm{NIA}=90$,

RESULTADO ESPERADO: Relatório enviado no prazo indicado.

Obs.: O responsável pela proposta indicará os nomes dos pesquisadores que efetivamente participaram da elaboração. Válido para cada relatório, independentemente da periodicidade anual. Quando o relatório é parcial, vale o valor a que se refere a prestação de contas.

3.6) ATIVIDADE: Participar de BANCA EXAMINADORA, atender CONSULTORIA AD HOC, emitir PARECER, conceder ENTREVISTA (NIA $=10$ )

RESULTADO ESPERADO: Atendimento da solicitação.

Exemplos: Parecer sobre o artigo científico para editoria de periódico, sobre trabalho para CLP, sobre projeto para o CTI; Consultoria para FAPESP ou CNPq.

3.7) ATIVIDADE: Atender SOLICITAÇÕES DA CHEFIA. (Participar em comissão administrativa temporária; elaborar documento; participar em estande de feira ou exposição; exercer a função de Conselheiro Acadêmico; atender outra atividade eventual) (NIA =5).

RESULTADO ESPERADO: Atendimento da solicitação.

Obs.: Se implicar prejuízo na execução de outras atividades previstas, o PARTI deve ser negociado.

3.8) ATIVIDADE: Participar de MESA REDONDA ou atividade similar, como presidente, coordenador, debatedor, moderador, membro, etc. $(\mathrm{NIA}=10)$.

RESULTADO ESPERADO: Execução das atividades pertinentes.

Observações:

1) No preenchimento do PARTI do SAAD, seguir o enunciado das atividades desta relação. Outras atividades não descritas na relação deverão ser " negociadas", para determinação do NIA.

2) A descrição das atividades deve ser sintética, o suficiente para sua identificação ou compreensão.

3) Atender solicitação de reformulação faz parte da elaboração do trabalho.

4) Para cada ação, trabalho ou evento, relacionar uma atividade no PARTI, exceto atividade com NIA igual a até 10 . 
5) Para inclusão da atividade no PARTI, deve ser atendida a definição dos indicadores, de acordo com o "Glossário" do Sistema de Avaliação de Unidades - SAU.

6) Para publicações, o NIA de autor e co-autor será igual.

7) Não haverá limitação do número de atividades.

8) Exemplos das atividades 1.3 e 1.4

8.1) Responsável por cinco subprojetos ou planos de ação:

Atividade

Exercer resp. subp. "a"

Exercer resp. subp. "b"

Exercer resp. subp. "c"

Exercer resp. subp. "d"

Exercer resp. subp. "e"

Part. exec. subp. "a"

Part. exec. subp. "b"

Part. exec. subp. "c"

Part. exec. subp. "d"

Part. exec. subp. "e"

Soma
Item

1.3

1.3

1.3

1.3

1.3

1.4

1.4

1.4

1.4

1.4
Part. No Subprojeto

20
20
20
20
20
100

NIA

80

80

80

80

80

20

20

20

20

20

500

8.2) Responsável por um subprojeto ou plano de ação e participação em "n" outros subprojetos ou planos de ação:

Atividade

Exercer resp. subp. "a"

Part. exec. subp. "a"

Part. exec. subp. "n1, n2, n3"

Soma

\section{Item}

1.3

1.4

1.4
Part. No Subprojeto

40

60

100
NIA

80

40

60

180 